\title{
WALTON AND THE
}

\section{EARLIER FISHING WRITERS}




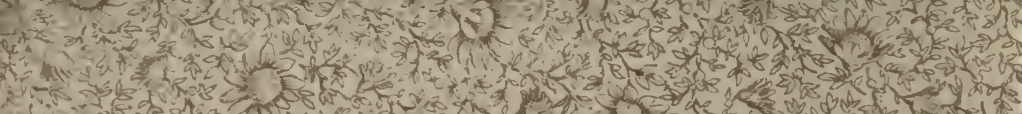

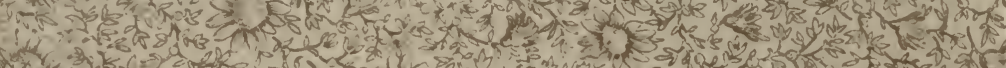
2. a

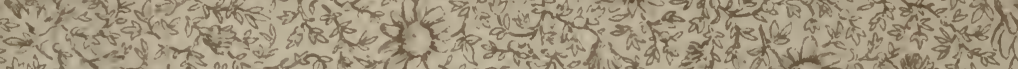
sys)

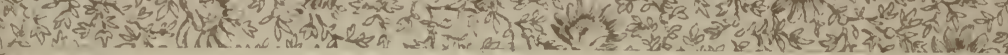

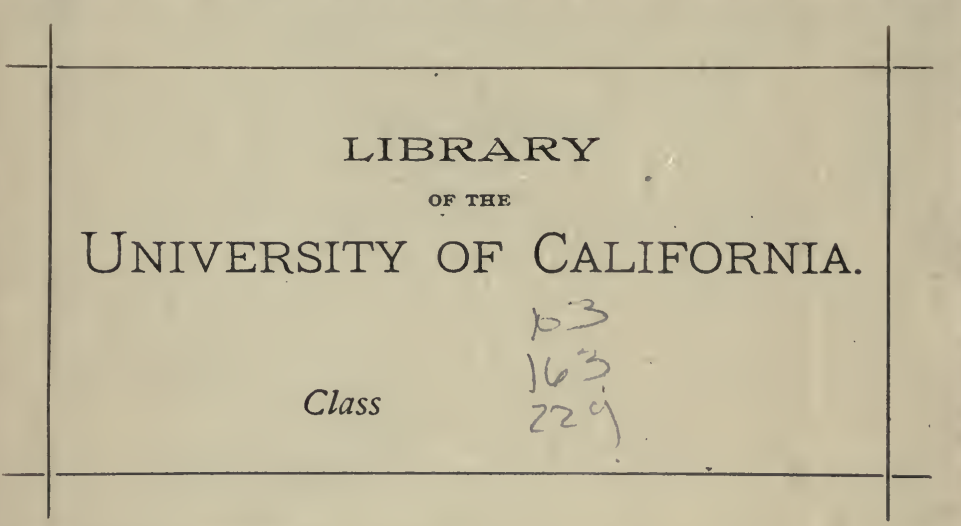

P

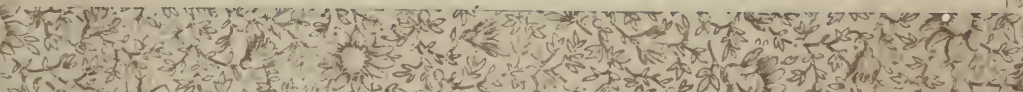

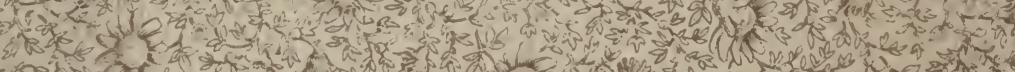

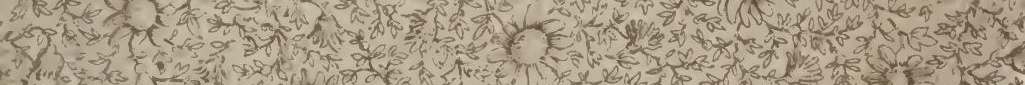

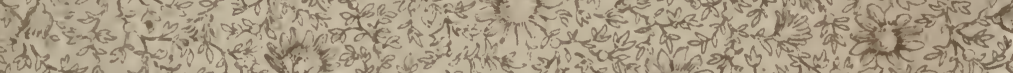

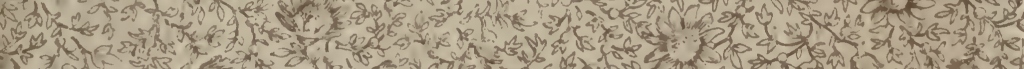
fever whe

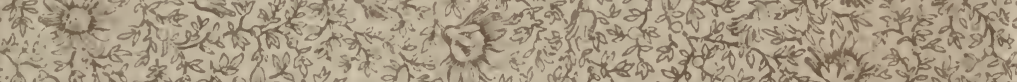

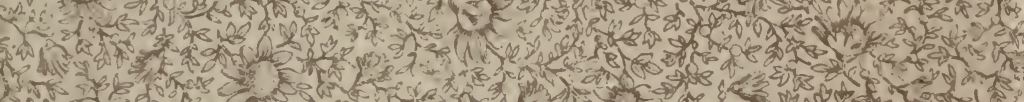

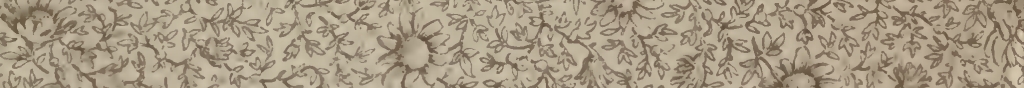

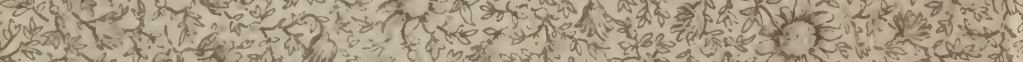
1) 1 a

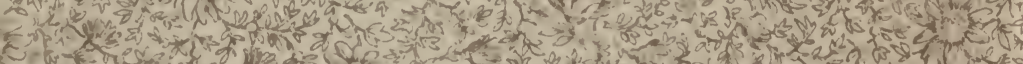

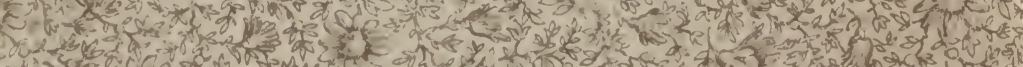

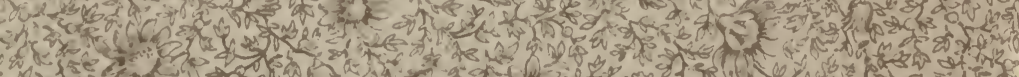

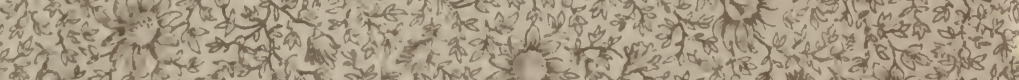

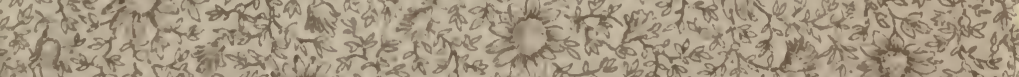

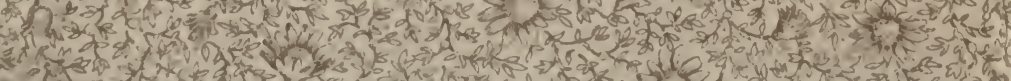
की

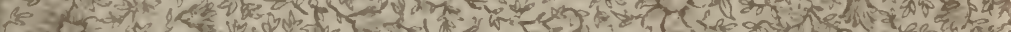






\section{The Book-Lover's Library.}

Edited by

Henry B. Wheatley, F.S.A. 


\title{
W A L T O N
}

AND

SOME EARLIER WRITERS ON

\section{FISH AND FISHING}

\author{
BY \\ R. B. MARSTON \\ Editor of "The Fishing Gazette" : Honorary Treasurer of \\ the Fly-Fishers' Clisb
}

"Companionable books, that tempt us out of doors and keep us there."-JAMEs Russeli Lowell

\section{LONDON}

ELLIOT STOCK, 62, PATERNOSTER ROW 1894

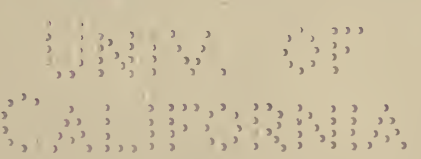


SH435

M3 
$\tau_{0}$

M Y FATHER,

“THE AMATEUR ANGLER,"

I DEDicate THIS LITTLE Book

IN REMEMBRANCE OF

DELIGHTFUL FISHING DAYS WITH HIM,

EXTENDING OVER MORE THAN

THIRTY YEARS.

\section{6}


Digitized by the Internet Archive in 2007 with funding from Microsoft Corporation 


\section{INTRODUCTORY.}

AVE you read "The Compleat
Angler"? If you have, and
are also acquainted with the Author's other writings, then these pages may perchance refresh your remembrance of them; but their object and the hope of the writer is to make Walton and a few earlier angling writers known to some to whom they are only names.

Looking back through a life, a neverfailing delight of which has been the devouring of books, I confess that not many have had such an enduring charm for me as those of Walton. His "Compleat Angler" is the first book I can remember reading. I have the vii 
edition before me now, one of those productions of the Chiswick Press, published in 1863 by Bell \&o Daldy and Sampson Low \&o Co.; and though I have seen nearly all of the hundred or more reprints of the "Angler," and possess most of the best, this little half-bound, well-worn edition will always be among those most prized.

I must have been born with a love of angling. I certainly caught Prussian carp in an old pond near to Craven Arms in Shropshire long before I could read. As a youngster of ten years $I$ remember one wet day wondering whether any in that row of small books on the top shelf of a book-case in my father's library were interesting. Within reach were rows of Scott in green cloth with white labels; big volumes of Knight's "History of England"; then a regiment of Shakespeare in red; above them a charming American edition of Dickens in green cloth, published, I think, by Ticknor, Fields, \&o Osgood. These and 
many others were to be a discovery later on. Who can forget the first coming under the spell of the Wizard of the North, or of Dickens, the Wizard of the South? To me, then, these were only repellent by reason of their big battalions. But away above them was this row of little books. I could just read the titles of some from the floor. I remember Southey's "Nelson," White's "Selborne," George Herbert's "Poems," Milton's "Paradise Lost." These did not appeal much to a schoolboy's idea of books to read. But suddenly I noticed in gold letters the word "Angler," and from the top of a chair I saw the full title was "Walton and Cotton's Complete Angler." By George! perhaps that's about fishing, I thought; and stepping from the chair on to the smooth, rounded, mahogany cover of the writing-desk which formed the lower half of the book-case, I clutched the little volume, and then came down with a crash on the floor. It was some little time before I felt equal to opening. 
my find; but when I did, and found I had got three hundred pages about fish and rivers and ponds, I forgot my bumps, I forgot everything as I listened to the voice of the dear old Master. If I had only studied my school-books as I did Walton! I remember some years after, one hot summer day, when my old schoolmaster, the Rev. Mr. H-, was perspiring with the heat and his endeavour to make some lines of Xenophon's "Anabasis" clear to a fat Irish boy, that, thinking his attention would be engaged for some time, I propped up the lid of my desk as a screen, and was soon deep in dearly beloved Walton. The loud voice of the master and the hesitating answers of the boy soon faded away, and I was watching Piscator kill that big chub with the white spot on his tail, when bang went the master's cane on his oak desk. I looked round my sheltering desk-lid only to find, in perfect silence, the whole eyes of the class on me, and then, with Xenophon upraised in 
hand ready to hurl at my head, came the thundering "Marston! what book have you got there?" Prepared at any moment to avoid Xenophon by a judicious "duck down," I said, "Please, sir, it's Walton's 'Complete Angler.'” "Walton's 'Angler,' " repeated the master, and a pleasant change came over the flushed and angry but always jolly face. "Come up here, sir, and let me look at it." I went up with some misgivings, for the four-foot cane was not put down with Xenophon; in fact, "old H___," as we irreverently called him, seemed to be trying its balance as he would a fly-rod. "Ah! a very pretty edition"; and after some little time, "And are you a fisherman?" I proudly said I was; and then we had a regular talk about fishing, and $I$ related how during the recent holidays I had lost a five-pound chub. "What, sir! How do you know he was five pounds, if you lost him?" "Well, sir, I think -I believe he would have weighed near six, if I had caught him." "That will 
do, sir"; and with, as I thought, a halfsuppressed twinkle in his eye, "Don't let me catch you again." After school, when we were talking about my escape, some of the fellows said, "Didn't you know he was a fisherman? Well, if you want a holiday any time, tell him you're going fishing, and if that don't fetch him nothing will." I had only recently been moved up into Mr. H-'s class, so I was not aware that he was as keen an angler as. he was jolly and kind-hearted-though cane he could, and did. When morning lessons were half through, each master liberated his class for a quarter of an hour. At the end of the fifteen minutes a bell rang, and we of $H \longrightarrow$ 's class knew if we did not clear out of the playground at once we should have to "run the gauntlet!" Mr. H-, in his college cap and gown, stood at the side of the open door. We had to rush past one at a time, and endeavour by fleetness or strategy to avoid the flying cane. Never was the wisdom of "festina lente" more 
impressed on one; for the greater your speed in endeavouring to escape the cane, the faster the master must make his cut to avoid missing the victim. It was better to hasten slowly in close single file - better for all but the last man!

One of my first essays in fly-fishing was for dace in the Thames from the meadows opposite Kew Gardens. These meadows are intersected by deep dykes. There was a school of girls walking along the towing-path on the opposite side of the river. As I was moving along the bank, I suppose I must have been looking at the girls, or I should not have suddenly gone bodily into a dyke six feet deep. Luckily, the tide was low, and the mud was soft; but I did not venture to reappear until the ripples of laughter from across the water had grown faint in the distance. But I caught some fine dace, I remember; for on my way home, when I got to Waterloo Bridge, which then had a toll-gate on it, I had not even a half-penny to pay the gate- 
keeper. But St. Peter is the friend of fishermen, and the offer of some silvery dace in lieu of toll-money was accepted with alacrity.

I have mentioned these small matters because I think if one undertakes to give some account of a favourite author, it will not, at any rate, lessen any interest in what you write, if you can show that your acquaintance with the subject is a familiar one; and I think I may claim to know something practically about angling, from fly-fishing for salmon down to sniggling for eels. Every holiday I have had has been spent in some part of these beautiful Islands, - often after the big wary trout and grayling of Hampshire and other south-country streams, many times to the sweet south country which divides the Bristol from the English Channel, among the vales and dales of Derbyshire and Yorkshire, in the delightful Border country, among Scotch and Irish lake districts and Highland salmon 
rivers, through the Snowdon land, after big pike in the Midlands; in fact, everywhere and anywhere that offered a chance of good fishing. Nor have fish always been the only object of my angling expeditions: often enough it has been to explore some delightful valley referred to in some old writer, or to fish for rare old books on angling in the old bookshops. Beware of taking to collect books on angling. You will find yourself become so attached to the fascinating hobby, that you would, if necessary, pawn the shirt off your back to obtain some coveted edition. Not that one might not select a thousand worse ways of investing time and money than in forming an angling library; for these little shabby volumes of the sixteenth and seventeenth and of earlier and later centuries are growing in value at a marvellous pace.

There is a steady and increasing demand in the United States of America for old books on angling, and indeed on sport generally; and it is pleasant to 
know that the love of out-door sport of all kinds is so strong among the sons and daughters of the great Republican branch of the Anglo-Saxon race. It is this constant drain to America which makes these books become scarcer every year. When I first began collecting, one could secure a good copy of the first edition of Walton for $£ 20$ or $£ 30$. Now it is worth five or six times as much. The fact is, these books never come back into the English market. An Englishman makes a collection; but sooner or later he dies, and the chances are that his collection is dispersed among other English collectors by being sold at auction; and I am convinced it is not so much the competition of English collectors, as the gradual exhaustion of the stock in this country by the Americans, which makes old books on angling fetch a higher price than any other class of book.

Only the other day I purchased a fine copy of Walton's second edition (even 
rarer than the first): its late owner would not part with it until he had my assurance that it was for my own collection, and not to go to America. "I do not see," he said, "why all our rarest books should go to America."

It may be well to warn collectors that . there exist some uncommonly clever spurious editions of Walton, made by aid of photography in Germany. When I say clever, they would not deceive any one who had any acquaintance with a genuine first edition; but few of the many hundreds of collectors have any chance of seeing that, and I know from experience that there are unscrupulous secondhand booksellers. On one occasion, when passing an old book-shop, I looked in, as usual, to see if any fishing-books were for sale. After being shown some common modern editions, the bookseller remembered he had an old Walton upstairs-a first edition. He could not find it, but promised to send it on. The price was ridiculously low, if it proved 
in good condition; and I congratulated myself on having secured a "find." But the book never came; and on calling for it, I was informed there was doubt about its genuineness. There was none until I gave my address.

The art of photography has rendered the manufacture of spurious "early editions" a game worth the candle, so that a word of warning in this respect will not be out of place. I was asked $£ 25$ for one worth about 5s. only the other day.

For this little work generally I will only claim that it deals at greater length with the principal works referred to than is the case in any other single volume. It would have been easy to give many more references in praise of Walton and his writings, but "enough is as good as a feast." That it is published in the three hundredth year since Walton's birth is an accident: it was begun before that "tercentenary" was thought of by me. Indeed, although I have printed on 
the front of "The Fishing Gazette" the date of Walton's birth and death every week for getting on for twenty years now, it was not until Dr. Henshall, who has charge of the angling exhibit at the Chicago World's Fair, wrote to me a month or two ago to say that they intended to celebrate Walton's birthday (as described in his letter to me, quoted on p. 104), that my attention was drawn to the interest connected with August 9 th, I893.

$$
\text { R. B. } M \text {. }
$$

Richimond, Surrey,

April 1894.

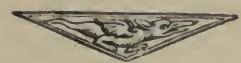





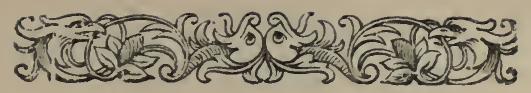

CONTENTS.

CHAPTER I.

PAGE

Piers of Fulham, I 420 -Adventure of Sir Wil-

liam Wallace-St. Patrick and some Fish

and Snake Stories . . . . . I

CHAPTER - II.

The Celebrated Treatyse of Fysshynge wyth an Angle Attributed to Dame Juliana Berners, r496-Bibliographical Account of It-Its Practical Value from an Angler's Point of View-Considered as an Angling Idy! ? ro

\section{CHAPTER III.}

Leonard Mascall's Booke of Fishing with Hooke and Line, 1590-Mascall the Pioneer of Fish Culture in England-Some Extracts from His Work-Directions for Taking Herons, Otters, Sea-Pies, etc.-How to Preserve Fish Spawn-The Parson of Culles -Crayfish Culture-A Crayfish IVarCurious Statement about the Kingfisher"A Pretie Way to Take a Pye" . . 33

\section{CHAPTER IV.}

Michael Angelo an Angler-La Canna de Piscare-Blakey and the Bibliotheca Piscatoria-Mynheer Vandunk . 


\section{CHAPTER V.}

John Dennys' Delightful Secrets of Angling, 1613

- Some Account of the Book and its Author -A Parenthetical Reference to Multiplying Reels and Sir Humphry Davy's SalmoniaThe Secrets compared with Dame Berners' Treatyse-Quotations from the SecretsAngling in the Age of Wood, of Gold, of Silver and Brass-Angling in the Iron Age

\section{CHAPTER VI.}

Gervase Markham's Art of Angling (16r4) and other Books-His Work not merely a Prose Version of The Secrets of Angling-William Lawson, a North-Country Angler and Writer-Barker's Delight-Thomas Barker, a First-rate Trout-Fisher-Walton's Indebtedness to Him-The First Writer to Describe the Use of the Reel or Winch and the Gaff in Salmon-Fishing-His Directions for Fly-Making and Fly-Fïshing . .

\section{CHAPTER VII.}

Walton and the World's Fair, 1893-A Glance at the Times in which $\mathrm{He}$ Lived-Some Account of the Chief Particulars of Walton's Life which have Come Down to Us-No Proof Exists that He was ever a "Sempster, Haberdasher, or Hamburgh Merchant "His Connection with the Ironmongers' Company-His First Marriage-Offices Held by Him in the Parish of St. Dunstan'sin-the-West-Loss of His First Wife and Seven Children during His Residence in Chancery Lane-His Second MarriageHis Connections by Marriage with the Cranmer and Ken Families-Birth of His Son Isaac-Was Probably Residing in 
Clerkenwell when His Compleat Angler was First Published-Walton a Staunch Royalist-Incident After the Battle of Worcester -Death of His Second Wife-Lives at the Houses of Dr. Morley, Bishop of Winchester, and Dr. Ward, Bishop of Salisbury Dies at Winchester, December I5th, 1683 - 103

\section{CHAPTER VIII.}

The First Editions of The Compleat Angler - Effect on My Library of the Abnormally Early May-Fly Season of this Year (1893)Curious Printer's Error in the Copies First Printed of the Angler-Walton's First Title-Page-His "Epistles Dedicatory" and "Addresses to the Reader"-Some Past and Present Money-Values of a First Edition

\section{CHAPTER IX.}

The Second Edition of The Compleat AnglerThe Illustrations - An Interesting Discovery - The Third and Fourth Editions-The more Important Fifth, with Cotton's Addition-Venables' Expcrienc'd Angler, Published with the Fifth Edition-Walton's Letter to Venables, and some Account of the Latter-Charles Cotton's "Instructions How to Angle for a 'Trout or Grayling in a Clear Stream "-Some Account of Cotton -His Friendship with Walton-His Family Affairs and Death

\section{CHAPTER X.}

An Estimate of the Influence of Walton's Book on Angling and Angling Literature-It can Never be Antiquated-Has Kept the True 
Sporting Instinct Alive-Diversity of Baits Recommended by Walton-His Chapter on Trout-Fishing-The Celebrated Fordidge Trout-Walton and His Editors-What would $\mathrm{He}$ think of Some of our Modern Automatic Angling Appliances?-His Religion - His Reference to Hampshire Streams-Notes on other Chapters of His Book-A Tip for Dry-Fly Anglers-Did Walton Keep a Horse?-His Directions for Bream, Barbel, and other Fishing - FishingTackle Makers Mentioned by Walton-His Chapter on Fish-Ponds-A Drink like Nectar $\cdot \cdot \cdot \cdot \cdot\left(\begin{array}{l}163 \\ 16\end{array}\right.$

\section{CHAPTER XI.}

Some Notes on Charles Cotton's Practical Directions in Trout and Grayling-Fishing-Fish Fine and Far Off-Cotton the First Exponent of Clear-Water Fishing for Trout and Grayling-Yorkshire Fly-Rods-Pike Pool-Creeper-Fishing First Described by Cotton, also "Swimming the Worm" for Grayling

\section{CHAPTER XII.}

Some Editions of The Compleat Angler Subsequent to the Fifth-An Interval of over Seventy Years-Moses Browne's Reprints, 1750, 1759, and 1772-John Hawkins's Editions, 1760 to 1784 -The Bagster Edition, I808 - Gosden's Edition, I822 - John Major's Editions-One "Higgs" has a Copy Bound in Wood which he Cut from Cotton's Fishing-House-Some Notes on Major's Editions-How Major Courted Immortality-Pickering's $32 \mathrm{mo}$, His Fine Edition of 1836 , the Result of Seven Years' Labour-Sir Harris Nicolas Walton's Best 


\section{Contents.}

Editor-Some Account of Dr. Bethune's Edition- "Ephemera's" Editions-A German Edition of Walton-Some other Editions, and a Welcome for a New One by Bagster

\section{CHAPTER XIII.}

Lines to Walton Published in $1619-$ Letters and References to Him by the Bishops of Chichester, Winchester, Lincoln, and the Archbishop of Canterbury-Sir Henry Wotton's Letter to Walton-The Commendatory Verses Prefixed to The Compleat Angler-Drayton and Ben Jonson-Dr. Johnson and Walton-An Extract from The American Review, 1830-Wordsworth's Verse-Sir Walter Scott's Reference to Walton and Franck's Northern MemoirsSome Extracts from James Russell Lowell's "Introduction" to an Edition of the Angler -Conclusion

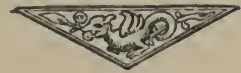




\section{WALTON'S "COMPLEAT ANGLER.”}

\section{A SONNET BY T. WESTWOOD.}

WHAT, not a word for thee, $O$ little tome, Brown-jerkined, friendly-faced - of all my books The one that wears the quaintest, kindliest looksSeems most completely, cosily at home, Amongst its fellows. Ah! if thou couldst tell Thy story-how, in sixteen fifty-three,* Good Master Marriot, standing at his door, Saw Anglers hurrying-fifty-nay, threescore, To buy thee, ere noon pealed from Dunstan's bell :-

And how he stared and... shook his sides with glee.

One story, this, which fact or fiction weaves. Meanwhile, adorn my shelf, beloved of allOld book! with lavender between thy leaves, And twenty ballads round thee on the wall.

* ${ }^{653}$, the date of the publication of "The Compleat Angler" in St. Dunstan's Churchyard. 


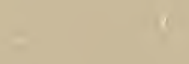




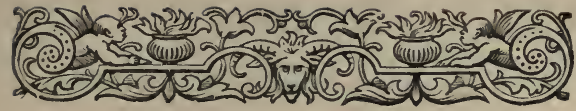

WALTON AND SOME EARLIER WRITERS ON FISH AND FISHING.

\section{CHAPTER I.}

Piers of Fulham, 1420-Adventure of Sir William Wallace-St. Patrick and some Fish and Snake Stories.

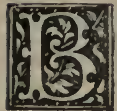

LAKEY, in his Angling Literature-a most interesting and useful little work-quotes from a curious tract, taken from the original manuscript in Trinity College Cambridge, entitled Piers Fulham, supposed to have been written about the year I 420 , and containing probably the earliest known reference to angling in English, but a very short one. The writer says he would never store stews with "pykes" or "breame" or "tenche," because, "be it closed never so well aboute," thieves are sure to steal them. 
"But in rennyng ryvers that bee commone, There will I fisshe and taake my fortune With nettys, and with angle hookys, And laye weris and sprenteris in narrow brookys,

Ffor loochis, and lampreyes, and good layk, I will stele off no mans a strayke."

Angling has long been known as "the contemplative man's recreation." I always thought this expression originated with Walton, as it is the second title of his Compleat Angler; but it appears, from a few lines of preface to the tract of Piers of Fulham on fishing, this is not so :-

"Loo, worshipfull sirs, here after ffolleweth a gentlymanly tretyse full convenyent for contemplatiff louers to rede and understond, made by a noble Clerke Piers of ffulhā, sum tyme ussher of Venus Schole, which hath brieflye compyled many praty conceytis in loue under covert terms of ffysshyng and ffowlyng."

Adventure of Sir William Wallace While Fisifing in Irvine Water.

Another early reference to angling, or at any rate taking fish for sport, is found in The Adventures of Sir William Wallace, written about 1460 by a wandering Scotch bard called Blind Harry. The incident 
Sir William Wallace a Fisherman. 3

took place about a century and a half before Blind Harry's time, so that his account may be looked upon as made up from the traditions current among the Scotch people about their national hero. From an angler's point of view, it is pleasant to think of the great warrior Wallace turning to fishing for recreation, as did Washington and our hero Nelson.

Wallace, near the commencement of his career, is living in hiding with his uncle, Sir Ranald Wallace, of Riccarton, near Kilmarnock. To amuse himself, he goes to fish in the river Irvine, when this fishing adventure takes place.

"So on a time he desired to play

In Aperil the three-and-twenty day,

Till Irvine Water fish to tak he went;

Sic fantasy fell into his intent."

Wallace had good sport. "Happy he was, took fish abundantly"; but presently, some of the retinue of Lord Percy, who was then captain of Ayr, seeing Wallace's success, demanded his fish of him. Wallace meekly replied,-

"It were reason, methink, ye should have part;

Waith should be dealt, in all place, with free heart."

But they are not satisfied with part of the waith (spoil taken in sport), but take all, 
and derisively offer Wallace permission to catch more. The upshot of the affair is that five of his opponents attack Wallace, who kills three of them; the other two escape, and complain to Lord Percy, who inquires how many were their adversaries.

"The Lord speirit, "How mony might they be?"

'We saw but ane, that has discomfist us all.'

Then leugh he loud, and said, 'Foul mot you fall! Sin' ane you all has put to confusion."

And scornfully declines to have IVallace pursued.

St. Patrick and Fish and Snake STORIES.

Ireland has not contributed very largely to the literature of angling, although from a song quoted by Blakey, written nearly a hundred years ago by an angler of Trinity College, Dublin, it would seem that St. Patrick was an angler. He sings :-

"No doubt, St. Patrick was an angler Of credit and renown, sir, And many shining trout he caught Ere he built Dublin town, sir. And story says (it tells no lies)

He fish'd with bait and line, sir ; At every throw he had a bite Which tugg'd and shook the twine, sir.

In troubl'd streams he lov'd to fish;

Then salmon could not see, sir; 
St. Patrick and the Fishermen. 5

The trout and eels, and also pike,

Were under his decree, sir.

And this perhaps may solve a point

With other learned matters, sir,

Why Irishmen still love to fish

Ever in 'troubl'd waters,' sir."

In a copy I picked up at an old bookshop of Swift's translation of Jocelin's Life and Acts of Saint Patrick, the Archbishop, Primate, and Apostle of Ireland, printed-and most beautifully printed-in Dublin in 1809, is a copper-plate copy of the three portraits drawn by Father Thomas Messingham, and prefixed to his Florilegium (Paris, I624). The portraits are of St. Columba, St. Brigida, and St. Patricius. St. Patrick is in the centre, standing on snakes and dragons. Among the miracles attributed to St. Patrick is that of the "river sentenced to perpetual sterility." It appears that the Saint and his companions having landed at the port of Innbherde, in Leinster, where is a river flowing into the sea, which river then abounded with many fishes, the servants of the Saint asked the fishermen, who were drawing their nets full of fish to land, to bestow on them some of their fishes. "But they, barbarous, brutal, and inhuman, answered the entreaty, not only with refusal, but with insult. Whereat 
6 St. Patrick and the Fishermen.

the Saint, being displeased, pronounced on them this sentence, even his malediction, that the river should no longer produce fishes. . . . From that day, therefore, is the river condemned to unfruitfulness." On another occasion the Saint condemned the river "which is called Seyle," near the place called Tailltion, to perpetual sterility, on account of somebody's sins, and the chronicle adds that the river "even to this day beareth no fishes."

In another chapter, which I quote from only for the beauty of one or two expressions in it, we are told how the Saint persuaded to heaven the two daughters of Leogaire, who were." like roses growing on a rosebed: and the one was of a ruddy complexion, and she was called Ethne; and the other was fair, and she was called Fedella,"-who died, "and their friends and their kindred gathered together and bewailed them for three days, as was the custom of the country; and returned their sacred remains unto the womb of the Mother of all human kind."

Irish fishermen seem to have been very stingy in their dealings with St. Patrick. When he was journeying round Connactia preaching, he came to the river Dubh, and entreated the fishermen that out of a great draught of fishes which they had 
taken they would give him some, but they "wholly refused him even one fish"; so the Saint deprived the Dubh of its perpetual abundance of fishes, and enriched another river therewith, called the Drabhaois; " and this river, as being more fruitful, so is it clearer than all the other rivers in Ireland."

Another fish story connected with St. Patrick relates how one of his assistant preachers, Bishop St. Mel, having fallen under unjust suspicion, proved his innocence by "ploughing up the earth on a certain hill, and took by the ploughshare many and large fishes out of the dry land." St. Patrick accepted the miracle as a proof of his bishop's innocence, but " bade him that he should thenceforth plough on the land and fish in the water."

How St. PATRICK RID IRELAND OF SNAKES AND OTHER POISONOUS CReatures.

"Even from the time of its original inhabitants did Hybernia labour under a threefold Plague: a swarm of poisonous creatures, whereof the number could not be counted; a great concourse of Daemons visibly appearing; and a multitude of Evil-doers and Magicians. And these 
S St. Patrick rids Ireland of Snakes

venomous and monstrous creatures, rising out of the earth and out of the sea, so prevailed over the whole Island, that they not only wounded men and animals with their deadly sting, but slayed them with cruel bitings, and not seldom rent and devoured their members. And the Daemons, who by the power of Idolatry dwelled in superstitious hearts, showed themselves unto their worshippers in visible forms; often likewise did they, as if they were offended, injure them with many hurts; unto whom, being appeased with sacrifices, offerings, or evil works, they seemed to extend the grace of health or of safety, while they only ceased from doing harm. And after was beheld such a multitude of these, flying in the air or walking on the earth, that the Island was deemed incapable of containing so many; and therefore was it accounted the habitation of Daemons, and their peculiar possession. Likewise, the crowd of Magicians, Evil-doers, and Soothsayers had therein so greatly increased, as the history of not any other Nation doth instance."

"And the most holy Patrick applied all his diligence unto the extirpation of this threefold Plague; and at length by his salutary doctrine and fervent prayer he relieved Hybernia of the increasing mis- 


\section{And other Poisonous Creatures. 9}

chief. Therefore he, the most excellent Pastor, bore on his shoulder the Staff of Jesus, and aided of the Angelic aid, he by his comminatory elevation gathered together from all parts of the Island all the poisonous creatures into one place :-then compelled he them all unto a very high promontory, which was then called Cruachan-Ailge, but now Cruachan-Phadring; and by the power of his word he drove the whole pestilent swarm from the precipice of the mountain, headlong into the Ocean."

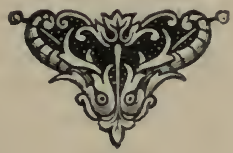




\section{arras}

\section{CHAPTER II.}

The Celebrated Treatyse of Fysshynge wyth an Angle Attributed to Dame Juliana Berners, I496-Bibliographical Account of It-Its Practical Value from an Angler's Point of View-Considered as an Angling Idyl.

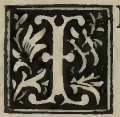

NASMUCH as nothing of the kind preceded it, and all later works are in some measure indebted to it, either for form or matter, The Treatyse of Fysshynge wyth an Angle, attributed to Dame Juliana Berners, must be accounted one of the most interesting, if not the most interesting, of books on angling in the English language.

It was in I486, a few months after the last battle of the Wars of the Roses, when Henry 'Tudor, Earl of Richmond, was proclaimed King of England as Henry VII. on Bosworth field, that "The Schoolmaster of St. Albans" printed The Book of St. Albans, the first sporting work in the English language. It is divided into three parts : the first part treats of Hawking, 
the second of Hunting, and the third of Coat-Armour. Ten years later, in 1496 , Wynkyn de Worde issued a second edition of The Book of St. Albans, adding a fourth part, The Treatyse of Fysshynge.

Sir John Hawkins, in his "Life of Mr. Isaac Walton," prefixed to his fourth edition of The Compleat Angler (I 784), thus refers to The Book of St. Albans:-

"This tract, intitled The Treatyse of Fysshynge zeyth an Angle, makes part of a book, like many others of that early time, without a title; but which, by the colophon, appears to have been printed at Westminster, by Wynkyn de Worde, 1496, in a small folio, containing a treatise on hawking, another on hunting, in verse; the latter taken, as it seems, from a tract on that subject, written by old Sir Tristram, an ancient forester, cited in the forest laws of Manwood, chap. iiii., in sundry places; a book wherein is determined the Lygnage of Cote Armures, the above-mentioned treatise of fishing, and the method of Blasynge of Armes.

"The book printed by Wynkyn de Worde is, in truth, a republication of one known to the curious by the name of The Book of St. Albans, it appearing by the colophon to have been printed there in 1486 , and as it seems with Caxton's letter (vide 
Biographia Britannica, Art. "Caxton," Note L., wherein the author, Mr. Oldys, has given a copious account of the book, and a character of the lady who compiled it). Wynkyn de Worde's impression has the addition of the treatise of fishing, of which only it concerns us to speak.

"The several tracts contained in the above-mentioned two impressions of the same book were compiled by Dame Julyans, or Juliana Berners, Bernes, or Barnes, prioress of the nunnery of Sopwell, near St. Albans; a lady of noble family, and celebrated for her learning and accomplishments, by Leland,* Bale, Pits, Bishop. Tanner, and others; and the reason for her publishing it in the manner it appears in, she gives us in the following words :"And for by cause that this present treatyse sholde not come to the hondys of eche ydle persone whyche wolde desire it yf it were enpryntyd allone by itself, and put in a lytyll plaunflet, therefore I have compylyd it in a greter volume of dyverse bokys concernynge to gentyll and noble men, to the entent that the forsayd ydle persones whyche sholde have but lytyll mesure in the sayd dysporte of fysshyng sholde not by this. meane vtterly dystroye it."

* This is said to be a mistake, as he does not mention the name. 
It is evident that Hawkins obtained this information about Dame Juliana Berners from Oldys.

Mr. IVilliam Blades, in his most interesting "Introduction" to Mr. Elliot Stock's very fine facsimile reprint (r88r) of The Boke of St. Albans, devotes some pages to the work of demolishing the claims which for over a century have been made on behalf of Dame Juliana Berners by biographers and editors of the celebrated Boke. He says there is "not the shadow of evidence" that she wrote The Treatyse of Fysshynge, and " not a particle of evidence that she ever presided over the nunnery of Sopwell"; and yet Mr. Blades appears to think that she existed, for on another page he says, "that the greater portion of the book on Hunting was compiled by Mistress Barnes is probably correct." But whoever gave us the treatise of fishing makes no claim to have written it. $\mathrm{He}$ or she distinctly says, "I have compyled it." Mr. Van Siclen, who edited an American reprint, thinks it may have been written by Dame Juliana, because only a woman could have given such directions for making a rod, and that no man could have beer: guilty of "so delightful a non sequitur in many of the arguments"; which, as 
another editor* says, is "an ungallant hypothesis."

Sentimental reasons apart, it seems to me that Dame Juliana Berners has a better claim to be considered the compiler of the first English work on fishing than any one else ; for no claim is made for any other body; and until such claim is made and substantiated, let us believe that the teacher of Walton was this "Fomina illustris! corporis et animi dotibus abundans ac forma elegantia spectabilis."

For a most careful and minute description of the various reprints of The Book of St. Albans and The Treatyse of Fysshinge, see Westwood and Satchell's invaluable Bibliotheca Piscatoria-a work without which it may most truly be said no angling library is complete. Alas that both compilers are dead, and no one has, so far, continued it!

* "Treatyse of Fysshynge wyth an Angle. Edited by Piscator. Privately printed. Edinburgh, 1885 ." A dainty little edition translated from the old black letter of the original into present-day typography, but containing such errors as "below" for "yellow," "dysporte" for "dystroye," etc. But the most desirable of all the reprints is the facsimile reproduction published by Mr. Elliot Stock, with a most pleasant "Introduction" by an angler and well-known angling writer-the Rev. M. G. Walkins, M.A. 
Illustrations in the "Treatyse." Is

The "Treatyse" from an Angler's Point of View.

It is nearly four hundred years since this charming little Treatyse was first pub lished, and it has often been more or less gently ridiculed by writers who have judged it by the "rudeness" of the illustrations or the "quaintness of its orthography," rather than by the value of its descriptions of rods, tackle, baits, and how and when to use them.

The author's reputation as an instructor in the art of angling would have been much higher than it has generally been rated if the illustrations had been omitted. They have been reproduced over and over again in works on angling, merely for the purpose of showing what a vast difference there is between our modern tackle and that apparently in use at the time of this writer; but it is possible that Wynkyn de Worde, thinking to increase the value of the work he was reprinting, added the illustrations-certainly there is nothing in the text to give one the idea that such coarse hooks, lines, leads, etc., were used.

\section{The Rod.}

The instructions given, if followed out at the present day, would produce a well- 
seasoned rod in three pieces, - the butt hollow, of hazel, willow, or aspen, with a ferrule to receive the second joint, which is to be of hazel, with a "fair shoot of blackthorn, crab-tree, meddler, or juniper" spliced to it for top joint.

The wood for the rod is to be cut between Michaelmas and Candelmas-i.e., in the winter. The wood is to be "set" straight in a hot oven (as you may any day see the Redditch and other rodmakers do it in this year 1893), allowed to cool and dried for a month, then fastened to a large straight piece of wood, and the butt hollowed out, first by passing a red-hot iron through the pith, and after that enlarging the hole by many larger irons, and so tapering it. The butt is then to be allowed to cool, and after two days is unfastened and smoke-dried in the roof until thoroughly dried. The other joints are to be seasoned in the same way, and you thus get a rod which "will be light and full nymbyll to fish with." What is there in such a rod to laugh at?-a light hollow butt, a springy second joint spliced to a fine tough top; for the words "take a fair shoot of blackthorn," etc., show clearly no stiff weaver's beam of a rod is intended, such as that depicted in the printed work. 


\section{The Line.}

For fastening the line to the rod an excellent plan is recommended, and one still in use among anglers who do not use a running line,-and your " crack" Lea roach angler disdains to use such an aid in killing his fish. Instead of fastening the line merely to the extreme point, you are to secure a piece of line to the splice between the top and the second joint, and then carry it down to the point and make a loop to fasten your main line to, the object being to reduce the risk of losing fish and tackle if the fine top should break, as the line would still be fastened to the stouter wood at the splice.

Recipes for colouring horsehair yellow, brown, green, tawny, russet, and dusky colours are given. Walton, more than a century and a half later, reproduces some of them almost word for word and without acknowledgment. What! dear old Izaak among the plagiarists! But more of this when we come down to his time.

Then we are told how to twist horsehairs together to make a line, and the number of hairs to use for various kinds of fish, thus :- 
For minnows . . . . I hair.

For small roach, bleak, gudgeon, and ruffe . For dace and large roach. . . . 3 hairs.

For the perch, flounder, and small bream, or "bremet," as it is here called . . . . 4 hairs.

- For the chub, bream, tench, eel . . . 6 hairs.

For the trout, grayling, barbel, and great chub . . . . . 9 hairs.

For the great trout, with 12 hairs.

For the salmon, with . I6 hairs.

And for the pike . . with a chalk line, armed with a wire at the end.

\section{The Hook.}

Dame Juliana gives detailed instructions in the manufacture of hooks, and the coarse illustrations in the Treatyse are again a libel on the text ; for she recommends for small fish that the hooks should be made of the finest steel needles you can find; those for larger fish of larger needles, such as those used by embroiderers, tailors, and shoemakers. She mentions the spear-pointed shoemaker's needle, perhaps thus anticipating by four centuries the bayonet-pointed hooks and gaffs for 


\section{Leads and Floats.}

which we anglers of the present day have to thank that genial angler and angling writer Dr. John Brunton, M.A.

We are told how to soften these needles, barb them, shape them, and re-temper them, and then how to fasten the line to them, so that the latter is bound on inside the shank next the point, and not outside - a bit of advice which has been repeated by almost every angling writer after her.

\section{Leads and Floats.}

Here again the illustrations-rough woodcuts as they are-do no manner of justice to the text. The leads are to be made round and smooth, so that they do. not catch on stones or weeds, and in size, are to be regulated according to the nature of the fishing, and are to be only "so heavy that the least pluck of the fish" pulls the float down.

The instructions for making floats have never been improved upon; indeed, only the other day one of the best roach anglers living * sent me some floats of his own make which seem to me to be formed exactly on the lines laid down by Dame Juliana. She says :-

"Take a good cork which is clean

* Mr. E. J. Walker, of the Piscatorial Socicty. 
without many holes, and bore it through with a small hot iron, and fit into it a quill strong and straight. The larger the float, the greater must be the hole and the quill. Shape the cork large in the middle and small at both ends, and specially sharp at the lower end. Then make the cork smooth on a grinding stone. And for a line of one hair the size of the cork should not be larger than a pea, for a line of two hairs of a bean, and for a line of twelve hairs a walnut; and so every line after the proportion."

An egg-shaped cork with a porcupine quill through it, made in various sizes, is to this day the best float an angler can use. An idea of the sizes of the leads she recommends is easily and accurately obtained by considering what the floats she describes will carry: one float is to be the size of a pea, another the size of a bean, another the size of a walnut-not the leads, but the floats!

\section{Baits.}

Of these almost all that are best are here recommended; and indeed I think that anglers of the present day might with great advantage take a lesson from this Treatyse and from Walton, and give the the fish a greater variety to select from; 
The First Mention of Fly-Fishing. $2 \mathrm{I}$

instead of worms, paste, gentles, and gentles, paste, worms, why not try this for barbel, for instance?-

"Take some good fresh cheese, lay it on a board, and cut it into small square pieces the size of your hook. Then take a candle and burn it while on your hook till it be yellow, then bind it on your hook with silk."

Toasted cheese is good both for mice and men; then why not for fishes? It has a strong appetising scent, and is a clean, wholesome, pleasant bait to use.

If my little work was intended as a practical treatise on angling, I should quote all the baits for all the various fish given by Dame Juliana, for I am sure in the course of centuries we have forgotten much that might with profit be remembered; but I must only glance at her book, and point out that she is the first to mention fly-fishing," and to give a list of flies for the fishing months of the year. She even notes that, among other baits for the salmon, "you may also take him with a fly in like form and manner as you do a trout or grayling"-adding, "but it is seldom seen."

* I am not unmindful of that artificial hippurus which the Macedonians used, but every writer on fly-fishing has cast that fly. 
Fly-fishing must have been practised much earlier than the period of this Treatyse; for how otherwise would such a complete description of artificial flies for the different months have appeared in it ? Nothing but gradual evolution extending over perhaps centuries could account for this list of the-

"XII. flyes wyth whyche ye shall angle to $\bar{y}$ trought and grayllyng and dubbe lyke as ye shall now here me tell.

Juliana Berners' List of Artificial FuIES.

\section{"Marche.}

"The donne flye, the body of the donne woll and the wyngis of the pertryche. A nother doone flye: the body of blacke woll : the wynges of the blackyst drake : and the Jay under the wynge and under the tayle.

\section{"Apryll.}

"The stone flye, the bodye of blacke wull : and yelowe under the wynge, and under the tayle and the wynges of the drake. In the begynnynge of May a good flye, the body of roddyd wull and lappid abowte wyth blacke sylke: the wynges of the drake and of the redde capons hakyll. 


\section{"May.}

"The yelow flye, the body of yelow wull: the wynges of the redde cocke hakyll and of the drake lyttyd yelow.* The blacke louper, the body of blacke wull and lappyd abowte wyth the herle of $y$ pecok tayle: and the wynges of $y$ redde capon $\mathrm{w}^{\mathrm{t}}$ a blewe heed.

\section{"June.}

"The donne cutte: the body of blacke wull and a yelow lyste after eyther syde : the wynges of the bosarde bounde on with barkyd hempe. The maure flye, the body of dolke wull, the wynges of the blackest mayle of the wylde drake. The tandy flye at saynt Wyllyams daye, the body of tandy wull and the wynges contrary eyther ayenst other of the whitest mayle of $\bar{y}$ wylde drake.

$$
\text { "Juyll. }
$$

"The waspe flye, the body of blacke wull and lappid abowte $\mathrm{w}^{\mathrm{t}}$ yelow threde : the winges of the bosarde. The shell fly at saynt Thomas daye, the body of greene wull and lappyd abowte wyth the herle of the pecoks tayle: wynges of the bosarde.

* Stained yellow (for the "May Fly"). 
"August.

"The drake flye, the body of blacke wull and lappid abowte wyth blacke sylke : wynges of the mayle of the blacke drake wyth a blacke heed."

I have often thought I should like to have a set of Dame Juliana's twelve "flyes," dressed neatly on eyed hooks, to try on the trout and grayling of the Test and Itchin. Is not that "June fly" she calls the "Tandy fly" also meant for the May fly? "The body of tandy wool and the wynges contrary eyther against the other of the whitest mayle of $y^{\mathrm{e}}$ wylde-drake." This light drake hackle, dressed so that the feathers lie "contrary eyther against the other," is our nineteenth-century May fly ; and I like that "whitest mayle," for I have killed more and larger trout with a very light-coloured Egyptian goose wing than with any other feather, and prefer it at times to the softer and darker Canadian duck feather.

"Ye Redde Capon's Hakyll."

It is just four centuries since Dame Juliana recommended a red capon or red cock's hackle, and it is pleasant to find 
that "The History of the Red Hackle" is the title* of the second chapter of a very delightful modern treatise on fly-fishing, entitled Favourite Flies, by Mrs. Mary Orvis Marbury, an American lady; and a very interesting chapter it is, showing " how one little fly has held its name and form from century to century." Most of the writers of any note who have recommended a red cock's hackle for use in the imitation of some natural or unnatural fly are quoted, from Elian's famous description, in his De Animalium natura, of the artificial fly made by the Macedonians from "feathers which grow under a cock's wattles," down to Dame Juliana, Walton, Cotton, and the writers of our own day, including Pennell, Halford, Pritt, etc. The coloured plate of seventeen "hackle flies "which illustrates this chapter is very good indeed. If our authoress had written nothing but this " History of the

* "Favourite Flies and their Histories. By Mrs. Mary Orvis Marbury. With many replies from practical anglers to inquiries concerning how, when, and where to use them. Illustrated by thirty-two coloured plates of flies (nearly three hundred flies), six engravings of natural insects, and eight reproductions of photographs. Boston, U.S.A.: Houghton, Mifflin, \& Co.; London: Sampson Low, Marston, \& Co., Limited, St. Dunstan's House, Fetter Lane." 
26 "Treatyse" as an Angling Idyl.

Red Hackle," she would have proved her title to an honoured place among the great army of angling writers.

But I must reluctantly leave this practical portion of The Treatyse of Fysshynge with just one more reference to the illustrations which have, as previously mentioned, been so often ridiculed. If they are considered as they should be, in connection with the instructions given as to the making of the various things they represent, they will receive anything but ridicule from a practical angler. Take the illustrations of hooks in different sizes; they are rough diagrams certainly, but admirable in shape, being far better adapted for both hooking and holding than some of our modern hooks.

The "Treatyse" as an Angling Idyl.

It is impossible for an angler who loves fishing as much, or perhaps more, for its delightful and inseparable connection with all that is sweetest in country life and natural scenery, than for itself, to read Dame Juliana's eloquent prologue in praise of angling without experiencing a feeling of love and veneration for this fair saint of the angler's calendar. Who shall say how much her simple words in praise of "good 
dysportes and honest gamys" have influenced the generations of English men and women which have passed away since this sweet lady's time? Twenty editions of it have been published, and it has been quoted and copied times out of number.

"Here begynneth the Treatyse of Fysshynge Wyth an ANGLE.

"Salomon in his parablys sayth that a good spyryte makyth a flourynge aege, that is a fayre aege and a longe. And syth it is soo: I aske this questyon. Whiche ben the meanes and the causes that enduce a man into a mery spyryte? Truly to my best dyscrecōn it semeth good dysportes and honest gamys in whom a man joyeth without ony repentannce after. Thenne folowyth it $\bar{y}$ gode dysportes and honest games ben cause of mannys fayr aege and longe life.* And therfore now woll I chose of foure good dysportes and honeste gamys, that is to

* James Russell Lowell, one of the greatest of American authors and critics, in referring to Walton's hope, when eighty-three years of age, that he should next year pay another visit to Cotton and the Dove, adds: "This was in his eightythird year, and implies in him that longevity, the taste for out-of-door sports, and of the muscle to endure their fatigues which are almost peculiar to Englishmen." 
wyte: of huntynge: hawkynge: fysshynge: and foulynge. The beste to my symple dys̄crēcōn why then is fysshinge: callyd Anglynge with a rodde : and a lyne and an hoke. And therof to treate as my symple wytte may suffyce: both for the sayd reason of Salomon and also for the reason that phisyk makyth in this wyse.

"Si tibi deficiant medici medici tibi fiant: hec tria mens leta labor et moderata dieta.

"Ye shall vnderstonde that this is for to saye, Yf a man lacke leche or medicyne he shall make thre thynges his leche and medycyne: and he shall nede never no moo. The fyrste of theym is a mery thought. The second is labour not outraged. The thyrde is dyete mesurable."

After a pleasant discourse of the discomforts and disappointments which often attend the hunter who "blowyth tyll his lyppes blyster, and whan he wenyth it be an hare full oft it is an hegge hogge," and the "fawkener who often leseth his hawkes," our authoress says :-

"Thus me semyth that huntynge and hawkynge and also fowlynge ben so laborous and grevous that none of theym maye perfourme nor bi very meane that enduce a man to a mery spyryte: whyche is cause of his longe lyfe acordynge unto. 
"Treatyse" as an Angling Idyl. 29

y sayd parable of Salomon. Dowteles thene folowyth it that it must nedes be the dysporte of fysshynge wyth an angle. For all other manere of fysshynge is also laborous and grevous: often makynge folkes ful wete and colde, whych many tymes hath be seen cause of grete Infirmytees. But the angler may have no colde nor no dysease nor angre, but yf he be causer hymself. For he maye not lese at the moost but a lyne or an hoke; of whiche he maye have store plentee of his owne makynge, as this symple treatyse shall teche hym. Soo thenne his losse is not grevous, and other greyffes maye he not have, savynge but yf ony fisshe breke away after that he is take on the hoke; or elles that he catche nought: whyche ben not grevous. For yf he faylle of one he maye not faylle of a nother, yf he doóth as this treatyse teechyth; but yf there be nought in the water. And yette atte the leest he hath his holsom walk and mery at his ease, a swete ayre of the swete savoure of the meede floures : that makyth hym hungry. $\mathrm{He}$ hereth the melodyous armony of fowles. He seeth the yonge swannes: heerons: duckes : cotes and many other foules wyth their brodes, whyche me semyth better than alle the noyse of honndys : the blastes of 
30 "Treatyse" as an Angling Idyl.

hornys and the scrye of foulis that hunters: fawkeners and fowlers can make.

"And yf the angler take fysshe: surely thenne is there noo man merier than he is in his spyryte.

"Also who soo woll vse the game of anglynge : he must ryse erly, whiche thyng is prouffytable to man in this wyse: That is to wyte : moost to the heele of his soule. For it shall cause hym to be holy, and to the heele of his body. For it shall cause hym to be hole. Also to the encrease of his goodys. For it shall make hym ryche. As the olde englysshe prouerbe sayth in this wyse :-

" "Who so woll ryse erly shall be holy, helthy, and zely.'

"Thus have I provyd in myn entent that the dysporte and game of anglynge is the very meane and cause that enducith a man in to a mery spyryte, whyche after the sayde parable of Salomon and the sayd doctryne of phisyk makyth a flourying aege and a longe.

"And therefore to al you that ben vertuous, gentyll, and free borne I wryte and make this symple treatyse followynge: by whyche ye may have the full crafte of anglynge to dysport you at your luste : to the entent that your aege maye the more floure and the more lenger to endure." 
Dame Juliana's Exordium. 3 I

The practical instructions forming the bulk of the little work are then given, and it closes with

\section{Dame Juliana's Exordium.}

"Here followyth the order made to all those whiche shall have the vnderstondynge of this forsayde treatyse and vse it for theyr pleasures.

"Ye that can angle and take fysshe to your plesures as this forsayd treatyse techyth and shewyth you:

"I charge and requyre you in the name of alle noble men that ye fysshe not in no poore mannys severall water: as his ponde : stewe : or other necessary thynges to kepe fysshe in wythout his lycence and good wyll.

"And also yf ye doo in lyke manere as this treatise shewyth you, ye shal have no nede to take of other mennys; whiles ye shal have ynough of your owne takynge yf ye lyste to labour therefore. Whych shall be to you a very plesure to see the fayr bryght shynynge scalyd fysshes dysceyved by your crafty meanes and drawen vpon londe.

"Also that ye breke noo mannys heggys in goynge abowte your dysportes, 
ne opyn noo mannes gates but that ye shvtte theym agayn.

"Also ye shall not vse this forsayd crafty dysporte for no covetysenes to thencreasynge and sparynge of your money oonly, but pryncyppally for your solace and to cause the helthe of your body, and specially of your soule.

*

"Also ye shall not be to ravenous in takyng of your sayd game as to moche at one tyme, which ye maye lyghtly doo yf ye doo in every poynt as this present treatyse shewyth you on every poynt. Wyche sholde lyghtly be occasyon to dystroye your owne dysportes and other mennys also. . . .

"Also ye shall besye yourselfe to nouryssh the game in all that ye maye: and to dystroye all suche thynges as ben devourers of it. And all those that done after this rule shall have the blessynge of God and saynt Peter, whyche he theym graunte that wyth his precyous blood vs boughte."

And so endeth this "lytyll plaunflet," so full of the true spirit of sport. Would that it could be said of all our modern "gamys and dysportes" that they were pursued under the golden rules laid down by its writer. 


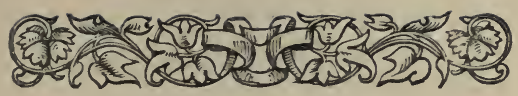

\section{CHAPTER III.}

Leonard Mascall's Booke of Fishing with Hooke and Line, I590-Mascall the Pioneer of Fish Culture in England-Some Extracts from His Work-Directions for Taking Herons, Otters, Sea-Pies, etc.-How to Preserve Fish Spawn -The Parson of Culles-Crayfish CultureA Crayfish War-Curious Statement about the Kingfisher- "A Pretie Way to Take a Pye."

"Samias. Worse and worse, but how wilt thou live?

"Epiton. By angling; O 'tis a stately occupation to stand foure houres in a colde morning, and to have his nose bitten with frost before his baite be mumbled with a fish."-From Endimion, by J. Lilly, I59I.

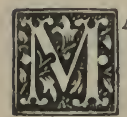

ANY works on sport of a general character have been published in English, and, when angling has been included, we generally find that the author or compiler of the work has been content to take one of the existing books on the subject of angling, and make up his section on fishing from that, 


\section{Leonard Mascall's "Booke."}

usually without acknowledgment, and often, as the Bibliotheca Piscatoria says, " marring the matter taken by the clumsiness of the transfer."

This is said to have been the case with the first work published after the famous Treatyse-viz., Leonard Mascall's Booke of Fishing with Hooke and Line, and all other instruments thereunto belonging. Another of sundrie Engines and Trappes to take Polcats, Buzards, Rattes, Mice and all other kindes of vermine and beasts whatsoever, most profitable for all Warriners, and such as delight in this kinde of Sport and Pastime. Made by L[eonard] M[ascall]. [Woodcut of fisher and fowler.] London. Printed by John Wolfe, and are to be solde by Edwarde White drelling at the little North doore of Paules at the Signe of the Gunne. I590. B.L. pp. 93, and folding plate 4to. According to the Bibliotheca Piscatoria, other editions appeared in I596, I600, and r6or. There is a copy of the first edition in the British Museum.

The Pioneer of Fish Culture in ENGLAND.

Leonard Mascall deserves special praise for the extremely valuable instructions in practical fish culture which he gives, the 
The Pioneer of Fish Culture. 35

first of the kind published in English; in fact, he must be looked upon as the pioneer of fish culture and fish preservation in this country.

Westwood and Satchell's Bibliotheca Piscatoria was published in 1883 , and its reference to Leonard Mascall's book is almost confined to the statement that he took it from Dame Juliana, and spoiled what he took; but this inadequate and somewhat unfair notice is amply atoned for by the excellent reprint of the work which Mr. Thomas Satchell published next year (r884) with a preface and glossary. This reprint is now out of print, and it was only by a fortunate accident that I discovered its existence, when looking over the catalogue of a private collection of angling books belonging to my friend Mr. W. B. Adlington, who very kindly lent his copy to me.

Having for many years advocated the introduction into this country of some of the Continental methods of fish culturemore especially with reference to what the Germans call summer spawning fish, to distinguish them from the salmon and trout which spawn in the winter months-I was delighted to find that Mascall had done the same thing four centuries ago. There is pretty clear 


\section{Mascall and Dame Juliana.}

evidence that his book was very little known, in the fact that the very simple methods of fish culture which he describes and illustrates are, as far as I am aware, not referred to by subsequent angling writers. Even North, in his very valuable Discourse of Fis/ and Fish-Ponds, I7I3, would have much improved his work had he included in it some of the methods described by Mascall.

As Mr. Satchell clearly shows, Mascall took his directions for fishing with "hooke and line" bodily from Dame Juliana Berners; about half his Booke is made up in this way, but the remainder is most of it, I think, written from his own practical experience, with the exception of a few passages which he acknowledges as "thus much taken of Stephanus in French."

Mr. Satchell says : "How much of the rest of the book is the author's own (i.e., beyond that taken from Dame Juliana), and how much is drawn from other sources, I have not been able precisely to ascertain, but chapters fifty-nine to seventy are, I find, taken from L'Agriculture et Maison rustique de M. Charles Estienne, Docteur en Médicine (liv. iv., chap. I3-18, 22-26), and the particular edition used appears to have been that ' $A$ Paris, 
chez Jacques Du-Poys, r570.' This is inferred from the headings of the chapters - not continued in later editions - which Mascall has preserved, and one of which has been curiously mistranslated. This is chapter sixty-six, p. 36 , headed, 'To make it drie.' The words in Estienne's are 'Pour les seiches' - to take 'crayfish.'"

Not the least interesting of the hints given by Mascall is that for taking eels with "a proching hooke" - a method in use to this day, and one with which as a school-boy I have taken many a fine eel in the daytime and in clear water.

Here is Mascall's description:-

"There is another kind of hooke, calde a proching hooke, which is made without a barke [barbe]; this kind or manner of hookes are to put in a hole in the banke, or betwixt two bordes at a bridge or water, or betwixt two stones where they lie open, for there commonly lieth the great Yeles, and if there bée any yéeles, they will take it anon: which proch, is wier whipt on a pack thréedes end, and covered with a great worme, and therewith prochin to the saide holes. . . .

"As soon as ye féele she hath the baite, plucke away your rodde, for it doth nothing but guide your proch into $\mathrm{y}^{\mathbf{e}}$ 
holes, and then draw softly your packthréed line, and hold a while, and he will yéelde-if you do plucke hastely he will holde so stiffe, ye shall breake your line, or teare his mouth : there holde hard still and at length he will yéelde, and come forth. And where ye shall sée any hole in the bottome of a brooke or river, there is like to lie an yéele, put there in your proch, and he will soon byte if he be there. Thus much for the order of the proch hooke to take the Yéele."

Mascall gives practical instructions not only how to take fish, but also "how to save and preserve" them "against such devourers and raveners as hath and will destroy them, as the Herne, Dobchicke, the Coote, the Cormorant, the Sea-pie, the Kingfisher and such like, and also the Otter."

\section{To Catch the "Herne."}

'To take the heron, he recommends baiting a hook with a minnow or other small fish, and then fastening it to a "greene" line or line the colour of the water she haunts, and pegging it down, so that she may have to wade half a foot deep unto it, or else the kite or crow will soon have it. 
To TAKe the OtTer, OR "IVATER WOLFE."

Very interesting, and evidently from practical knowledge, are Mascall's directions for making otter-traps, or "weles," as he calls them. From the excellent illustrations he gives there would not be much difficulty in constructing one of them; indeed, I hope to get Mr. Bambridge, of Windsor, whose capital osier eel-traps I have found most useful on the Itchen, in Hampshire, to make one for me, for the keeper tells me otters have been very busy among the trout and grayling. At the present time, as far as I am aware, only steel traps are used for taking otters, and I have often heard keepers complain that it is difficult to get a trap that will hold an otter. Again, these steel traps, like large rat-traps, are dangerous things to use, as ducks, geese, and other domestic birds and animals may be killed by them, or bathers seriously injured.

But if Mascall's otter "wele " is effective, it would be dangerous only to otters. I wonder if any descendants of those who made them in Mascall's time are living? He says : "These Otter Weles are made at Twyford, by sides Reading. There be two of the Gootheriches which lives much 
by making of such, and other Weles. Also the Otter Wele is made at Dorney, by Windsor, by one called Twiner." He adds that "it should be made of good round Ozyars of the Hasell rodde or gore rodde, for those are the best."

In a few words Mascall's "wele" may be described thus :-It is a double basket trap made of strong hazel stick. At the entrance to the inner compartment, containing the bait is a spring. The otter creeps into the outer compartment and on endeavouring to get at the fish releases the spring and causes a "gredyern" [gridiron] door to fall, and so entraps him. "As soon as he hears it fall, he will turne back without touching any fish, gnawing at the gredyern where he came in, and so is drowned."

He warns the reader against using an old "wele," as, if it is rotten and the otter escapes, "ye shall hardly take him of a long time after, for he is very subtill to be caught againe in such a wele."

\section{Fish Culture in Mascall's Time.}

In view of the great strides made in fish culture during the past thirty years, it is interesting to find that some of the methods so much advocated of late were 
known centuries ago. I should like to see the following instructions printed and exhibited on the walls of all angling clubs.

To Preserve Spawn in Spawning TIME.

"A chiefe way to save spawne of fish, in March, Aprill, and May, is thus :-Ye shall make fagots of wheate, or rie strawe, all whole strawe not bruised, or of reede. Bind these faggots together with three bondes, and all about thereon sticke of young branches of willowe. Then cast them in the water among weedes, or by the bankes, and put in each faggot two good long stakes, driven fast to the ground, and let your fagots lie covered in the water halfe a yeard or more. So the fish will come and shed their spawne thereon, and then it will quicken therein, so that no other fish can come to destroy or eate it, and as they waxe quicke they will come forth and save themselues.

"Thus much for the preserving of spawne in the spring and spawning time : this is a good practise to preserve the spawne of all scaled fish.

"These faggots ye may make and lay in all rivers, poundes, or standing waters. Your fagots had neede to be a yeard and 


\section{To Take Sea-Pies, Crows, etc.}

a halfe long, and bound with three bandes not hard, two bandes a foote from the endes, and another band in the middest, and lay them as I have afore declared.

"Also some doe use to hedge in corners in rivers and pondes with willow, and thereon fish doe cast their spawne and so breedes."

An Ingenious "MANner of Way to Take Sea-Pies, Crows, and other Pyes."

Mascall gives an illustrated description of this. He says if you take two small "oziars" and bend them together crosswise near the end, and tie a bait to the twigs with a short thread, then lime the twigs and place them on some water weed or rush, or suchlike in the midst of the river, the birds will "flie away with it in their bylles, and soon they shall be lymed therewith ... for the twigs will turne and touch her wings, and then the pye will fall." He adds that "you may take seapies, crowes, and other Pyes therewith, but that you will hardly catch the Kyte, because he takes the bayte in his feete, and the other takes it in their billes."

"Thus much for the taking of the Sea-pie." 
Mascall's Opinion of the Flavour OF "FroGges."

"In many places frogges, being well drest, they eate like fish, and is calde a kinde of fish, and doe taste as well as a young poullet, for I tasted my part of many."

He Advocates the Cultivation of a Fish NOW Very RaRe in England -THE "POUlt" (Eel-Pout or Burbot *).

"There is a kind of fish in Holand, in the fennes beside Peterborrow, which they call a poult; they be like in making and greatness to the whiting, but of the cullour of the Loch [loach]; they come forth of the fenne brookes, into the rivers nigh there about, as in Wandsworth river $\dagger$ there are many of them. They stirre not all the sommer, but in winter when it is most coldest weather. They are taken at Milles in IVelles [eel-baskets], and

* The statement in the Bibliotheca Piscatoria that Franck (1694) is the first English writer on angling who describes that mystical fish the "burbolt" is incorrect, as my quotation from Mascall (1596) proves.

† The Wandle- not many years ago the purest chalk stream in England, now tainted by the water from Croydon's sewage farm, and polluted by village drainage. 


\section{To "Breede Millers-Thumbes," etc.}

at waters [weirs] likewise. They are a pleasant meats, and some do thinke they would be as well in other rivers and running waters, as Huntingdon, Ware, and such like, if those waters were replenished with them, as they may be with small charge.

"They have such a plentie in the fenne brookes, they feede their hogges with them. If other rivers were stored with them, it would be good for the common wealth, as the Carpe which came of late yeares into England. Thus much for the fenne pult."

This fish is now only seen occasionally in the Trent and a few other rivers.

There is not much order in Mascall's book; in fact, it is a collection of notes thrown together in rather a haphazard manner, and, as previously mentioned, it it is not quite clear how much "is taken of Stephanus in French." But there is an English flavour about the names of places mentioned in his account of how

"To Breede Millers-Thumbes AND.

Loches in Shallow BroOkes or RIVERS.

"The fish called Loches, and the other called Millers-thumbes or Culles, * they

* In Ireland the loach is called "colley." 
always feede in the bottome of brookes, and rivers. They are fish holesome to be eaten of feeble persons having an ague, or other sicknesse." He then recommends that, in order to preserve these useful little fish from "water rats and all other fowles" rows of small heaps of stones should be placed in shallow gravelly streams. "Like as there is a shallow river running from Barcamstede to Chestum, and so to Chane: also by Croydon, and other places, wherein they might breede of the said fish great store, if they were so given. The like river runnes in Hampeshire bysides Altum, increasing by diverse springes, and runnes shallow in many places, and by a certaine parish there called ; the Parson thereof hath tolde me, he hath had so many of the saide Culles and Loches, to his tithe weekly, that they have found him sufficient to eate Fridays and Saturdays, whereof he was called the

\section{"Parson of Culles."}

In the reprint from which I am quoting the name of the parish of the Parson of Culles is left blank: I know not if it is so in the original.

Mascall is probably following his French teacher when he tells us quaintly of the 
times and seasons when fish are "holesome" : for instance, that "Cockles and such are not kindly but in the monethes of March, Aprill, and May."

After relating how strictly the laws are enforced in France against the taking of under-sized fish, fish out of season, or destroying fish by unlawful means, he adds :-

"I WOULD TO GOD IT WERE SO HERE WITH US IN ENGLAND, and to have more preservers and lesse spoylers of fish out of season and in season: then we should have more plentie than we have through this Realme."

It is pleasant to know that, if Mascall could revisit "this Realme" and then journey through France, he would find that his comparison of the state of affairs as regards the inland fisheries would have to be reversed; indeed, our rivers never were in such a sad state as are those of France now-netted, poached, poisoned, dynamited, fished to death, her grand salmon rivers and lovely trout streams now, alas! toc often utterly ruined. The chief destroyers of our inland fisheries are the manufacturer, the town councillor, and last, but by no means least, the sanitary authority. 


\section{Crayfish Culture.}

Another interesting bit of fish culture is given under the heading "The breeding of Crevis." Our author says :-

"The fresh water Crevis, commonly lives and lyes in bankes and holes in rivers and brookes, and they are a holesome fish for all sick and weake persons. They will cast their spawne in the Spring about the moneth of May, and will shed it on stones, and weedes in the bottome, whereof most is eaten up with yeeles and water rats, as some suppose.

"Therefore it were not vnmeete to make fagots of hole straw to save the spawne as aforesaide. Also they will soone be driven with floods downe the streame, in few yeares they will greatly increase, if they be not taken with mens handes, and kild with Rats, for they will lie in holes and under stones, and weedes, and so are soone taken : for they cannot flie fast away. If they be taken in May it will be a great spoyle in their increase, for commonly they then doe shed their spawne. The Water-rat is also a great devourer of them lying in holes: and where many rats are, they cannot lightly prosper or increase there.

"'Thus much for the fresh water 'Crevis.' Ye may store any brooke or river with 
them, but especially he loves the sandie and gravely running waters."

Mascall gives an excellent illustration of the crayfish-not quite equal to that in Professor Huxley's delightful monograph on the subject, of course, but excellent, considering the centuries between them. The gastronomical value of the crayfish is no slight one, as all will admit who have tasted it on the Continent in Potage Bisque, or as a garnish with fish, or simply boiled and eaten with salad and mayonnaise sauce. According to Professor Huxley, there are on the Continent two kinds of crayfish, whereas we have only one, and ours the least valuable of the two. I remember that in Germany we used to value the EdelKrebs much before the Stein-Krebs, and in France the "Écrevisse à pieds blancs" is esteemed much less than the larger "Écrevisse à pieds rouges."

Some years ago I read an account in a German fishing paper of a great war which was said to be going on in Russian rivers between the noble crayfish and the stone or common crayfish, in which the former were being gradually exterminated. It is certain that the crayfish is subject to a very mysterious disease, called "crayfish pest," in Germany, by which it is extirminated in whole districts. Like grouse 
disease, potato disease, and saprolegnia ferax, which has destroyed so many thousands of salmon yearly, and many other diseases called blights, we know little about it, and less how to cure it. In our English rivers crayfish are by no means common, and in those comparatively few in which they were formerly abundant they are now scarce. They are found still in large numbers in the New River, which in part supplies London with water, and were very abundant, and may be so still, in the Stoke Newington reservoirs of the New River Company. I remember one rather curious incident in which these strange little fellows played the chief part. It was one hot afternoon in the sixties. I was fishing from the sloping stone embankment of one of these reservoirs. The fish would not bite, and I was reading on the bank, when I heard a peculiar scratching noise. It went on for some time ; and, on getting up to see the cause of it, I saw that hundreds of crayfish were crawling up out of the water on to the big stones. The noise was caused by their claws as they clambered upon the stones. I say hundreds, but there must have been thousands; for, on walking along the bank, I never saw such a sight before or since, and can only suppose that the 
water, on that particular day, had got too warm for them, and that they came out for a change. As I walked along the bank they clumsily scrambled back.

\section{Mascall and the "Kinges Fisher." \\ A Curious Statement.}

After describing how to catch a kingfisher with bird-lime, Mascall has this note: "Also they say this bird, being dead, if he be hanged up by the bill with a thread in your house where no winde bloweth, his brest will alway hang against the winde, whereby ye maye knowe perfectly in what quarter the winde is at all times both night and day."

\section{THE "DOBCHICKE."}

Our English trout-river keepers are all unmerciful to the dabchick, or "Dobchicke," as Mascall calls it, and not without reason, if he is right. He says : "The Dobchicke will be always commonly on rivers and pooles, and they are nigh as great as the Teales, and are of cullour blacke, and they will commonly dive under the water to take young fish, as I have seene in rivers and brookes." And he then illustrates and describes a peculiar method of taking them, viz.: "The 
fishermen doe use to lay on the water long lines of small threede knit full of little corkes, a handfull a sunder on the line, and cut foure square like bigge dice, and so limed, and will spread the saide line afore them on the water, and then with their boats drive them to the sayd line, and so many are taken."

How often the trout-fisher, coming suddenly round the bend of the stream, has seen what he took to be the ring of a rise, and prepared to float his fly over the spot, when a little black head a few yards lower down bobs up, and he says to himself, "Only a blessed dabchick!"

Mascall gives what are doubtless excellent recipes for making bird-lime, and finishes his most interesting notes with one entitled

"A Pretie Way to Take a Pye.

"Ye shall lime a small threede, a foote long or more, and then tie one end about a piece of flesh so big as shee may flie away withall : and at the other end of the thread, tie a shoe buckle and lay the flesh on a post, and let the threede hang downe, and when she flies away with it the threede with the buckle will wrappe round her, and then she will fall, so ye may take them." 
52 The Reprint of Mascall now Scarce.

At the end of this excellent reprint of Mascall's most interesting book is a useful glossary. This reprint must be getting scarce, for I have not seen one mentioned in any second-hand book catalogue, and an advertisement for one in The Publishers' Circular brought no replies.

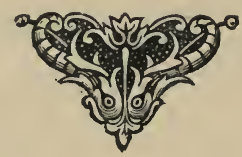




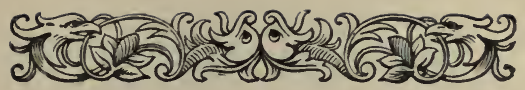

\section{CHAPTER IV.}

Michael Angelo an Angler-La Canna de Piscare -Blakey and the Bibliotheca PiscatoriaMynheer Vandunk.

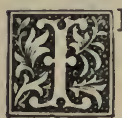

$\mathrm{N}$ I $59^{6 *}$ a black-letter reproduction of The Book of St. Albans, with considerable variations, was published, entitled "Hawking, Hunting, Fowling, and Fishing, with the true measures of blowing, etc., by William Gryndall, now newly collected by IV. G. Faulkner."

In I600 appeared another black-letter quarto, entitled "Certaine Experiments Concerning Fish and Fruite: practised by John Taverner, Gentleman, and by him published for the benefit of others. London, printed for William Ponsonby, I600."

Before coming to "The Secrets of Ang-

* My late friend the Rev. J. J. Manley, M.A., gives the date of publication as 1593 in his pleasant book Notes on Fish and Fishing (S. Low \& Co., 1877). 
ling, by J. D.," which deserves far more notice than can be given to it in this little volume, I should like to direct the reader's attention to a few extracts from Blakey's Angling Literature, an extremely interesting book, now out of print, but not difficult to obtain through the second-hand booksellers. We know that some of our greatest living painters, including Sir John Millais, Mr. John Pettie, R.A.,* and Mr. Orchardson, R.A., are enthusiastic anglers, and I was delighted to find that

\section{Michael Angelo was an Angler:}

that is to say, if the following extract from Blakey's book is correct. The Italian author was evidently a true Waltonian. I mean that, like Dr. Prime, he found far more in fishing than mere fishing :-

"In 17 I 2 we find another Italian publication, of about two hundred and fifty pages, entitled La Canna de Pescare, in which there are some interesting descriptions of angling excursions on some of the higher sections of the river Arno and its smaller tributaries. 'I have travelled much,' says the author, 'with the rod, in certain seasons of the year, by the banks of the chief fishing localities of Italy, and

* Died since these lines were written. 
I feel at all times as if I had made my escape from the ordinary ills and plagues of life. I have commonly had one or two companions, and we have enjoyed ourselves in as lively and rational a manner as possible; giving to Nature all her due, and dwelling on the various picturesque scenes we every day meet with, in that true spirit of admiration so improvable to the heart and understanding. I feel confident that most of our great artists must have been fishers in early life. Our art is well fitted to arouse the dormant powers of sentiment, and the general ideas of the sublime and beautiful in external nature. It is said that Michael Angelo, when a youth, often amused himself with the fishing-rod, and would take long journeys to visit spots famous for their rural scenery and beauties. The same I have heard remarked of less distinguished artists, both sculptors and painters of our own and other countries' (La Canna, p. 6o)." *

* In the Bibliotheca Piscatoria (1883) the only reference to this work is as follows: "Canna. La Canna de Pescare, 1612. (Known to us by title only)." Robert Blakey, whose preface to his Historical Sketches of the Angling Literature of all Nations is dated 1855, evidently knew the book, or we should not have had this delightful extract from it. 
Blakey certainly made some very curious blunders in dates, etc., but I do not think many readers of his work will agree with Messrs. Westwood and Satchell's wholesale condemnation of it in the Bibliotheca Piscatoria as a "slip-shod and negligent work, devoid of all real utility." In his preface he says: "Whatever imperfections, either of commission or omission, which the volume may display, will, I trust, receive some degree of critical indulgence from the fact that this is the first attempt, as far as my knowledge extends, of anything of the kind in any language whatever." $\mathrm{He}$ adds: "I conceive it will prove of interest to all true Piscatorians." It is doubtless well to be precise about dates. I make it a rule to add the date to any undated communication I receive if it is of the slightest importance; but, after all, a date is only a date, and, if for nothing more than his extracts and translations of foreign works referring to fishing, Blakey's book must always be of interest and utility. In all the great list of the Bibliotheca Piscatoria none is mentioned which covers or attempts to cover this ground as he does. His other works, Hints on Angling, The Angler's Complete Guide to the Rivers and Lakes of England, The Angler's Guide to the Rivers and Lochs of Scotland, The 
Angler's Song Book, etc., must always secure for him a place in the affections of those he calls "Piscatorians." At p. 109 of his Angling Literature he says: "The earliest caricatures of the angler we have seen bear the date 1603 . One represents a Dutch amateur, evidently of some public notoriety, sitting like a lubberly clodpole, with the most bewildering expression of face, pulling a prodigious large salmon at the foot of a weir ; in another print figures a fisher weeping for the loss of a part of his rod and tackle. Underneath the print are some verses, which may be paraphrased thus :-

"'Mynherr Vandunk, though he never got drunk, Sipp'd brandy and angled gaily;

And he quenched his thirst with two quarts of the first,

Hooking lots of fine salmon daily:

Singing, "Oh that a fisherman's draught could be

As deep as the rolling Zuyder Zee!"

"'Water well mixed with spirit good store,

No fisherman thinks of scorning:

But of water alone he drinks no more

Than to help him to bring his fish on shore

Upon the market-stall in the morning.

For a fishing Dutchman's draught should be As deep as the rolling Zuyder Zee."

If this is one of Blakey's "quotations incorrectly given, and of so-called original 
passages the vagueness and uncertainty of which rob them of all weight and value," according to Messrs. IVestwood and Satchell, all I can say is, "Si non e vero e ben trovato!"

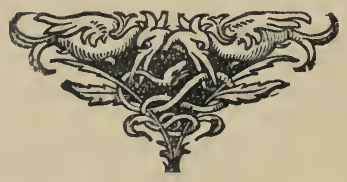




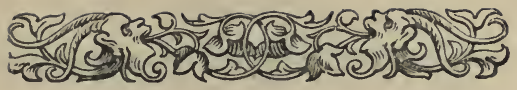

\section{CHAPTER V.}

John Dennys' delightful Secrets of Angling, I6I3 - Some Account of the Book and its Author -A Parenthetical Reference to Multiplying Reels and Sir Humphry Davy's SalmoniaThe Secrets compared with Dame Berners' Treatyse-Quotations from the SecretsAngling in the Age of Wood, of Gold, of Silver and Brass-Angling in the Iron Age.

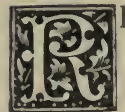

EFERRING the reader for further notices of Continental angling literature of this period to Blakey's book, I come back to England and the year I6I3, when "The Secrets of Angling, by J. D.," first saw the light. For nearly two centuries it was not clearly known who was the author of this, in my humble opinion, most charming poem in all our English angling literature, and we are greatly indebted to the authors of the Bibliotheca Piscatoria for their very full account of it and its various editions, and of such particulars of its author as are 


\section{Dennys' "Secrets of Angling."}

known, which I, with full acknowledgment to them, quote as follows :-

"This poem is also noticed, with large citations, in an article in the Censura Literaria, I809, vol. x., p. 266, which was appropriated by Daniel * and inserted in the supplement to his Rural Sports, I8I3. Its authorship was set at rest in I8II, by the evidence of the books of the Stationers' Company, in which the work is entered as being by JoHN

* On referring to my copy of the Rev. W. B. Daniel's Rural Sports, I find I am able to supply an omission in the Bibliotheca Piscatoria, which makes no mention of the edition I have-Royal 8vo, printed for Longman, Hurst, Rees, \& Orme, Paternoster Row, 1807; also to correct an American angling writer, Mr. A. Nelson Cheney, who, in one of his pleasant angling Notes in Forest and Stream; or, Shooting and Fishing, January 1893 , claims that the multiplier reel was invented in America about the year I820. In this 1807 edition of Daniel's Rural Sports, not the first edition of the work, there is a fine engraving of a brass multiplying reel. I have no doubt multiplying reels were in use much earlier than this. In 1770 Onesimus Ustonson advertised that he sold "the best sort of multiplying brass winches, both stop and plain"; he also advertised "superfine silkworm gut, no better ever seen in England, as fine as hair, as strong as six, the only thing for trout, carp, and salmon." The first mention I have found of the use of a reel at all is in Barker's Delight, 1651. 
Dennys, Esquire. Sir Henry Ellis gives the extract (from the books of the Stationers' Company) in his edition of the poem published by B. Triphook, London, I 8I I."

The entry in the registers of the Stationers' Company is quoted in Mr. Thomas IVestwood's very interesting "Introduction" to his edition of the Secrets, published by W. Satchell \& Co., as follows :-

"I6I 2, Feb. 28th.* Mr. Roger Jackson entered for his copie under th'andes of Mr. Mason and Mr. Warden Hooper, a booke called The Secrets of Angling, teaching the choycest tooles, baites and seasons for the taking of any fish in pond or river, praktised and opened in three bookes, by John Dennys, Esquire. vjd."

Roger Jackson was also one of the publishers of Gervase Markham's Countrey Contentments, etc. Among other of his works, I have one dated the same year as The Secrets of Angling, viz. 16r3, with this imprint:-

"Printed at London by I. B. for R. Jackson, and are to be sold at his Shop neere Fleete-Streete Conduit. I6I3."

* According to others, March 23rd. 
62 The Real Author of the "Secrets."

"Walton" (continues Mr. Westwood) "had previously ascribed the Secrets to John Davors, and others (Howlett among them) to Donne and Davies. The volume contains commendatory verses signed 'Io Daues,' and is dedicated by the stationer R. J. to Mr. John Harborne, of Tackley, in the county of Oxford.

"Beloe says of the book that 'perhaps there does not exist in the circle of English literature a rarer volume.' Sir John Hawkins confessed 'he could never get a sight of it.'

"There is every reason to suppose that Mr. John Dennys, who is shown by the pedigree of the Dennys family to have died at Pucklechurch, Gloucestershire, in I6o9, is the real author of the Secrets, not the grandson of Sir Walter Dennys, put forward for that honour by Sir Harris Nicolas. No date is associated with Sir Walter Dennys, but, on referring to a more detailed pedigree from the same source, it appears that his eldestson, 'Sir William Dennys,' founded a guild in the year 1520 . We may therefore reasonably assign his birth to the latter part of the fifteenth century, or to the very beginning of the sixteenth. These premises are borne out by the fact that John, his second brother (author of the Secrets, according to Sir 
Harris Nicolas), left a son, Hugh Dennys, who died in 1559, and at no immature age, since he was married, and had four offspring. If, therefore, Sir Harris Nicolas's assumption be correct, we must ascribe the poem to the early part, at the latest to the middle, of the sixteenth century, whereas its style and general character belong assuredly to a later period.

"Collateral evidence is to be found in the fact that R. J. (Roger Jackson), in his dedication, does not throw the poem far back, in a posthumous sense, but merely says : 'This poem being sent unto me to be printed after the death of the author, who intended to have done it, in his life, but was prevented by death,' etc."

The Bibliotheca Piscatoria then quotes a long and appreciative notice of the poem by $\mathrm{T}$. Westwood, published in The Angler's Note-Book, r880, pp. I8I-85, from which I shall take but a short extract :-

"It is not needful that I should enter into a critical appreciation of this little poem, the finest passages of which are well known and highly esteemed. Thus much, however, may be said, that, so replete is it, in its higher moods, with subtlety of rhythm, sweetness of expression, and elevation of thought and feeling, 
that, even from the angling point of view, ze cannot but consider it a notable piece of condescension, and marvel at the devotion of so much real poetic genius to a theme so humble. With the exception of The Compleat Angler, no higher compliment than this poem has been paid to the sport."

The italics in the quotation are mine; and surely all anglers will agree with me that from any point of view our sport and art can be considered "humble" is absurd. The truth is, that the compilers of the Bibliotheca Piscatoria were literary rather than practical anglers: they fished very successfully in the tributaries as well as in the main stream of bibliographical research. We must ever be deeply indebted to them for carefully collected particulars about the dates, sizes, editions, etc., of books on angling, but their criticisms of angling works and angling writers were not always just. For instance, what angler will agree with the remark that Sir Humphry Davy's Salmonia "lacks freshness of heart"? This work was written as a recreation by the author "during some weeks of severe and dangerous illness, when he was wholly incapable of attending to more useful studies, or of following more serious pursuits. They constituted 
"Salmonia" and "Bib. Piscatoria." 65

his amusement in many hours which otherwise would have been unoccupied and tedious.... The conversational manner and discursive style were chosen as best suited to the state of health of the Author, who was incapable of considerable efforts and long-continued attention."

Any one who has read Sir Humphry Davy's Menoirs, by his brother, John Davy, M.D., F.R.S., will see that the Salmonia is made up of his own experiences, and that the conversations between Halieus, Poietes, Physicus, and Ornither are reflections of his own varying moods, when, in search of health, he wandered alone among the glorious scenery of the rivers he loved so well, both in this country and on the Continent.* Many of the passages in the Salmonia are transferred almost bodily from his Journal, with the omission of those constant references to his bodily sufferings with which his Journal abounds. "How," he says, in one entry, "I shall enjoy these glorious mountains! But I have a furred tongue

* "Halieus" is supposed to be an accomplished fly-fisher; "Ornither" is a gentleman generally fond of the sports of the field; "Poietes is an enthusiastic lover of nature ; and "Physicus" is the philosopher. 
66 "Nelson was a Good Fly-Fisher."

and a pulse at ninety-six. ... I know not what my fate will be." In another pathetic entry he says : "Dubito fortissime restaurationem meum, as I have so often alluded to the possibility of my dying suddenly, I think it right to mention that I am too intense a believer in the Supreme Intelligence, and have too strong a faith in the optimism of the system of the universe, ever to accelerate my dissolution. The laurel water, therefore, which I have carried about with me, and used constantly, and from which I have decidedly derived benefit, is a prescription of Tomasini's ; and the laudanum and opium which are in my dressing-case, but which $I$ have never used, were recommended to me in small doses to remove irritation, taken with purgatives. I have been, and am, taking a care of my health, which, I fear, it is not worth; but which, hoping it may please Providence to preserve me for wise purposes, I think my duty."

His reference to "duty" reminds me that, in his Salmonia, Sir Humphry says : "Nelson was a good fly-fisher, and, as a proof of his passion for it, continued the pursuit even with his left hand. I have known a person who fished with him at Merton, in the Wandle. I hope this cir- 
"J.D." and" The Secrets of Angling." 67

cumstance will be mentioned in the next edition of that most exquisite and touching Life of our hero by the Laureate,* an immortal monument raised by Genius to Valour."

Although I venture to think the form in which the Salmonia is cast, that of imaginary conversations, is not so successful in the hands of Sir Humphry as in those of his acknowledged prototype, Walton, just as Cotton is behind his master in the same style, still it is not certainly freshness of heart that the Salmonia lacks. What it does lack, it seems to me, is just that "genius" which, as I shall show further on, a great American writer, James Russell Lowell, denies to Walton. He might as well have denied it to Bunyan; for if The Compleat Angler and The Pilgrim's Progress lack genius, whatever that may be, how can one account for the ever-increasing love of them, as generation after generation of men passes away?

To return to "J. D." and his Secrets of Angling, probably the best account of it will be found, as I have already noted, in the late Mr. T. Westwood's

* Southey. In Nelson's letters are to be found frequent references to the fish and fishing at Merton.-R. B. M. 
68 Modern Reprints of the "Secrets."

"Introduction" to his edition of the work, certainly one of the best reprints we possess, inasmuch as it is " a strictly faithful and literal transcript of the edition of r6r3."

Another pretty little reprint was published by E. and G. Goldsmid, of Edinburgh, in 1885 . It was edited by "Piscator," who added some useful notes. Who "Piscator" is I do not know, but we are indebted to him also for the charming reprint of the Treatyse of Dame Juliana Berners, to which I have already referred. Of Mr. Arber's reprint in his English Garner Mr. IVestwood speaks somewhat severely. "Mr. Arber," he says, "has thought it expedient to make many changes in the poem, and to introduce into it frequent supposed emendations. . . He has altered the punctuation throughout, and modernised both the orthography and the syntax, robbing the verse, thereby, of much of its ancient air and aspect." $\mathrm{He}$ adds: "How far we have a right so to interfere with poets who are no longer here to defend themselves and to protect their own-how far it is justifiable to submit them to our individual and arbitrary, not to say dogmatic judgment, is a question we do not take on ourselves to decide." 
The "Secrets" and the "Treatyse." 69

The title-page of the first edition runs thus :-

THE

\section{SECRETS OF ANGLING.}

TEACHING

THE CHOISEST TOOLES

BAYTES AND SEASONS, FOR THE TAKING OF ANY FISH, IN POND OR RIVER:

PRACTISED AND FAMILIARLY OPENED

IN THREE BOOKES.

By J. D. ESQUIRE.

Printed at London, for Roger Jackson, and are to be sould at his Shop neere Fleet Street Conduit, 1613.

In comparing, as I have carefully done, The Secrets of Angling with $A$ Treatyse of Fysshynge wyth an Angle, it is not evident, I think, that John Dennys knew Dame Juliana's work. In some respects the Secrets are not to be compared with the Treatyse for value of information given as regards, for instance, the best of all fish- 
ing-fly-fishing. Dennys, who wrote at least a hundred years after Dame Juliana, seems to have known little or nothing about fishing for salmon, trout, etc., with an artificial fly. I say artificial because he certainly refers to dibbing with a natural fly in his directions for taking the chub and trout. But Dame Juliana gives us most excellent directions for the making of artificial flies for the different months. To her belongs the honour of telling us first that the noble salmon may be taken with a fly. She says :-

"Also ye may take hym but it is seldom seen with a dubbe at such tyme as when he lepith in lyke fourme and manere as ye doo a trought or a graylynge."

Again, value for value, Dame Juliana is far ahead of Dennys as regards instructions for making rods, lines, hooks, floats, etc.

But if Dennys is not so advanced as one might expect in the practical details of angling, he is far ahead of all other English angling writers who have attempted to describe the art in verse. In the first line of his "first booke" he tells us

"Of Angling, and the Art thereof I sing." And in the second verse we have this 
charming invocation to the water nymphs to lend their aid and power to his verse :-

"You Nymphs that in the Springs and Waters sweet,

Your dwelling have, of every Hill and Dale, And oft amidst the meadows greene doe meet To sport and play, and heare the Nightingale; And in the Rivers fresh doe wash your feet, While Prognes* sister tels her wofull tale : Such ayde and power unto my verses lend As may suffice this little worke to end."

Then follow directions as to the best time of year to select and cut woods for rods : of these he prefers the hazel.

"For not the brittle Cane, nor all the rest, I like so well, though it be long and light, Since that the Fish are frighted with the least Aspect of any glittering thing, or white :

Nor doth it by one halfe so well incline, As doth the plyant rod to save the line."

Anglers have ever been particular as to the shape of hook they prefer-some like a round bend, some an oval, some a mixture of square and round, and other variations of in-turned point, out-turned point, side twist, or "sneck," etc. These various shapes are named after the places at which they were originally made;

* Procne's sister Philomela. Procne was turned into a swallow and Philomela into a nightingale. 


\section{His Favourite Shape for a Hook.}

hence we have "Limerick," "Kendal," "Carlisle," etc. It would probably puzzle a hook-maker to make one of Dennys' favourite "Pegasus" pattern, as thus described by him :-

"That Hooke I love that is in compasse round, Like to the print that Pegasus did make, With horned hoofe upon Thessalian ground; From whence forthwith Pernasses spring out brake.

That doth in pleasant Waters so abound : And of the Muses oft the thirst doth slake,

Who on his fruitfull bankes doe sit and sing

That all the world of their sweet tunes doth ring."

Our author continually cautions his reader against using any bright or white colours either in his tackle or his dress : even if you have to mend your rod, it should not be done with white thread. His excellent advice respecting the angler's dress has often been quoted:-

"And let your garments Russet be or gray,

Of colour darke, and hardest to descry:

That with the Raine or weather will away,

And least offend the fearefull Fishes eye."

After recounting the objections which "some youthfull Gallant" may advance against the art, and comparing the vanities of town enjoyments with those of the angler, he says :- 
"I count it better pleasure to behold

The goodlie compasse of the loftie Skye, And in the midst thereof like burning gold The flaming Chariot of the World's great eye ; The watry cloudes that in the ayre uprold With sundry kindes of painted collours flie : And fayre Aurora lifting up her head, And blushing rise from old Thitonus bed.

"The Hills and Mountains raised from the Plaines,

The Plaines extended levell with the ground, The ground divided into sundry vaines, The Plaines inclos'd with running rivers rounde, The Rivers making way through nature's chaine

With headlong course into the sea profounde:

The surging sea beneath the valleys low,

The valleys sweet, and lakes that lovely flowe.

"The lofty woods, the forrests wide and long, Adorned with leaves and branches fresh and greene,

In whose coole bow'rs the birds with chaunting song,

Doe welcome with their quire the summers Queene,

The meadowes faire where Flora's guifts among,

The silver skaled fish that softlie swimme,

Within the brookes and Cristall watry brimme.

"All these and many more of his creation, That made the heavens, the Angler oft doth see, And takes therein no little delectation, To think how strange and wonderfull they be, 
Framing thereof an inward contemplation, To set his thoughts from other fancies free

And whiles hee lookes on these with joyfull eye,

His minde is rapt above the starry skye."

Following these delightful verses, full of the pure spirit of poetry, we have what I think is the finest part of his work-viz., a history of angling through the different ages :-

"But how this Art of Angling did beginne, And who the use thereof and practise found, How many times and ages since have bin, Wherein the sunne hath daily compast round, The circle that the signes twice sixe are in: And yeelded yearly comfort to the ground, It were too hard for me to bring about, Since Ovid wrote not all that story out."

A fine description follows of the Deluge of Deucalion, when only he and his wife Pyrrha were saved, who being themselves. too old to replenish the world, they consult the Oracle of Themis, and were directed to repair the loss of mankind by throwing. behind them the bones of their grandmother :-

"For long before that fearful Deluge great, The universall Earth had overflowne;

A heavenly power there placed had her seate, And answeres gave of hidden things unknowne. 
Thither they went her favour to intreat,

Whose fame throughout that coast abroad was blowne,

By her advice some way or meane to finde, How to renew the race of humane kind.

"Prostrate they fell upon the sacred ground, Kissing the stones, and shedding many a teare ;

And lowly bent their aged bodies downe Unto the earth, with sad and heavy cheere ; Praying the Saint with soft and dolefull sound That she vouchsafe their humble suite to heare.

The Goddesse heard, and bad them goe and take

Their mothers bones, and throw behind their backe."

After being long perplexed as to the meaning of "this Oracle obscure, and darke of sense," and wondering

"How with so great a sinne they might dispense

Their Parents bones to cast and throw about," they leave the Temple and wander forth.

"And now beholding better every place,

Each Hill and Dale, each River, Rock, and Tree;

And muzing thereupon a little space,

They thought the earth their mother well might be,

And that the stones that lay before their face, To be her bones did nothing disagree :

Wherefore to prove if it were false or true

The scattered stones behind their backs they threw. 


\section{Angling in the Age of Wood.}

"Forthwith the stones (a wondrous thing to heare)

Began to move as they had life conceiv'd, And waxed greater than at first they were ; And more and more the shape of man receiv'd, Till every part most plainly did appeare,

That neither eye nor sense could be deceiv'd :

They heard, they spake, they went, and walked too,

As other living men are wont to doe.

"Thus was the earth replenished anew

With people strange, sprung up with little paine,

Of whose increase the progenie that grew, Did soone supply the empty world againe; But now a greater care there did insue How such a mightie number to maintaine, Since foode there was not any found,

For that great flood had all destroyed and drownd."

Invention of the ARt of Angling. The Age of Wood.

The art of angling was now invented to save the newly created inhabitants of the world :-

"Then did Deucalion first the Art invent

Of Angling, and his people taught the same ; And to the Woods and groves with them he went

Fit tooles to finde for this most needful game; There from the trees the longest ryndes they rent,

Wherewith strong Lines they roughly twist and frame, 
And of each crooke of hardest Bush and Brake, They made them Hooks the hungry Fish to take."

Every angler has experienced the difficulty of catching fish without bait ; but old Deucalion was equal to the occasion. $\mathrm{He}$ knows the fish are there :-

"And to intice them to the eager bit, Dead frogs and flies of sundry sorts he tooke; And snayles and wormes such as he found most fit,

Wherein to hide the close and deadly hooke : And thus with practise and inventive wit, He found the means in every lake and brooke Such store of Fish to take with little paine, As did long time this people new sustaine."

$$
\text { Angling in the Age of Gold. }
$$

"In this rude sorte began this simple Art, And so remain'd in that first age of old, When Saturne did Amaltheas horne impart Unto the World, that then was all of Gold ; The Fish has yet had felt but little smart, And were to bite more eager, apt, and bold : And plentie still supplide the place againe Of woefull want, whereof we now complaine." *

* Anglers, like farmers, are good grumblers. We have seen in a previous chapter how Leonard Mascall laments the bad case into which angling had fallen in his day. Dennys does the same, and so it goes on down to our time. We all know many a laudator temporis acti among our angling friends. 
"But when in time the feare and dread of man Fell more and more on every living thing, And all the creatures of the world began To stand in awe of this usurping King, Whose tyranny so farre extended than That Earth and Seas it did in thraldome bring ;

It was a worke of greater paine and skill, The Wary Fish in Lake or Brooke to kill."

\section{Angling in the Age of Silver and Brass.}

"So worse and worse two ages more did passe, Yet still this Art more perfect daily grew, For then the slender Rod invented was, Of finer sort than former ages knew, And Hookes were make of silver and of brasse, And Lines of Hempe and Flax were framed new,

And sundry baites experience found out more, Than elder Times did know or try before."

$$
\text { Angling in the Iron Age. }
$$

But at the last the Iron age drew neere, Ot all the rest the hardest, and most scant, Then lines were made of Silke and subtile hayre, And Rods of lightest Cane and Hazell plant, And Hookes of hardest steele invented were, That neither skill nor workmanship did want, And so this art did in the end attaine Unto that state where now it doth remaine."

And so we come to the end of the " first booke " of Dennys' Secrets of Angling, and to the end of the, to me, perhaps most interesting part of it. The second book is a description in verse of what 
Dame Juliana had already given us more than a century earlier, and more completely: viz., a description of the various kinds of fresh-water fish ; their seasons; how, when, and where to take them; the different "bayts" to be used, etc. The last verse of this book runs thus :-

"Thus have I shew'd how Fish of divers kinde

Best taken are, and how their bayts to know ; But Phoebus now beyond the westerne Inde, Beginneth to descend and draweth low, And well the weather serves and gentle winde Downe with the tide and pleasant streame to row,

Unto some place where we may rest us in, Untill we shall another time begin."

\section{Dennys' "ThiRd BOOKE."}

In this we again leave the practical and less poetic side of angling, and find some charming pictures of the angler's recreation, and of the qualities which a good angler should possess, of which there are twelve, not the least of them being Patience.

"For there are times in which they will not bite."

And the angler is described in a charming metaphor as being at times like a vessel waiting for a favourable wind :-

"And as a ship in safe and quiet roade Under some hill or harbour doth abide, 


\section{8o The "Qualities of an Angler."}

With all her fraight, her tackling, and her load Attending still the winde and wished tide, Which when it serves, no longer makes abode, But forth into the watry deepe doth slide,

And through the waves divides her fairest way

Unto the place where she intends to stay.

"So must the angler be provided still,

Of divers tooles, and sundry baytes in store; And all things else pertaining to his store ;

Which he shall get and lay up long before,

That when the weather frameth to his will,

He may be well appointed evermore

To take fit time whan it is offered ever,

For time in one estate abideth never."

Very charming and musical in Dennys' verses are the two last lines of each, forming, as they often do, a refrain or burden of the whole. Much as I should like to quote the whole of the twelve "qualities of an angler," I must, for want of space, confine myself to one or two. One might imagine that Dennys knew what it was to stalk a wary Test or Itchen trout on a bright day in June, to judge from the following verse describing his fifth quality:-

"The fifth good gift is low Humilitie, As when a lyon coucheth for his pray So must he stoope or kneele upon his Knee, To save his line or put the weeds away, Or lye along sometime if neede there be, For any let or chance that happen may, And not to scorne to take a little paine, To serve his turne his pleasure to obtaine." 


\section{“A Merry Carroll Sing." $\quad 8 \mathrm{r}$}

I fear few modern anglers can lay much claim to possess the "eleventh gift of a good angler." Even Dennys called it the " hardest to endure"; but much depends on what he calls "superfluous fare":-

"The eleventh good gift and hardest to indure, Is fasting long from all superfluous fare, Unto the which he must himself inure, By exercise and use of dyet spare, And with the liquor of the waters pure, Acquaint himselfe if he cannot forbeare, And never on his greedy belly thinke From rising sunne untill a low he sincke."

With one more quotation from these Secrets I must leave Dennys : it is his last verse :-

"And now we are arrived at the last, In wished harbour where we meane to rest; And make an end of this our journey past ; Here then in quiet roade I thinke it best We strike our sailes and stedfast Anchor cast, For now the Sunne low setteth in the West, And yee Boat-Swaines, a merry Carroll sing To him that safely did us hither bring." 


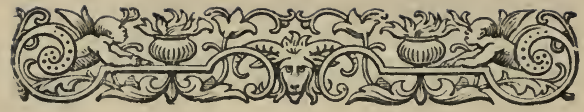

\section{CHAPTER VI.}

Gervase Markham's Art of Angling (1614) and other Books-His Work not merely a Prose Version of The Secrets of Angling-William Lawson, a North-Country Angler and Writer -Barker's Delight-Thomas Barker, a Firstrate Trout-Fisher-Walton's Indebtedness to Him-The First Writer to Describe the Use of the Reel or Winch and the Gaff in Salmon-Fishing-His Directions for FlyMaking and Fly-Fishing.

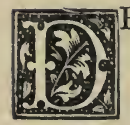

ENNYS' own work, as originally printed in verse, is one of the rarest books in the English language; but this did not detract from its value as a text-book, inasmuch as it was reprinted as a poem several times, and, in part, in prose editions under other titles, chiefly in connection with the works of that interesting and prolific writer and compiler Gervase Markham.

The original poem was first published in $161_{3}$, and it is curious to note that what the editors of the Bibliotheca Pisca- 
toria call a "prose version" of it appeared next year in the second part of The English Husbandman, drawne in Two Books, by Gervase Markham. I have in my possession original copies of several of Markham's books, including a fine example of the 1631 thick quarto edition, which contains most of them under the general title $A$ Way to get Wealth, in six books. "I. Cheape and Good Husbandry. II. Country Contentments, including Hunting, Hawking, Coursing with Greyhounds, Shooting in Longbow* or Crossbow, Bowling, Tennis, Baloone, THE WhOlE ART OF ANGling, the use of the Fighting Cock. III. The English Housewife, 'containing the Inward and Outward Vertues which ought to be in a Compleate Woman.' IV. The Enrichment of the Weald of Kent. V. Markham's Farewell to Husbandry. VI. A new Orchard and Garden, including the Husbandry of Bees." Of these six books it is said, "The first five Bookes gathered

* Archers might well wish that he had devoted a good deal more space to a description of this fascinating exercise. By the way, he says the bow-string should be drawn by holding it with the thumb as well as the fingers. As far as I know, no other writer on archery recommends the use of the thumb.-R. B. M. 
by Gervase Markham, the last by William Lawson."

This most delightful old book, with its quaint woodcuts, has given me many an hour's enjoyment. Part VI., by William Lawson, should be read by every lover of orchards, bees, and gardens.

I am not aware that it has been previously pointed out that "The Whole Art of Angling " contained in this volume is not exactly what the editors of the Bibliotheca Piscatoria call it-viz., a prose version of The Secrets of Angling. Thanks again to my angling friend, Mr. W. B. Adlington, who was fortunate enough to pick it up at a second-hand bookseller's shop for the price "of an old song," I have been able to examine a copy of the first edition of his " prose version," which, as I have already stated, was published in 16I4 with Markham's Pleasures of Princes. This very perfect and beautifully printed black-letter edition contains "A Discourse of the generall Art of Fishing with the Angle, or otherwise, and of all the hidden secrets belonging thereunto," together "with the Choyce, Ordering, Breeding, and Dyetting of the fighting Cocke."

It is pretty clear to me that this prose work on angling of I6I4 was compiled 


\section{The Stone Fly.}

by Markham, or by Lawson for Markham, from, not merely the Secrets, but also from the Treatyse and from Leonard Mascallprobably from Mascall and Dennys. Take, for instance, from the directions for making artificial flies one example,-and many a dish of fine trout have I killed in Yorkshire with the fly described.

Dame Juliana Berners, i496.

The Stone Fly._- "The Stone flye, the bodye of blacke wull; and yellow under the wynge, and under the tayle and the wynges of the drake."

\section{LeONARI Mascall, $159^{\circ}$.}

The Stone Fly._. "The body is made of blacke wooll, made yellow under the wynges and under the tayl, and so made with the winges of the drake."

Gervase Markham: "The Art of ANGLING," I6I 4.

"The Stone fly is made of blacke woll, made yellow under the wings, and under the tayle with silke, and the wings of drakes downe."

I think Dame Juliana's claim to be the first to give a dressing of this most deadly 
86 The Fly-Maker should Copy Nature.

fly will not be disputed. Of course as time went on anglers improved in their imitations, and we find in Markham's book, in 1614 , the advantages of cork as a material for fly-dressing recommended :-

"Now for the making of these flyes, the cloudie darke flye is made of blacke wool, clipt from between a sheepes ears, and whipt about with black silke, his wings of the under mayle of the Mallard, and his head made blacke and sutable, fixed upon a fine piece of cork, and folded so cunningly about the hooke, that nothing may be perceived but the point and beard onely."

These directions are not particularly clear, but it looks as if the foundation of the body was to be cork.

Here is a bit which will interest flyfishers from The Art of Angling:-

"Now for the shapes and proportions of these flyes, it is impossible to describe them without paynting, therefore you shall take of these severall flyes alive, and laying them before you, trie how near your Art can come unto nature by an equall shapes and mixture of colours; and when you have made them, you may keep them in close boxes uncrushed, and they will serve you many yeares."

As I have already said, this work can 
hardly be called a prose version of the Secrets; it consists of two or three only of the chapters of that work, with some from Leonard Mascall's book, and a few additions given apparently from the practical experience of the compiler.

\section{William Lawson, Angler and IVRITER.}

It is uncertain who made this compila tion in I6I4, whether Markham himself or Lawson for him; but about 1620 a second edition of the Secrets in verse, with notes by William Lawson, appeared, and in the complete edition of Markham's Cheape and Goode Husbandry, published in I63I, called on the title-page "Fifth Edition," we find the sixth book, "On the Orchard, Garden, Bees, etc.," is by William Lawson. In his dedication to Sir Henry Belosses, Lawson mentions his " 48 yeeres (and moe) experience in the North of England," so that he was probably a North-countryman. His very practical additions to the Secrets, and his " approved experiments," show clearly that he was an angler accustomed to fishing clear North-country streams. The following remark of his reminds one of Cotton's criticism of "southern" tackle :- 
"I utterly dislike your southern corks. First for they affright the fish, in the bite and sight, and because they follow not so kindly the nimble rod and hand. Secondly they breed weight to the line, which puts it in danger, and hinders the nimble jerk of the rod, and loades the arm. A good eye and hand may easily discern the bite."

$\mathrm{He}$ tells us that he makes his own hooks out of the best Spanish and Millan needles, and gives excellent illustrated instructions in the manufacture. With reference to a line in the Secrets, in which Dennys says of the hook,

"His point not over sharp, not yet too dull,"

Lawson says truly, "He meanes the hooke may be too weake at the point, it cannot be too sharpe if the metal be good steele."

Lawson, as far as I know, was the first angling writer to mention that fish of the carp family have throat teeth.

\section{"The Cast of the Flie."}

Of the trout he remarks :-

"The trout makes the angler most gentlemanly, and readiest sport of all other fishes: if you angle with a made fly, and a line twice your rod's length or more (in a plaine water without wood) 


\section{"The Cast of the Flie."}

of three haires, in a darke windy day from afternoone, and have learned the cast of the flie, * your flie must counterfeit the may flie, which is bred of the cod-bait, and is called the water-flie: you must change his colour every month, beginning with a dark white, and so grow to a yellow, the forme cannot so well be put on a paper, as it may be taught by slight" ... [Then follows a rough illustration in which the setæ are represented in a curious manner.]

"The head is of black silk or haire, the wings of a feather of a mallard, teele, or pickled-hen wing. The body of Crewell according to the moneth for colour, and run about with a black haire; all fastened at the taile with the thread that fastened the hook. You must fish in, or hard by the stream, and have a quick hand, and a ready eye, and a nimble rod, strike with him, or you lose him" (i.e., strike at the rise). "If the wind be rough, and trouble the crust of the water, he will take it in the plaine deeps, and then and there commonly the greatest will rise. When you have hookt him, give him leave, keeping your line straight, and hold him

* I believe this is the first time in our angling literature this expression is used, "the cast of the flie."-R. B. M. 


\section{Lawson not Properly Appreciated.}

from roots, and he will tire himself. This. is the chief pleasure of angling. This flie and two linkes among wood, or close by a bush, moved in the crust of the water, is deadly in an evening, if you come close. This is called bushing for trouts."

When this description of fly-fishing for trout with the May-fly was first published is doubtful. The only edition of the Secrets with Lawson's notes which I possess is that of Sir Henry Ellis, I8II, reprinted from the edition of $\mathrm{I}_{52} 2$ (Walton's first edition appeared next year); but there was a previous edition in 1630 , and one before that, "circa I620," according to the Bibliotheca Piscatoria. At any rate to Lawson belongs the credit of the best description of fly-fishing for trout previous to Barker, Walton, and Cotton.

Of "divers wayes to catch the wrinkling eele," he gives very practical directions; in fact, I think Lawson is much more deserving of a place in that Valhalla of angling writers the Bibliotheca Piscatoria than some who figure therein. It will be seen by the following extract that he got in, as it were, only by the skin of his teeth :-

"Lawson (William). A new Orchard and Garden, etc. London, I61 7-8, 1626, etc., 4to. 
' (Admissible, by stress of courtesy, and for the sake of that 'pleasant River with silver streams' that the old writer would fain have in his orchard, and wherein he might 'angle a freckled trout, sleighty eel, or some other dainty Fish')."

\section{"BARKer's Delight."}

Between Lawson and Walton came a quaint and very original little work, Barker's Delight. Old Barker was evidently a first-rate trout-fisher, and his book has special interest for the fly-fisher,* for reasons which I shall presently mention. If Barker had called his work Barker's Angling, or, as he might appropriately enough have done, Barker's Trout-Fishing, it would have attracted much more attention than it has received. An author never makes a greater mistake than when he uses as the leading title of his book some phrase or expression or word which conveys no idea of the contents. It does not matter how full the

* Here is a hint from Barker which may be of assistance to some amateur maker of fishingflies for dry-fly fishing:-

"Once more, my good brother, I'll speak in thy ear ;

Hog's, red cow's, and bear's wool, to float best appear." 
second title may be; hundreds for whom it is intended miss it, passing over the large-type leading title which conveys nothing. Such an ambiguous title, especially when it has no explanatory sub-title, is the bane of the compiler of catalogues, and frequently robs the author of much of the credit to which he is entitled.

Walton freely acknowledges his indebtedness to Barker. When Piscator and Viator are sitting smoking in the shade of the sycamore tree after breakfast, Viator reminds his master of his "promised direction for making and ordering my artificial flye," and to this replies :-

Piscator. "My honest Scholar, I will do it, for it is a debt due unto you, by my promise : and because you shall not think your self more engaged* to me than indeed you really are, therefore I will tell you freely. I find Mr. Thomas Barker (a Gentleman that has spent much time and money in angling) deal so judicially and freely in a little book of his of Angling, and especially of making and angling with a flye for a Trout, that I will give you his very directions without much variation, which shall follow."

* Indebted. 
Barker Born near the Severn. 93

I find that, in his " much corrected and enlarged Fifth Edition," Walton says (I quote from a copy of that edition in my possession): "I shall next give you some other Directions for Flie-fishing, such as are given by Mr. Thomas Barker, a gentleman that hath spent much time in Fishing: but $I$ shall do it with a little variation."

Of Thomas Barker we have some information scattered here and there in his pages. I have before me a charming little reprint given me some years ago by the editor, Mr. C. S. Bentley, F.S.A., of the Gresham Angling Society. Barker tells us that he was born and educated at "Bracemeale in the Liberty of Salop, being a Freeman and Burgesse of the same City." Bracemeal or Brace-meole is a parish in Shrewsbury district, Salop, one mile south of Shrewsbury,* on the river Severn, still one of our finest salmon rivers. Doubtless Barker gained his experience of salmon-fishing on that river; for he is the first writer who writes apparently from actual experience of salmon-fishing, and in those delightful tributaries of the Severn he would have full scope for that fly-fishing for trout

* Impsrial Gazetteer. 
94 First Description of the Winch.

which he knew and loved so well. $\mathrm{He}$ speaks in his "Epistle Dedicatory," in his enlarged second edition, published in r657, of having been threescore years gathering the information, so that he was probably a young man when Walton was born. It is most likely that he was acquainted with Walton, for this second edition was published by Walton's publisher, Richard Marriot, and in it he tells us that "I live in Henry the 7 ths Gifts, the next door to the Gatehouse in Westminster," and offers to give information about fishing to "any noble or gentle Angler" who may desire it.

In addition to having the honour of providing Walton with much of his information in the highest branch of angling, fly-fishing, and giving the first clear but simple directions for fly-making, Barker, so far as I have been able to trace, was the first English writer to mention the use of the winch.

BARKER the First to Describe the USE OF THE REEL OR WINCH AND the Gaff in Angling for Salmon OR OTHER Fish.

Not long since I saw a statement in an angling paper that the use of the winch 
was not mentioned by Walton. This is both true and not true ; it is not mentioned in his first edition, but in others it is.

Page I46, fifth edition, Compleat Angler: "Note also, that many use to fish for a salmon with a ring of wire on the top of their Rod, through which the Line may run to as great a length as is needful when he is hook'd. And to that end, some use a wheel about the middle of their rod, or near their hand, which is to be observed better by seeing one of them, than by a large demonstration of words."

But Barker, who wrote before Walton, not only describes the reel, but gives an illustration of it. This passage is very interesting. He says (p. 18):-

"I will now shew you the way to take Salmon. The first thing you must gain must be a rod of some ten foot in the stock that will carry a top of six foot pretty stiffe and strong, the reason is, because there must be a little wire ring at the upper end of the top for the line to run through, that you may take up and loose the line at your pleasure; you must have your winder within two foot of the bottom to goe on your rod made in this manner, with a spring, that you may put it as low as you please."

(Compare this with the extract just 
96 His Instructions in Salmon-Fishing.

previously given, and it will be clear where Walton got his description of the reel from, though Barker knew too much about it to say it is put on the middle of the rod.)

Barker continues :-

"The Salmon swimmeth most commonly in the midst of the river. In all his travells his desire is to see the uppermost part of the river, travelling on his journey in the heat of the day he may take a bush [i.e., rest in the shade of a bush]; if the fisherman espy him, he goeth at him with his speare, so shorteneth his journey.

"The angler that goeth to catch him with a line and hook, must angle for him as nigh the middle of the water as he can with one of these baits: He must take two lob-worms baited as handsomely as he can, that the four ends may hang meet [evenly] of a length, and so angle as nigh the bottom as he can, feeling your plummet to run on the ground some twelve inches from the hook: if you angle for'him with a flie (which he will rise at like a trout) the flie must be made of a large hook, which hook must carry six wings, or four at least; there is judgment in making these flyes. The Salmon will come at a Gudgeon in the manner of a trouling, and 
cometh at it bravely, which is fine angling for him and good. You must be sure that you have your line of twenty-six yards of length, that you may have your convenient time to turne him, or else you are in danger to lose him : but if you turn him you are very like to have the fish with small tackles: the danger is all in the running out both of Salmon and Trout, you must forecast to turn the fish as you do a wild horse, either upon the right or left hand, and wind up your line as you finde occasion in the guiding of the fish to shore, having a good large landing hook to take him up."

The words italicised are the earliest reference to the use of the gaff which I have noticed in an angling writer. It was not till long after Walton's time that the use of the reel became general.

Barker was also the first writer to divide artificial flies into the two great divisions offlies.

I. Palmer, hackle, or spider-dressed

2. Winged flies.

He says (p. 32): "Now I will shew you how to make flies. Learn to make two flies and make all, that is, the Palmer ribbed with gold or silver, and the Mayflye. These are the ground [or founda- 
tion] of all flyes." He then gives the best and simplest description of how to make artificial flies then extant; it is used in full by Walton, and until Cotton's work appeared may truly be termed "the flyfisher's text-book." Indeed, the more Barker's book is considered from the angler's point of view, the more it impresses itself on one as the work of a thoroughly practical angler, who was in many respects far ahead of his time. Take, for instance, this specimen of his writing :-

"My Lord sent me at Sun going down to provide him a good dish of trouts against the next morning by sixe of the clock. I went to the door to see how the wanes of the air were like to prove. I returned answer, that I doubted not, God willing, but to be provided at his time appointed. I went presently to the river, and it proved very dark, I drew out a line of three silks and three hairs twisted for the uppermost part, and a line of two hairs and two silks twisted for the lower part, with a good large hook: I baited my hook with two lob-worms, the four ends hanging as meet [even] as I could guess them in the dark, I fell to angle. It proved very dark, so that I had great sport angling with the lob-worms as I doe with 
the flye on the top of the water: you shall heer the fish rise at the top of the water, then you must loose a slack line down to the bottom as nigh as you can guess, then hold your line strait, feeling the fish bite, give time, there is no doubt of losing the fish, for there is not one among twenty but doth gorge the bait; the least stroke you can strike fastens the hook and makes the fish sure; letting the fish take a turn or two, you may take the fish up with your hands. The night began to alter and grow somewhat lighter, I took off the lob-worm and set to my rod a white Palmer-flye, made of a large hook; I had sport for the time until it grew lighter, so I took off the white Palmer and set to a Red Palmer made of a large hook; I had good sport until it grew very light. Then I took off the Red Palmer and set to a Black Palmer; I had good sport, made up the dish of fish. So I put up my tackles and was with my Lord at the time appointed for the service.

"These three flies with the help of the lob-worms serve to angle all the year for the night, observing the times as I have shewed you in this night-work, the white flye for darknesse, the red flye in medio, and the black flye for lightnesse. 
This is the true experience for angling in the night, which is the surest angling of all, and killeth the greatest Trouts."

Although old Barker was fishing for his master's breakfast, there is the right ring about his writing. Many a lusty ancestor must he have slain of those admirable fellows of Shropshire, Yorkshire, and most other English shires some of us have had more than a passing acquaintance with.

Not alone was Valton indebted to Barker. Colonel Venables took his Night Angling for trout straight from Barker. I wonder if they ever met and smoked a pipe together-Barker, Walton, and Venables? Richard Marriot published for all of them, and surely they must all have met at his shop in St. Dunstan's Churchyard, Fleet Street.

Barker not only knew how to kill trout, but also how to cook them, and much of his little volume is taken up with instructions of a culinary nature. And uncommonly good they appear to be: take this one example (p. I3); he says :-

\section{"Broyled Trouts.}

"We must have one dish of Broyled Trouts, when the intrails be taken out, you must cut them across the side: being 
washed clean, you must take some sweet herbs, as thyme, sweet marjoram, and parsley chopped very small, the trouts being cut somewhat thick, and fill the cuts full with the chopt herbs, then make your gridiron fit to put them on, being well cooled with rough suet, then lay the Trouts on a charcoal fire : as you turn them baste them with fresh butter untill you think they are well broyled, the sauce must be butter and vinegar, the yolk of an egge beaten, beat all together and put it on the fish for the service."

"The best Trouler for a Pike in England.

"There was one of my name," says Barker, " the best trouler for a Pike within this Realm of England; the manner of his trouling was with a hasell rod some twelve foot long, with a ring of wire in the top of the rod for his line to run through: within two feet of the bottom of the rod there was a hole made to put in a winder to turn with a barrell, to gather up his line and loose it at his pleasure. This was his manner of trouling with a small fish."

And here I will leave this famous old angler and cook, whose little book was 
Io2 Title-P'age of Barker's Book.

first published in $165 \mathrm{I}$, giving a copy of the title-page of his second edition:-

\section{BARKER'S DELIGHT,}

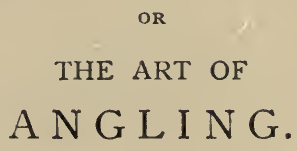

WHEREIN ARE DISCOVERED MANY RARE SECRETS VERY NECESSARY TO BE KNOWN BY ALL THAT DELIGHT

IN THAT RECREATION, BOTH FOR CATCHING THE FISH, AND DRESSING THEREOF.

The Second Edition much enlarged.

\section{BY THOMAS BARKER,} AN ANTIENT PRACTITIONER IN THE SAID ART.

Eccles. iii. I, II.

"There is a time and season to every purpose under Heaven; Everything is beautifull in his time."

London : printed by J. G. for Richard Marriot, and sold at his shop in S. Dunstan's Churchyard, Fleet Street, 1657. 


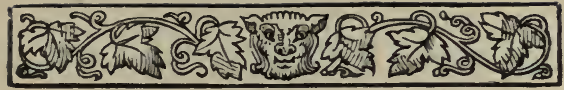

\section{CHAPTER VII.}

Waiton and the World's Fair, I893-A Glance at the Times in which He Lived-Some Account of the Chief Particulars of Walton's Life which have Come Down to Us-No Proof Exists that He was ever a "Sempster, Haberdasher, or Hamburgh Merchant "His Connection with the Ironmongers' Company-His First Marriage-Offices Held by Him in the Parish of St. Dunstan's-in-the West-Loss of His First Wife and Seven Children during His Residence in Chancery Lane-His Second Marriage-His Connections by Marriage with the Cranmer and Ken Families-Birth of His Son IsaacWas Probably Residing in Clerkenwell when His Compleat Angler was First Published-Walton a Staunch Royalist-Incident After the Battle of Worcester-Death of His Second Wife-Lives at the Houses of Dr. Morley, Bishop of Winchester, and Dr. Ward, Bishop of Salisbury-Dies at Winchester, December I 5 th, 1683 .

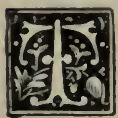

HE other day I had the following letter from an American friend, Dr. James A. Henshall, author of The Book of the Black Bass, who has charge of the Angling 103 


\section{Walton at the World's Fair.}

Department of the great "World's Fair" at Chicago :-

"World's Columbian Commission. Office of the

"Director-General of the Exposition. "ChicAGo, IlL., U.S.A., March 27th, I893.

"Dear Mr. Marston,-There will be a reproduction of Walton and Cotton's fishinghouse on the World's Fair grounds to celebrate the 3ooth anniversary of Izaak Walton's birthday, which occurs August 9th, 1893.

"I would very much like a good photograph of his statue in Winchester Cathedral, in order to have an enlarged print made from it to place in the house. If you can procure a good one, and will mail it to me, I shall be very much gratified, and will cheerfully re-pay you for any expense that you may incur. The fine illustrations of the house in your 'Centennial Edition ' will prove of great assistance in the reproduction of the structure.

"With kindest regards, and in the hope of seeing you this summer,

"I am, yours very truly, "J. A. HENShall,

" In charge Angling Pavilion, Fisheries "Building, Jackson Park, Chicago.

“Mr. R. B. MARSTON,

"Editor Fishing Gazette, London, England."

I of course gladly sent the photograph of the statue, and also others of the fishing-house, of which Cotton says, writing 
Walton at the World's Fair. 105

in March 1676 : "My house stands upon the margin of one of the finest rivers for Trouts and grayling in England. ... I have lately built a little Fishing House upon it, dedicated to Anglers, over the door of which you will see the two first Letters of my Father Walton's name and mine twisted in Cypher as in the title page."

It is certainly pleasing to think that in this greatest of all great world's fairs there is place for and thought for the old angler and biographer. "Red Spinner," who has given us such vivid pictures of the Fair in the columns of The Daily Nerws, describes the general effect as " overwhelming." Pleasant will it be then for the angler to come across this little oasis dedicated to Walton, or, in other words, to peace, contentment, and the love of quiet country life.

But Walton is not out of place at Chicago. Extremes meet; and we have, as it were, a precedent for it in the contrast between Walton's calm life and the turbulent, terrible times in which he lived. As I said in my edition of his work : "It has often appeared strange to me, when reading a chapter or two of The Compleat Angler, that these delightful pictures of the 'contemplative man's recreation,' 
these charming scenes of peaceful, pastoral life, should have been produced by a man who had lived through the horrors of the Civil Wars-sieges, battles, skirmishes, and countless struggles between the Royalist and Parliamentarian forces, in which brother often fought against brother and father against son."

\section{IValton on His Own Times.}

In his admirable Lives Walton gives some stirring pictures of the times in which he lived. In his Life of Dr. Robert Sanderson he says :-

"Some years before the unhappy Long Parliament, this nation being then happy and in peace, (though inwardly sick of being well,) namely in the year 1639 , a discontented party of the Scots Church were zealously restless for another reformation of their Kirk-government; and to that end created a new covenant. . . The Presbyterian party of this nation did again, in the year 1643 , invite the Scotch covenanters back into England: and hither they came marching with it [the covenant] gloriously upon their pikes and on their hats, with this motto: "For the Crown and Covenant of both Kingdoms.' This I saw, and suffered by it. 
"But when I look back upon the ruin of families, the bloodshed, the decay of common honesty, and how the former piety and plain-dealing of this now sinful nation is turned into cruelty and cunning, I praise God that he prevented me from being of that party which helped to bring in this covenant, and those sad confusions that have followed it." *

\section{A Brief Biographical Notice of WALTON.}

Izaak Walton was born on August 9th, 1593, in the parish of St. Mary in the town of Stafford. Of his father, Jervis

* The following extract, from a list, published in 1647 , of the names of officers under command of General Sir Thomas Fairfax, is a grim commentary on Walton's lament: "Major Cook, died before Bristol ; Lieutenant-Colonel Frances, slain at Naseby ; Lieutenant-Colonel Cottesworth, slain before Oxford; Captain Hill, slain before Bristol ; Captain Wilks, slain at Basing; Colonel Lloyd, slain at Taunton; Captain Wigsal, slain at Berkeley Castle; Captain Jenkins, slain at Farringdon, succeeded by Captain Tompkins, slain at Naseby ; Lieutenant-Colonel Ingoldesby, slain at Pendennis; Major Cromwell, slain at Bristol," etc., etc. Our ancestors meant business when they fought; at Edgehill they killed about three thousand of each other, or six thousand in one day - a tremendous proportion of the small armies engaged. 
Walton, little is known; he died about three years after Walton was born. Of his mother not even the name has been discovered, and it is doubtful whether she survived her husband. There appears to be no proof whatever for Dr. Zouch's statement in his Life of Walton that his mother was the daughter of Edmund Cranmer, Archdeacon of Canterbury.

Walton received a fair education, probably at the Grammar School of his native town; and though there is no record of his life from the date of his baptism until we find him in London in 1618, it is fair to infer that his first angling experiences were probably as a youngster at Stafford, wandering with some congenial spirit along the banks of the neighbouring streams, armed with hazel rod and horse-hair line.

Sir Harris Nicolas says the first reference to Walton when a young man is in the dedication of a short poem entitled The Love of Amos and Laura, by S. P.,* published in 1619 (the year before The Mayflower sailed for New England), to which attention was first drawn by $\mathrm{T}$. Payne Collier in The Poetical Decameron, vol. ii., p. III.

A fact which seems to have escaped * Samuel Purchas. 
the notice of that most careful and in defatigable of all Walton's biographers, Sir Harris Nicolas, appears to me to prove that Walton came to London prior to $\mathrm{I}^{6} \mathrm{I}_{3}$, the earliest date mentioned by Sir Harris. The records of the Ironmongers' Company show that on November I2th, I6I8, Walton, who is described as late apprentice to Mr. Thomas Grinsell, was made a member of that company. This would seem to indicate that Walton began life in London as an apprentice when he was about sixteen years of age-i.e., about the year I6II. The statement of Sir John Hawkins that Walton's first settlement in London as a shopkepeer was in the Royal Burse in Cornhill, built by Sir Thomas Gresham, in 1616 , is not supported by proof of any kind; nor is there any evidence to show that he was ever a sempster, haberdasher, or Hamburgh merchant, as stated by most of his biographers, while there is direct evidence that he was engaged in a tofally different business.

The records of the Ironmongers' Company, as already mentioned, prove that he was made a member of that company on November I 2 th, 1618. It does not follow as a matter of course that Walton was an ironmonger by trade because he was 
a member of the Ironmongers' Company ; but in his marriage licence with Rachel Floud, dated December 27 th, 1626 , he is described as of the "Cittie of London, Ironmonger." Surely, if he had been a sempster or haberdasher, he would not have called himself an ironmonger?

"No circumstance," says Mr. Nicholl, F.S.A., in his History of the Ironmongers' Company, "has given me more gratification than the discovery that Izaak Walton is enrolled among their members." The records of the company give other interesting facts about Walton. We find that "he served as a gentleman in foins in the mayoralty of Sir Thomas Campbell in 1629 , and performed the like service in 1635, in the pageant provided for Sir Christopher Clitherow."

In 1637 Walton - was chosen Warden of the Yeomanry, and in 1639 paid over to his successor the sum of $£^{2} 7 s$. rod., the balance left in his hands after discharging the duties of that office. He is again mentioned in 164I, the Lord Mayor having addressed three several precepts to the city companies,-requiring them, in the first place, to make a return of all their members, with their several places of abode ; secondly, to collect the moneys rated upon them respectively by Act of 


\section{Walton's First Marriage. I I I}

Parliament ; and, lastly, to signify that the sum of $£ 40,000$ was immediately required for the important affairs of the kingdom. Whereupon the Ironmongers were severally assessed for this purpose, and Walton appears in the list of Yeomanry, and is there described as "Isaacke Walton of the Parish of St. Dunstan's in the West," his contribution amounting to the sum of $£ 3$.

Beyond this we find no further mention of him in the Records, except in an account of arrears of quarterage. From this it may be inferred that his residence was not then known to the officers of the company.

On December 27th, 1626, IValton was married to Rachel Floud in the parish church of St. MiIdred at Canterbury. Respecting his first residence in London, Sir John Hawkins states, on the authority of a deed in his possession, that in 1624 "Walton dwelt on the north side of Fleet Street, in a house two doors west of the end of Chancery Lane, and abutting on a messuage known by the sign of the Harrow," and that this house was then in the joint occupation of himself and a hosier called John Mason. It appears from the parish books of St. Dunstan's that from $I 628$ to 1644 his residence was in Chancery Lane, "about 
the seventh house on the left-hand side," that he filled a parish office in December 1632 ; served on the jury in 1633 ; was appointed a constable on December 2oth, 1636 ; was again on the grand jury in 1638 ; was one of the overseers of the poor in and a sidesman on April 18th, 1639; and a vestryman in February 1640 . He continued to reside in Chancery Lane until about August r644. He was appointed examiner of St. Dunstan's August 27th, I64 I, was elected a vestryman in 1644 ; but at a vestry holden on August 2oth in the same year another person was chosen "in the room of Isaak Walton lately departed out of this parish and dwelling elsewhere."

From $\mathrm{I} 644$ to $\mathrm{I} 65 \mathrm{I}$ there is some uncertainty as to where Walton lived. Anthony Wood, the Oxford antiquary, tells us that, "finding it dangerous for honest men to be there, he left that city [London], and lived sometimes at Stafford; but mostly in the families of the eminent clergymen of England, of whom he was much beloved."

While making some inquiries at Stafford about Walton's connection with that town, the most interesting relic I came across was a note by him referring to his house and land at Shallowford (of which note I have given a facsimile copy 
in my edition of the Angler). From this note, dated October 23 rd, I676, it appears that Walton bought the property in 1656 , and had "had peaceable possession of it twenty-two years."

IValton's description and bequeathal of this property are given in his will. $\mathrm{He}$ left it to his son Izaak, and in the event, as happened, of his death without issue to the corporation of Stafford, "for the good and benefit of the said town." *

Hearing later from the Mayor of Stafford that he had been obliged to abandon the

* Proposed Memorial of Walton in London.

Since these lines were written the Mayor of Stafford has consulted me with respect to the celebration in this country of the tercentenary of Walton's birth. On a previous page I have referred to what they propose to do in America. $\mathrm{He}$ said that Mr. Andrew Lang had been asked to preside at a banquet, but was unable to accept, as he would be far away at the time. I suggested that we need not go far for a chairman. Seeing that it was Walton's birth at Stafford we wished to celebrate, what could be more appropriate than that the Mayor of Stafford should preside? And I was certain he would be well supported, especially if the affair took place in or near London. I also said that I had been thinking over the matter for some time, and it appeared to me that we ought to mark the occasion by something more permanent than a banquet; that, whereas the place of Walton's 
idea of any celebration of the tercentenary at Stafford, it was decided to hold an informal celebration of the event at Broxbourne, on the Lea. Delegates from the principal London angling associations and other visitors were present at a pleasant gathering of disciples of Walton, presided over by Mr. William Senior, the angling editor of The Field. It was resolved that, as there was no memorial of Walton in London, funds should be raised to put a stained-glass window in St. Dunstan's, Fleet Street, with which church he was

birth and death had memorials of him, London, where he lived so long, where his children were born, and his Angler and other works published, had none. I added that I had written to the Rector of St. Dunstan's, Fleet Street, the Rev. William Martin, making the suggestion, and expressing the hope that he would approve of it. I have just received Mr. Martin's reply :-

“St. Dunstan's Vestry, Fleet Street, E.C.

"June I2th, 1893.

"My deAR Mr. Marston,-I cordially approve of your suggestion, and I am very grateful to you for writing to me about it.

"I should consider it a great honour to St. Dunstan's Church to have some memorial in it of Izaak Walton. I had better see you about it when it is convenient to you. "Very sincerely yours, "William Martin.

"R. B. Marston, Esq." 
so long connected, and where so many of those near and dear to him were buried. The vicar, the Rev. IV. Martin, tells me that the cost of the window will only be about $£$ Ioo, and I confidently hope we shall not only obtain this, but also a handsome surplus for the funds of the Anglers' Benevolent Society.

During UValton's residence in Chancery Lane, he experienced severe afflictions by the loss of no less than seven children, besides his wife and her mother. IValton's first wife, Rachel Floud, died on August 25th, r640. About six years later he married again, his second wife being Anne, daughter of Thomas Ken, an attorney in the Court of Common Pleas.

By his first marriage Walton became connected with the Cranmer family, his wife,-Rachel Floud, being a daughter of Susannah, daughter of Thomas Cranmer, of Canterbury, son of Edmund Cranmer, Archdeacon of Canterbury, and a grand nephew of the great archbishop.

By his second marriage he became connected with a family "united by alliance with several noble houses" : his wife was the half-sister of Thomas Ken, afterwards the deprived Bishop of Bath and Wells. Walton was fifty-three at the time of his second marriage, his wife being 
about five-and-thirty; he himself tells us, in the inscription on her monument in Worcester Cathedral, that she was "a woman of remarkable prudence, and of the primitive piety; her great and general knowledge being adorn'd with such true humility, and blessed with soe much Christian meeknesse as made her worthy of a more memorable monument." It is certain, from these lines and others addressed to her by Walton, that their married life of sixteen years was a very happy one. The first child of this marriage was) a daughter, Anne, born March i Ith, 1648. In $165^{\circ}$ a son was born, but only lived a few months, making the eighth child Walton lost by death. In I65 I, on September 7 th, another son was born, the note of his birth being thus entered by Walton in the family Prayer Book :-

"My last son Isaac, born the 7 th of September, $165^{\mathrm{x}}$, at half an hour after two o'clock in the afternoon, being Sunday, and so was baptized in the evening by Mr. Thornton in my house in Clerkenwell. Mr. Henry Davison and Brother Beauchamp were his God-fathers, and Mrs. Row his God-mother."

From 1650 to $x 661$ Walton appears to have resided at Clerkenwell. It was during his residence here that the first 


\section{The Collar of}

edition of The Compleat Angler (1653) was published.

It was also during this period that occurred the incident of his being instrumental in preserving the lesser George which belonged to Charles II., as related by Ashmole in his history of the Order of the Garter.

Soon after the battle of Worcester, September 3rd, 165I, when Cromwell defeated the King with a loss of six thousand men and all their baggage, a collar of $*$ and a garter which belonged to his majesty, formed part of the spoil, and were brought to Parliament a few days afterwards by Major Corbet, who was despatched by Cromwell with an account of his victory. The sovereign's lesser George was, however, preserved by Colonel Blague, who, having taken shelter at Blore, Pipe House, two miles from Eccleshall, in Staffordshire, then the residence of Mr. George Barlow, delivered the jewel into that gentleman's custody. In the ensuing week Mr. Barlow carried it to

* In his charming little work Hic et Ubique, Sir William Fraser has this note: "Endless disputes have been held in relation to the collar

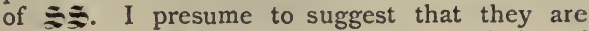
intended to indicate the word 'sanctissimus,' abbreviated." 
Robert Milward, Esq., who was at that time a prisoner in the garrison of Stafford, and Milward shortly afterwards gave it into "the trusty hands" of Mr. Izaak Walton, to convey to Colonel Blague, who was confined by the Parliament in the Tower of London. It is said that Colonel Blague, "considering it had already passed so many dangers, was persuaded it could yet secure one hazardous attempt of his own "; and having made his escape from the Tower, he had the gratification of restoring the George to the King.

Ashmole relates this interesting anecdote from the statements of Blague, Milward, and Walton, and speaks of the latter as " $\mathrm{a}$ man well known, and as well beloved of all good men, and will be better known to posterity by his ingenious pen in the Lives of Dr. Donne, Sir Henry Wotton, Mr. Richard Hooker, and Mr. George Herbert."

That the service Walton thus performed for his King was one of great peril there can be no doubt: he had to communicate between two Royalist prisoners, through a country full of Cromwell's rough soldiery and adherents; he carried what might have cost him his life, had it been discovered in his possession; for had not 
Parliament proclaimed "that whoever shall assist the King with Horse, Arms, Plate or Money against them, are Traytors to the Parliament "? - and they had a short, sharp way of dealing with "Traytors."

Between $165 \mathrm{I}$ and $\mathrm{r} 66 \mathrm{I}$ almost the only particulars we have of Walton are from scattered references in his works. He lost his second wife, Anne, in I662, and in December of that year he obtained from his friend Gilbert Sheldon, Bishop of London, a lease of a newly erected building, adjoining a house called the Cross Keys, in Paternoster Row, for forty years, at the yearly rent of forty shillings, which premises were burnt in the Great Fire of London.

"After the Restoration" (I660), says Dr. Zouch, "Walton and his daughter had apartments constantly reserved for them in the houses of Dr. Morley, Bishop of Winchester, and Dr. WVard, Bishop of Salisbury."

The charming letter from Walton to Cotton which is prefixed to the first edition of Cotton's Part II. of The Compleat Angler is dated "London, 1676." I have just copied it from a little timeworn edition of that date now in my possession, which is bound up in the original old calf binding with the fifth 
edition of Walton and Colonel Venables' Experienc'd Angler. I must refer more fully to this little volume presently.

Walton died at Winchester on December 15 th, I683, during the memorable frost of that year, at the Prebendal House of his son-in-law, Dr. Hawkins, whom, as he says in his will, he loved as his own son. He was buried in Winchester Cathedral, in Prior Silkstead's Chapel ; a large black marble slab in the floor of the chapel marks his resting-place. "The morning sun falls directly on it, reminding the contemplative man of the mornings when he was for so many years up and abroad with his angle."

It was my good fortune to be able to accomplish, by the assistance of the readers of The Fishing Gazette, what had for nearly a century been the wish of admirers of Walton-viz., that a statue of him should be erected to his memory in Winchester Cathedral. The Very Rev. Dr. Kitchin, Dean of Winchester, gave us the kindest assistance, reserving a niche in the beautiful great screen in the cathedral for the statue, which was very ably executed by Miss Mary Grant. 


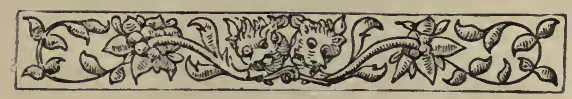

\section{CHAPTER VIII.}

The First Editions of The Compleat AnglerEffect on My Library of the Abnormally Early May-Fly Season of this Year (1893)Curious Printer's Error in the Copies First Printed of the Angler-Walton's First TitlePage-His "Epistles Dedicatory" and "Addresses to the Reader"-Some Past and Present Money-Values, of a First Edition.

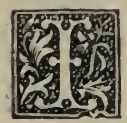

HAVE before me an original copy of the First EDITION of Walton's book in a very perfect state of preservation. I have borrowed it from the "Amateur Angler," who, writing in The Fishing Gazette on May I 2 th, I888, says, in an article called "An Outing with Izaak Walton on a Fine May Morning"*:-

"I am the happy possessor of a perfect copy of the first edition of The Compleat Angler. The title runs thus: The Compleat Angler, or the Contemplative Man's Recreation.

* Since reprinted with other articles under the title of Days in Clover." 


\section{First Eilition of the "Angler."}

"The above portion of the title-page is beautifully engraved on a scroll, with a pair of dolphins above and a pair below, and a bunch of fish pendent from the tails of the upper ones on either side of the scroll. Then follows in plain type: 'Being a discourse of Fish and Fishing, not unworthy the perusal of most anglers. [And between two rules] Simon Peter said, "I go a-fishing"; and they said, "We also will go with thee."-John xxi. 3 . (London: Printed by T. Maxey, for Rich. Marriot, in St. Dunstan's Churchyard, Fleet-street, I653.)'

"Izaak Walton's name does not appear on this title-page ; but in an advertisement of it in The Perfect Diurnal, it is said to be 'Of eighteen-pence price. Written by Iz. Wa.' It was published in the beginning of the month of May."

- But this copy, although of the first edition, is not one of the first copies printed of that edition, as those contained a printer's error, which, when Walton discovered it, doubtless made him put on his hat, and go with all speed to his friend and publisher Richard Marriot to stop the press.

Since writing these lines I have had a rare hunt all over my library to find a copy of a reprint of the first edition 
containing the error. The May-fly came up all out of time this year. I had to hurry off to Hampshire almost three weeks earlier than usual. On my return I found that a terrible thing had happened; and yet I was expected to say, and did say, it was delightful. My library had been "dusted and put straight." Goodness knows it required it badly enough! Still, I groaned inwardly as my eyes wandered in search of the old familiar landmarks.

It was as if an earthquake had taken place, and the face of the country was all altered. A few weeks ago I knew that this particular edition of Walton was in the latitude of White's Selborne and the longitude of Landor's Imaginary Conversations; but Landor I find has been promoted, and White I have not yet found. Books which for years have been in the Northern Hemisphere are now new islands in the South Pacific. I feel like a sailor without compass or chart. Even great continents have been split up. Fourteen volumes of The Literature of the 1883 Fisheries Exhibition until recently stood shoulder to shoulder; now five of them are missing-lost for the present in the multitude. In this hot weather it gives one a feeling of hopelessness. I want one book. I must look over perhaps. 
a thousand before I find it. Still, it is true there are compensations. Valued old friends, given up for years as lost or lent (synonymous words when books are concerned), suddenly meet the eye. Senior's Travel and Trout at the Antipodes, which I had often looked for in vain, is in the very spot where Henshall's Book of the Black Bass used to be. At any rate I have, as our American friends say, "located" one book. Senior is where Henshall was. I hope Henshall is not where Senior wasbehind and out of sight-or he won't reappear until the next earthquake.

I had, during many years, gradually gathered together various editions of Walton's Angler, of his Lives, works by friends of Walton, or contemporary or subsequent writers who refer to him. These were of all sorts and sizes, but all together; now they are scattered to the four corners of my library.

But if I have not found that reprint of Walton with the error in it, I have found a very pretty reprint by Mr. Elliot Stock, published in 1877 , also now out of print ; but it has the correction.

In the first copies of the Angler struck off for Richard Marriot there are some verses near the end, which are thus referred to by Walton. 
The Error in the First Edition. I 25

Piscator, after listening to Viator's recitation of Sir Henry Wotton's verses in praise of angling, says :-

"Trust me, Schcler, I thank you heartily for these verses ; they be choicely good and doubtless made by a lover of angling. Come, now drink a glass to me and I will requite you with a very good copy of Verses; it is a farewel to the vanities of the world, and some say written by Dr. D.; but let them be writ by whom they will, he that writ them had a brave soul, and must needs be possest with happy thoughts at the time of their composure."

The last two lines of the verses run:-

"And if contentment be a stranger, then I'l nere look for it, but in heaven again."

But in the first copies these lines were thus printed:-

"And if contention be a stranger, then I'l nere look for it, but in heaven again."

As pointed out by Sir Harris Nicolas and by Mr. Westwood in his admirable Chronicle of "The Compleat Angler," there are several other misprints in these first copies, such as "Fordig " for "Fordidg," "Padoch " for " Padock," etc. For a very minute account of the differences and additions in the five editions published 
during Walton's lifetime, I must refer the reader to Mr. Westwood's Chronicle.*

Of all the scores of title-pages of editions of Walton's Angler none excels the first, reproduced on the opposite page.

The Dedication.

In his dedication to the Right Worshipful John Offley, of Madely Manor, in the County of Stafford, Esq., Walton says :-

"My Most Honoured Friend,-

"SIR,-I have made so ill use of your former faviors as by them to be encouraged to intreat that they may be enlarged to the patronage and protection of this Book; and I have put on a modest confidence that I shall not be denyed, because 'tis a discourse of Fish and Fishing, which you both know so well, and love and practice so much.

"You are assur'd (though there be ignorant men of another belief) that Angling is an Art; and you know that Art better then any that I know : and that this is truth, is demōstrated by the fruits of that pleasant labor which you enjoy when you purpose to give rest to your mind, and devest your self of your more

* A small "remainder" of this work was purchased by Sampson Low, Marston, \& Co., Ld. 
serious business, and (which is often) dedicate a day or two to this Recreation.

"At which time, if common Anglers. should attend you, and be eye-witnesses of your success, not of your fortune, but your skill, it would doubtless beget in them an emulation to be like you, and that emulation might beget an industrious diligence to be so : but $\mathrm{I}$ know it is not atainable by common capacities.

"Sir, this pleasant curiositie of Fish and Fishing (of $\mathrm{w}^{\mathrm{ch}}$ you are so great a Master) has been thought worthy the pens and practices of divers in other Nations, which have been reputed men of great Learning and Wisdome ; and amongst those of this Nation, I remember Sir Henry Wotton (a dear lover of this Art) has told me, that his intentions were to write a discourse of the Art, and in the praise of Angling, and doubtless he had done so, if death had not prevented him ; the remembrance of which hath often made me sorry; for, if he had lived to do it, then the unlearned Angler (of which I am one) had seen some Treatise of this Art worthy his perusal, which (though some have undertaken it) I could never yet see in English.

"But mine may be thought as weak and as unworthy of common view : and I do here freely confess, that I should 
rather excuse myself, then censure others, my own Discourse being liable to so many exceptions ; against which, you (Sir) might make this one, That it can contribute nothing to your knowledge; and lest a longer Epistle may diminish your pleasure, I shall not adventure to make this Epistle longer then to add this following truth,

"That I am really, Sir,

"Your most affectionate Friend, " and most humble Servant "Iz. WA."

In his "Epistles Dedicatory" and " Addresses to the Reader" Walton excels. There is such a pleasant, modest style and gentle humour about them, that the reader feels at once he is introduced to the company of no ordinary writer. It will be noticed that in the closing lines of the dedication just quoted there is an unnecessary repetition of the word "Epistle." On turning to his fifth edition-the last and most complete of those published in his lifetime-I find that he noticed this, altering the lines to-

" and lest a longer Epistle may diminish your pleasure, I shall make this no longer than to add," etc. He also altered "favor" to "favovr" "then" to "than" "demõstrated" to "demonstrated" etc. 
$₫ 30$ The Address to the Reader.

The Address to the ReAder.

This gives such a clear idea of the nature and object of his work that I shall quote it, giving the version finally revised by him, as it contains all that is in the first edition with some interesting additions.

"To all Readers of this Discourse, but ESPECIAlly to the Honest ANGLER.

"I think fit to tell thee these following truths, That I did neither undertake, nor write, nor publish, and much less own, this Discourse to please my self : and having been too easily drawn to do all to please others, as I propos'd not the gaining of credit by this undertaking, so I would not willingly lose any part of that to which I had a just title before I begun it, and therefore do desire and hope, if I deserve not commendations, yet, I may obtain pardon.

"And though this Discourse may be liable to some exceptions, yet I cannot but doubt but that most Readers may receive so much pleasure or profit by it, as may make it worthy the time of their perusal, if they be not too grave or too busie men. And this is all the confidence 
The Address to the Reader. I 3 I

that I can put on concerning the merit of what is here offered to their consideration and censure; and if the last prove too severe, as I have a liberty, so I am resolv'd to use it and neglect all sowre Censures.

"And I wish the Reader also to take notice, that in writing of it I have made my self a recreation of a recreation; and that it might prove so to him, and not read dull and tediously I have in several places mixt (not any scurrility, but) some innocent harmless mirth ; of which, if thou be a severe, sowre-complexioned man, then I here disallow thee to be a competent judge ; for Divines say, There are offences given, and offences not given but taken.

"And I am the willinger to justifie the pleasant part of it, because though it is known I can be serious at seasonable times, yet the zollole discourse is, or rather was, a picture of my ozen disposition, especially in such days and times as I have laid aside business, and gone a fishing with honest Nat. and R. Roe; but they are gone, and with them most of my pleasant hours, even as a shadow, that passeth away, and returns not.

"And next let me add this, that he that likes not the book, should like the excellent picture of the Trout, and some 
132 The Address to the Reader.

of the other fish; which I may take a liberty to commend, because they concern not myself.

"Next let me tell the Reader, that in that which is the more useful part of this Discourse, that is to say, the observations of the nature and breeding, and seasons, and catching of Fish, I am not so simple as not to know, that a captious Reader may find exceptions against something said of some of these; and therefore I must entreat him to consider, that experience teaches us to know, that several Countries alter the time, and I think almost the manner, of fishes breeding, but doubtless of their being in season; as may appear by three Rivers in Monmouthshire, namely Severn, Wie, and Usk, where Cambden (Brit. f. 633)* observes, that in the River IVie, Salmon are in season from Sept. to April, and we are certain, that in Thames and Trent, and in most other Rivers they be in season the six hotter months. $\uparrow$

"Now for the Art of catching fish, that is to say, how to make a man that was

* The editor of one edition of Walton turns (Brit. f. 633) into (British Fishes, 633).

$\dagger$ If Walton had known the Wye as he did the Thames and Trent, he would have corrected the cclebrated author of the Britannia. 
none, to be an angler by a book? he that undertakes it shall undertake a harder task than Mr. Hales (a most valiant and excellent Fencer), who in a printed book (called, A private School of Defence) undertook to teach the art or science, and was laugh'd at for his labour. Not but that many useful things might be learnt by that book, but he was laugh'd at, because that art was not to be taught by words, but practice : and so must Angling. And note also, that in this Discourse I do not undertake to say all that is known, or may be said of it, but I undertake to acquaint the Reader with many things that are not usually known to every Angler; and I shall leave gleanings and observations enough to be made out of the experience of all that love and practice this recreation, to which I shall encourage them. For Angling may be said to be so much like the Mathematicks, that it can ne'er be fully learnt; at least not so fully, but that there will still be more new experiments left for the tryal of other men that succeed us.

"But I think that all that love this game may here learn something that may be worth their money, if they be not poor and needy men; and in case they be I then wish them to forbear to buy it; for 


\section{34 The Address to the Reader.}

I write not to get money, but for pleasure, and this Discourse boasts of no more; for I hate to promise much and deceive the Reader.

"And however it proves to him, yet I am sure $I$ have found a high content in the search and conference of what is here offer'd to the Reader's view and censure : I wish him as much in the perusal of it, and so I might here take my leave, but will stay a little and tell him, that whereas it is said by many, that in Flye-fishing for a Trout, the Angler must observe his 12 several flies for the twelve months of the year; I say, he that follows that rule, shall be as sure to catch fish, and, be as wise, as he that makes Hay by the fair days in an Almanack, and no surer; for those very flies that use to appear about and on the water in one month of the year, may the following year come almost a month sooner or later ; as the same year proves colder or hotter; and yet in the following Discourse I have set down the twelve flies that are in reputation with many Anglers, and they may serve to give him some observations concerning them. And he may note that there are in Wales and other countries, peculiar flies, proper to the particular place or country; and doubtless unless a man makes a flie to 
counterfeit that very flie in that place, he is like to lose his labour or much of it: But for the generality, three or four flies neat and rightly made, and not too big, serve for a Trout in most Rivers all the Summer. And for Winter flie-fishing it is as useful as an Almanack out of date: And of these (because as no man is born an artist, so no man is born an Angler) I thought fit to give thee this notice.

"When I have told the Reader, that in this fifth Impression there are many enlargements, gathered both by my own observation, and the communication with friends, I shall stay him no longer than to wish him a rainy evening to read this following Discourse; and that (if he be an honest Angler) the East wind may never blow when he goes a Fishing.

"I. W."

Let me refer the reader again to the lines which I have printed in italics in this copy of Walton's address to the reader. He tells us there that it is, "or rather was a picture of my own disposition." There is a touch of sadness in the "or rather was." Walton was over eighty when he wrote thus. His fishing companions, "honest Nat. and R. Roe," referred to in his first edition, are, he tells 


\section{I36 Why Walton is Loved.}

us, dead. But if we had nothing but the book itself to tell us what he was, we should read his character aright. His genial, broad-minded, generous, honest spirit is stamped on every page. We shall see presently in what estimation he was held by some of the best men of his own day and since. His book is aglow with human interest, and in this lies its everfresh, ever-enduring power to charm; he clothed the dry bones of a practical treatise on fishing with so attractive a garb of joyous love of nature and human nature, that he must indeed be a "severe sowre-complexioned" man who cannot love him.

In the "Amateur Angler's" copy of the first edition is fastened a little manuscript in faded ink, evidently written by some admirer of Walton many years ago : the only clue to the writer are the initials W. E. I give some extracts from it :-

"In Longman's Catalogue for 1816.

"No. 5435, Walton's Angler, first edition, London, I653, £4 4s.

"No. 5436, Walton's Angler, enlarged by Cotton, with Venables' Expericnc'd Angler, Russia, 1676, £3."

Then follows an account of the first five editions taken from one of the editions of Walton edited by Sir John Hawkins, 
who, as I have at some length noticed in my edition of Walton, was indebted to Oldys for most of the information given in the Lives of both Walton and Cotton.

From this extract we find that the market value of a copy of the first edition of Walton was about $f_{4} 4 s$. in 1816 . What is the value of it now? From a catalogue sent to me recently by Messrs. Pickering \& Chatto, 66, Haymarket, London, containing an advertisement of a first edition of Walton, I quote the following :-

"We here offer a PERfEct COPY of this precious little gem, for every page is genuine, and there is not so much as a page in facsimile. The last perfect copy brought by auction $£ 310$, and the present one we consider to be reasonably priced. The above is the first issue of first edition, and contains the misprint on page 245 , 'contention' for 'contentment."'

"Fair first editions, duly prized, Above them all, methinks, I rate The tome where Walton's hand revised His wonderful receipts for bait."

ANDREW LANG.

The price asked was $£ 235$. All good "Waltons" go to America. Messrs. Pickering \& Chatto have since informed me they sold this fine copy to an American collector. 


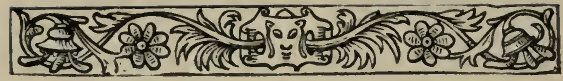

\section{CHAPTER IX.}

The Second Edition of The Compleat AnglerThe Illustrations-An Interesting Discovery - The Third and Fourth Editions-The more Important Fifth, with Cotton's Addition -Venables' Experienc'd Angler, Published with the Fifth Edition-Walton's Letter to Venables, and some Account of the LatterCharles Cotton's "Instructions How to Angle for a Trout or Grayling in a Clear Stream"Some Account of Cotton-His Friendship with Walton - His Family Affairs and Death.

The Second Edition of "The ComPLEAT ANGLER."

HIS was published by Richard Marriot in 1655 . I have only seen one or two copies of it in twenty-five years; and as $\mathrm{Mr}$. Westwood, quoting Mr. Bindley, the eminent book-collector, points out, it is even rarer than the first edition, although it does not command the same high priceBy the way, what will a first edition be ${ }_{13} 8$ 
worth, say, in 1993? Mr. Westwood, in 1883 , puts the value of a fine perfect copy at "from $£ 70$ to $£ 80$, or even more." Now (1893), as we have just seen, the price asked is $£^{2} 35$, and as much as $£ 3$ ro has been paid.

In the description of the second edition, Mr. Westwood, in his Chronicle of "The Compleat Angler," says: "The success of Walton's first essay in angling literature seems to have stimulated him to increased effort in preparing the second for the press. The work was, in fact, all but rewritten; more than one-third was added to its original bulk, and many improvements were introduced into it. The interlocutors are three in this edition: Piscator, Venator (who takes the place of Viatorwe are sorry to lose Viator), and Auceps. The chapters are twenty-one in number, the type, however, being larger than in the previous edition."

Respecting the

ILluStRations in WALTON'S Book,

Mr. Westwood says: "The first edition contains engravings of the trout, pike, carp, tench, perch, and barbel (to the second are added plates of the bream, eel, loach, and bullhead). The engraver is 
unknown; but Pierre Lombart, a noted Frenchman then resident in this country, and engaged in illustrating books, and also Faithorne and Vaughan, are possible candidates for the honour. We know that the last mentioned was employed by Marriot on other work. These plates, which are said, with little probability, to have been of silver, served for the first four editions, and were re-engraved in reverse, by a less artistic hand, for the fifth edition, a circumstance which has escaped notice."

I see that Sir John Hawkins, in his fourth edition of the Angler, has this note about the illustrations :-

"Walton, in the year 1653 , published, in a very elegant manner, his Compleat Angler, or Contemplative Man's Recreation, in small duodecimo, adorned with exquisite cuts of most of the fish mentioned in it. The artist who engraved them has been so modest as to conceal his name; but there is great reason to suppose they are the work of Lombart, who is mentioned in the Sculptura of Mr. Evelyn; and also that the plates were of steel."

Mr. Westwood, usually so extremely careful, had evidently overlooked this later account of Walton's book by Hawkins, 
or he would not have said that Hawkins "fixes the date of the first edition at about I660." As noted above, Hawkins gives the correct date, $\mathbf{1} 653$.

WHAT WERE THE ILLUSTRATIONS IN WALTON COPIED FROM? AN INTERESTING DisCOVERY.

Until this evening, when writing these lines, I had often wondered what the artist who engraved the fish in Walton's book copied them from. Had he the fish themselves, or did he copy some existing illustrations? Knowing that Walton frequently refers to the celebrated German naturalist Gesner, I took down from the shelf a copy of Dr. Conrad Forer's Auszfurliche beschreibung und lebendige Conterfactur aller und jeden Fischen, von dem kleinsten Fischlein an bisz auff den grösten Wallfisch, being the second part of a magnificent folio volume of over one thousand pages full of illustrations of animals, birds, reptiles, fishes, etc. It is a revised and enlarged German translation of Doctor Conrad Gesner's work Latein erstmals beschrieben, and was printed at Frankfort by Johann Saur, and published by Robert Cambier's Heirs in the year 1598. In this volume I found the 
originals of the illustrations in Walton's Angler. I do not say they were copied from this particular edition of Gesner, which, by the way, is not, as far as I can trace, included in the Bibliotheca Piscatoria. For beauty of typography and excellence of illustration I know few works on fish which can compare with this. The artist must have had the living or dead subject before him-except in the case of seaserpents, mermaids and men, devil-fish, and other mythical beasts and fishes, when he draws from the imaginations of travellers splendidly.

Compare the illustrations of the loach and bullhead in Walton, used also in Venables' Experienc'd Angler, with those in the 1598 edition of Forer's Fishes, also the carp, bream, tench, and perch. The trout and pike have not quite such a strong resemblance, but of the rest I think there can be no question. Walton continually refers to Gesner's great work; he evidently possessed a copy, and doubtless, when discussing the publication of the first edition of his work with Richard Marriot, they arranged to have reduced copies of the Gesner illustrations engraved. The illustrations added to the second edition are evidenily also taken from Gesner. 
The Eels and the Haystack. I43

The Eels and Great Frost of il 25.

By the way, I notice that Walton, in giving the story of the eels which died in the very cold winter of II25, says that " they did by nature's instinct get out of the water into a stack of hay in a meadow upon drie ground, and there bedded themselves, but yet at last a frost kill'd them." I find that Dr. Forer's Gesner gives the reason of the eels leaving the water as "aus hassung der Kälte" ("from hatred of the cold "), and the cause of their death in the haystack as "wegen der Kälte und mangel desz Wassers" ("on account of the cold and want of water").

The Third and Fourth Editions of "The Compleat Angler."

"The third edition," says The Chronicle of "The Compleat Angler," "was issued in I66I; but before many copies had been sold, and for some reason (not now discoverable, though possibly pecuniary), the sale of the book was transferred from Richard Marriot to Simon Gape ('near the Inner Temple Gate in Fleet Street '), by whom the remainder of the impression was sent forth, with a fresh title-page, dated I664." A few minor additions 
and corrections were made in this edition, and the chapter on the Laws of Angling "appears for the first time."

The fourth edition was published in r668, and " is a mere paginary reprint of the second, with the exception of the 'errata,' which are corrected in the work." This edition was "Printed for R. Marriot, and sold by Charles Harper, at his shop, the next door to the Crown near SergeantsInn in Chancery Lane."

\section{The Fifth Edition of Walton} AND THE FiRst OF CotTon.

The last edition of his work published during Walton's lifetime was the fifth, published in 1676 . I have a copy of the fat little volume, 6 in. by 4 , in its original binding, in which Walton's work is bound up with those of Venables and Cotton. In many respects this is the most interesting of all the editions. It was the last Walton had to do with, and the first which contained his friend Charles Cotton's "Instructions How to Angle for a Trout or Grayling in a Clear Stream," written with Walton's sanction as an addition to his work. It also contains a most characteristic letter from Walton to Venables, whom he thus addresses. 


\section{Walton's Letter to Colonel VENABLES.}

To His Ingenious Friend the Author on his "Angling Improv'd."

"Honoured Sir,-Though I never (to my knowledg) had the happiness to see your Face, yet accidentally coming to a view of this Discourse before it went to the Press, I held myself obliged in point of gratitude for the great advantage I received thereby, to tender you my particular acknowledgment, especially having been for thirty years past, not only a Lover but a practiser of that innocent Recreation, wherein by your judicious Precepts I find my self fitted for a Higher Form; which expression I take the boldness to use because I have read and practised by many Books of this kind, formerly made publick; from which (although I received much advantage in the practick) yet (without prejudice to their worthy authors) I could never find in them that height of Judgment and Reason, which you have manifested in this (as I may call it) Epitome of ANGLing since my reading whereof, I cannot look upon some Notes of my own gathering, but methinks I do puerilia tractare. But 
lest I should be thought to go about to magnifie my own Judgment, in giving yours so small a portion of its due, I humbly take leave with no more ambition than to kiss your hand, and to be accounted

Your humble and

thankful Servant, "I. WV."

\section{Colonel Robert Venables.}

The first edition of The Experienc'd Angler, by Venables, was published by Richard Marriot in I662. The best modern reprint is that published in $\mathrm{I} 827$ by $\mathrm{T}$. Gosden; it contains a memoir of the author, Colonel Robert Venables, from which it appears that he served in the Parliamentary army. In $\mathrm{I} 644$ he was made Governor of Chester; in 1649 he was Commander-in-Chief of the Forces in Ulster. In I654 Cromwell fitted out a fleet for the conquest of Hispaniola, and Colonel Venables and Admiral Penn were entrusted with the command. Gosden gives a long and interesting account of this unfortunate expedition, taken, he tells us, from a contemporary manuscript in his possession, which had not previously been printed. 
According to the writer, who was evidently no admirer of Cromwell, one of the objects of the expedition was to get Venables out of the way. "Twas doubtless," he says, "none of the least ends which that fox, Oliver, had in that design; to rid himself of some persons whom he could neither securely employ, nor safely discard: which end seemed chiefly to influence the managery of the whole business, as you will perceive by the story."

During this expedition Venables appears to have acted with the greatest bravery and fortitude in the face of a series of most trying disasters. On one occasion, at the assault of a fort, "he being before brought very low with his flux, the toil of the day had so far spent him, that he could not stand or go but as supported by two; and in that manner he moved from place to place, to encourage the men. But the latter he could not prevail on, neither by commands, entreaties, or offer of rewards. At last, fainting among them, he was carried off."

On their return to England in September, Venables and Penn were both imprisoned in the Tower. What became of Venables afterwards? Gosden, writing in 1827 , says: "His subsequent liberation, and 
the particulars of his life after this period, have baffled all attempts at discovery." It seems extraordinary that of a soldier so well known as Venables no trace can be found after his imprisonment in the Tower.

All we know about him after 1655 is that his book was published in 1662 , and that Walton wrote the charming commendatory letter to him which I have already quoted. Although a great deal of his writing is evidently the result of actual experience as an angler, I think it is equally clear that he used the prose version of The Secrets of Angling as a basis for his work. Among the rivers and places he mentions as having experience of are "the Weever in Cheshire, the Sow in Staffordshire, the Blackwater in Ulster, Lough Neaugh, Tom Shanes Castle, Mountjoy, Antrim," etc. $\mathrm{He}$ has some brief but interesting references to salmon and salmon-fishing, and evidently, when stationed in different parts of England and Ireland, occupied his leisure time in angling. Want of space prevents a longer notice of the work of this brave soldier, devout man, and keen angler, whom Walton tells us he never had the happiness to meet face to face. 


\section{Charles Cotton and His Part of "The Compleat ANgler."}

It was not until the fifth edition of Walton's book appeared that his friend Cotton's "Instructions How to Angle for a Trout or Grayling in a Clear Stream" were added to it.

Charles Cotton, Oldys tells us, was descended of a worthy and honourable family, and was the grandson of Sir George Cotton, Knight, who died in $16 \mathbf{1}_{3}$, leaving issue by Cassandra MacIVilliam, his wife, two children, Charles and Cassandra. The latter died unmarried before $\mathbf{I} 649$. Charles Cotton, the father of the author of the second part of The Compleat Angler, lived at one time at Ovingden, or Ovingdean, in the county of Sussex. He married Olive, the daughter of Sir John Stanhope, of Elvaston, in Derbyshire, by his first wife, Olive, daughter and heiress of Edward Beresford, of Beresford and Enson, in Staffordshire, and of Bentley, in the county of Derby. He succeeded to those estates in her right, and settled at Beresford. This lady, Olive Stanhope, died in 1614 , aged about thirty-three years; and Drayton, the poet, among his elegies, has one in her commendation. Her daughter, named likewise Olive, 
I 50 Life of Charles Cotton.

heiress to her mother, left, by her husband, Charles, before mentioned, one son, named also Charles Cotton, of Beresford, Esq., the subject of this notice.

Cotton's father's marriage connected him with the families of Stanhope, Cockayne Aston, Port, and others of the highest rank in the counties of Derby and Stafford. He was distinguished for his talents and accomplishments, and was the friend and companion of many of the most eminent of his contemporaries, including Fletcher, Herrick, Carew, Ben Jonson, Sir Henry Wotton, Dr. Donne, Selden, Lovelace, Davenant, May, Lord Chief Justice Vaughan, and the great Lord Clarendon, who describes him as having "all those qualities which in youth raise men to the reputation of being fine gentlemen; such a pleasantness and gaiety of humour, such a sweetness and gentleness of nature, and such a civility and delightfulness in conversation, that no man, in the Court or out of it, appeared a more accomplished person; all these extraordinary qualifications being supported by as extraordinary a clearness of courage and fearlessness of spirit, of which he gave too often manifestation."

Charles Cotton, son of the man thus described by Clarendon, was born on 


\section{Life of Charles Cotton. I5I}

April 28th, I630. His father was at Cambridge University, and it is probable he was also ; but there is no direct evidence on this point.

"Besides his academic or classical learning, he was happy in a graceful address, and well versed in the modern languages. $\mathrm{He}$ was ardently attached to literature; but, except a few poems, he wrote nothing which was published till after the Restoration. He probably went abroad when a young man, and he himself mentions his having been in France and other foreign countries. It is evident, says Oldys, that after he came to be settled at home, he was early in much esteem, and conversant with many persons of high rank and repute, more especially with his cousin, Sir Aston Cockayne, Bart., of Pooley, in Warwickshire, and Ashbourne, in the Peak, who was well known to the noted poets and wits of his time; also with Thomas Flatman, Esq., barrister of the Inner Temple, Alexander Broome, Izaak Walton, and others."

I venture to think that the portrait of Charles Cotton which forms the frontispiece to vol. ii. of my "Lea and Dove" edition of The Compleat Angler is much the best which has been published. This photo-etching is from an exquisite painting 


\section{Life of Charles Cotton.}

by Sir Peter Lely of Cotton when a young man of twenty-seven; it bears the date I657. Mrs. Evelyn Holden, of Nuttall Temple, Nottingham, most kindly gave me permission to have it photographed.

In $165^{8}$ Cotton's friend Lovelace, the poet, died "in a mean lodging in Gunpowder Alley, near Shoe Lane," and it is pleasant to read Aubrey's statement that "George Petty, haberdasher in Fleet Street, carried twenty shillings to him every Monday morning from Sir Many and Charles Cotton, Esq., for months, and was never repaid."

It is clear from his writings that Cotton, like Walton, was a staunch Royalist. Oldys says that, besides devoting himself to literature, he employed himself also in the delightful amusements of planting, gardening, and, above all, the sober recreation of angling, in which he became "by long practice and experience most eminently expert." It is to the fact that he loved angling and was acquainted with Izaak Walton that he owes most of his posthumous fame. One finds here and there humour, power, and a graceful fancy in his poems; but these qualities were possessed at least equally by many of his contemporaries, whose very names are 
almost forgotten, and whose writings are known only to the student.

Cotton appears to have asked Walton if he should supplement The Compleat Angler by some "particular directions" how to angle for a trout or grayling in a clear stream, to which Walton agreed. Nothing could be more modest than Cotton's letter accompanying his MS., or more kind and appreciative than Walton's reply; and although Cotton's work lacks much of that peculiar charm which, as Doctor Zouch says, will always endear IValton's book even to those who care nothing about angling, it cannot be denied that it is a very worthy addition to, and completion of, The Compleat Angler. Cotton was an accomplished angler in the highest branches of the art; his instructions are so clear and practical that it is quite certain he wrote from personal experience, and in this respect his work is more original than some of the practical parts of Walton's. Indeed, it may be said, that, while Walton is the father of general anglers, Cotton is the apostle of the trout and grayling fisherman, and many of his instructions have been but little improved upon, even to the present day. In one place he advises the use even in February, in case 
I 54 Cotton's Letter to Walton.

of a frost or snow, of "the smallest gnats, browns, and duns you can make."

That Cotton had but a poor opinion of London-made flies is clear from his reply to Viator, who had just told him that he likes a fly Cotton has made for him "admirably well, and it perfectly resembles a fly; but we about London, make the bodies of our flies both much bigger and longer, so long as almost to the very beard of the hook." "I know it very well," says Cotton, "and had one of those flies given me by an honest gentleman, who came with my father Walton to give me a visit; which, to tell you the truth, I hung in my parlour window to laugh at."

Cotton's Letter to Walton, Sent wiTh His MS.

"To my most Worthy Father and Friend, "Mr. IzaAK Walton, the Elder.

"Sir,-Being you were pleased some years past, to grant me your free leave to do what I have here attempted; and observing, you never retract any promise when made in favour even of your meanest friends; I accordingly expect to see these following particular Directions for the taking of a Trout, to wait upon your better and more 
general Rules for all sorts of Angling: And though mine be neither so perfect, so well digested, nor indeed so handsomely coucht as they might have been, in so long a time as since your leave was granted; yet I dare affirm them to be generally true: And they had appeared too in something a neater dress, but that I was surpriz'd with the suddain news of a suddain new edition of your Compleat Angler; so that, having but a little more than ten days time to turne me in, and nub up my memory (for in truth $I$ have not in all this long time, though I have often thought on't, and almost as often resolv'd to go presently about it), I was forc't upon the instant to scribble what I here present you: which I have also endeavour'd to accommodate to your own Method. And, if mine be clear enough for the honest Brothers of the Angle readily to understand: (which is the only thing $I$ aim at) then I have my end; and I shall need to make no further Apology; a writing of this kind not requiring (if I zereve Master of any such thing) any Eloquence to set it off, or recommend it; so that if you, in your better Judgment, or Kindness rather, can allow it passable for a thing of this nature; You will then do me honour if the Cypher fixt and carv'd in the front of my little fishinghouse may be here explained: And, permit 
me to attend you in publick, who in private have ever been, am, and ever resolve to be,

$$
\text { "Sir, }
$$

"Your most affectionate

"Son and Servant,

"Charles Cotton.

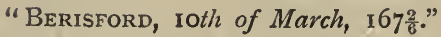

To this letter Walton replied as follows :-

\section{"To my most Honoured Friend "Charles Cotton, EsQ.}

"Sir,-You now see, I have return'd you, your very pleasant, and useful discourse of the Art of Flie-Fishing Printed, just as 'twas sent me : for I have been so obedient to your desires, as to endure all the praises you have ventur'd to fix upon me in it. And when $I$ have thankt you for them, as the effects of an undissembled love: then, let me tell you, Sir, that I will endeavour to live up to the character you have given of me, if there were no other reason; yet for this alone, that you, that love me so well, may not, for my sake, suffer by a mistake in your Judgment.

And, Sir, I have ventur'd to fill a part of your Margin, by way of Paraphrase, for the Readers clearer understanding the situation both of your Fishing-House, and the pleasantness that you dwell in. And 
I have ventur'd also to give him a Copy of Verses, that you were pleas'd to send me, now some Years past; in which he may see a good Picture of both; and, so much of your own mind to, as will make any Reader that is blest with a Generous Soul, to love you the better. I confess, that for doing this you may justly Judg me too bold : if you do, I will say so too: and so far commute my offence, that, though I be more than a hundred Miles from you, and in the eighty third year of my Age, yet I will forget both, and next month begin a Pilgrimage to beg your pardon, for, I would dye in your favour : and till then will live,

$$
\begin{aligned}
& \text { " "Sir, } \\
& \text { " Father and Friend, } \\
& \text { "IzAAK IVALTON. }
\end{aligned}
$$

"London, April 29th, 1676."

It will be noticed that Cotton, in his letter to Walton, says he has endeavoured to accommodate the method of his work to Walton's - that is to say, has put it into the form of "A Discourse" between "Piscator Junior" (himself) and "Viator." I think he succeeded admirably, his imaginary conversations being almost as natural, and quite as instructive as those 
I58 J. R. Lowell and Cotton.

between the characters in Walton, while he never loses an opportunity of speaking in warmest praise of his old friend. I must give a quotation or two from him, as showing the esteem and affection in which Walton was held by the handsome soldiercourtier, and man of the world, Charles Cotton.

James Russell Lowell wrote an "Introduction" to an edition of The Complete Angler published in $\mathrm{I}_{889}$ by Messrs. Little, Brown, \& Company, of Boston, U.S.A., and it is pleasant to find such a writer has no stone to throw at Cotton; for, indeed, editor after editor has almost erected a monument to him in this fashion. It is true that he, like Donne, wrote some verse, of which he, like Donne, was doubtless afterwards ashamed. As Lowell says : "Cotton was a man of genius, whose life was cleanlier than his muse always cared to be. If he wrote the Virgil Travesty, he also wrote verses which the difficult Wordsworth could praise, and a poem of gravely noble mood addressed to Walton on his Lives, in which he shows a knowledge of what goodness is that no bad man could have acquired. Let one line of it at least shine in my page, not as a sample, but for its own dear sake:-

'For in a virtuous act all good men share.'" 
Cotton's Opinion of Walton. I 59

I hope to refer again to Lowell's "Introduction" when noticing some of the later editions of the Angler.

After this kindly reference to him, I will give one or two quotations from his work, which surely were written with sincerity, and, being so, are themselves witnesses for the good in Cotton's character.

Cotton's Opinion of Walton.

"Viator. You go far, Sir, in the praise of your Country Rivers, and I perceive have read Mr. Walton's Compleat Angler by your naming of Hantshire, and I pray what is your opinion of that Book?

"Piscator Junr. My opinion of Mr Walton's Book is the same with every man's, that understands anything of the Art of Angling, that it is an excellent good one, and that the fore mentioned Gentleman understands as much of Fish, and Fishing, as any Man living: but I must tell you further, that I have the happiness to know his person, and to be intimately acquainted with him, and in him to know the worthiest Man, and to enjoy the best and the truest Friend any Man ever had : nay, I shall yet acquaint you further, that he gives me leave to call him Father, and I hope is not yet 
asham'd to own me for his adopted Son. ... My father Walton will be seen twice in no Man's company he does not like, and likes none but such as he believes to be very honest men, which is one of the best Arguments, or at least of the best Testimonies I have, that I either am, or that he thinks me one of those, seeing I have not yet found him weary of me.

"Viator. You speak like a true Friend, and in doing so render your self worthy of his friendship."

That the friendship between Walton and Cotton, which found so charming an expression in their letters and works, was continued to the last, is proved by the fact that, in Walton's will, dated August I6th, I683, among those named to receive a ring, with the motto "A friend's farewell, I. W., obiit," was "Mr. Chas. Cotton,"-a fitting end to one of the most delightful episodes in literary history.

Cotton's Family Affairs and Death.

Cotton was married about the year r656 to Isabella, daughter of Sir Thomas Hutchinson, of Owthorp, by whom he had three sons and five daughters. $\mathrm{He}$ was married a second time, his second wife being the widow of IVingfield Cromwell, 
Earl of Ardglass, by whom he had no children, and who survived him.

For many years before his death Cotton was often in great pecuniary difficulties. In answer to a letter of mine asking if possibly some unpublished papers relative to Charles Cotton existed, Mr. Philip Beresford Hope, the present owner of Beresford Dale, very kindly replied as follows :-

"Dear Sir,-Many thanks for your letter. I am afraid we have no unpublished papers relative to Charles Cotton. If it would be of any use to you, I could let you have some photographs and drawings of Beresford Hall in a partially ruined state, before it was pulled down. I do not know whether you are aware of a cave in the limestone rocks in Beresford Dale, well hidden from view, in which Charles Cotton is popularly reported to have hidden from his creditors for some weeks, and to have evaded them. I am also unaware if you are cognisant of the fact that the interior of Cotton's Fishing-House was at one time frescoed with paintings of piscatorial and other sporting subjects. I will, on my return to town, make a search for any unpublished matter relative to Charles Cotton, and if I come across 
any, I will communicate with you. I must thank you very much for the beautiful plate of Pike Pool you sent me. "Yours truly, (Signed) "P. Beresford Hope."

The plate Mr. Beresford Hope refers to is one of Pike Pool, by Mr. Geo. Bankart, which appears in the "Lea and Dove" edition of the Angler.

Cotton is supposed to have died of a fever on February 1 3 th, 1687, only four years after the death of his old friend Walton. By an act of administration of his effects upon his decease, dated September I2th, 1687, it appears his principal creditrix was Elizabeth Bludworth, and he is described as of the parish of St. James, Westminster. His son, Beresford Cotton, commanded a company in a regiment of foot raised by the Earl of Derby for the service of King William; one of his daughters married Dr. Geo. Stanhope, Dean of Canterbury. 


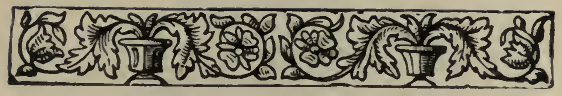

\section{CHAPTER $\mathrm{X}$.}

An Estimate of the Influence of Walton's Book on Angling and Angling Literature-It can Never be Antiquated-Has Kept the True Sporting Instinct Alive-Diversity of Baits Recommended by Walton-His Chapter on Trout-Fishing-The Celebrated Fordidge Trout-Walton and his Editors-What would He think of Some of our Modern Automatic Angling Appliances?-His Religion - His Reference to Hampshire StreamsNotes on other Chapters of His Book-A Tip for Dry-Fly Anglers-Did Walton Keep a Horse ?-His Directions for Bream, Barbel, and other Fishing-Fishing-Tackle Makers Mentioned by Walton-His Chapter on FishPonds-A Drink like Nectar.

"The Compleat Angler" from an ANGLER's Point of View.

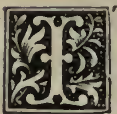

$T$ would be out of place to go fully into the practical value of Walton and Cotton's work in a little book of this kind, but a few general remarks may be admissible.

Compared with all that had preceded it, it can certainly be said not only to 163 
I64 An Estimate of the "Angler."

justify its title, but to have at once become the standard text-book of angling. That the anglers of Walton's day fully appreciated it is proved by the five editions published before he died; and since then the demand for it, especially during the last century, has been such that more than one hundred editions have been called for,not, of course, that all these editions have been produced to meet the wants of those who wish to learn the art of angling: its other, higher, and far more lasting merits are becoming more and more responsible for the continued demand for it. Since angling books have been produced in such numbers that the literature of the subject is more voluminous than that of almost any other, since the art has been so elaborated that volumes are devoted to one fish and the methods of its capture, it can no longer be said that The Compleat Angler is complete. But it is mainly responsible for this vast literature, this widespread love of a most delightful sport, which counts its votaries by hundreds of thousands scattered all over the world, and employs an enormous capital in supplying their wants.

But in spite of all our modern knowledge, I should still recommend those who would learn what angling is to go to the 
It can never be "Antiquated." 165

pages of the "tenderest teacher and powerfullest preacher" our art has ever had. What may be missing in science can be found elsewhere, and will be more than made up for by his description of what we may call the essence of the art, by the simple, often quaint, but always perfect expositions of the true spirit of angling which are given in his book as in none other.

I confess I cannot understand those anglers-and I have met some-who scoff at Walton as being antiquated. In mere practical details he may not always be equal to that scientific, mechanical precision in angling for which we have, in my humble opinion, far too much admiration in the present day; but as a teacher of all that part of angling which is most worthy our enthusiasm and love, Walton is not and never can be antiquated.

For instance, I open his book at random, and find a strong argument in favour of the keeping of fence months :-

"The not keeping of Fence months for the preservation of Fish will in time prove the destruction of all rivers. . . . He that shall view the wise statutes made in the 13 of Edw. the I. and the like in Rich. the III. may see several provisions made against the destruction of Fish : and though I 
profess no knowledge of the Law, yet I am sure the regulation of these defects might be easily mended. But I remember that a wise friend of mine did usually say, That which is every bodies business, is no bodies business. If it were otherwise, there could not be so many Nets and Fish that are under the statute size, sold daily amongst us, and of which the Conservators of the Waters should be ashamed.

"But above all, the taking Fish in spawning time, may be said to be against nature ; it is like taking the dam from her nest when she hatches her young."

It is a bold thing to say, but I doubt if these words of Walton had not been ringing down the centuries ever louder and louder, that our fresh-water fisheries would have long ago been destroyed. These and many similar passages in which unfair and unseasonable fishing is denounced have kept alive the true sporting instinct among anglers, and enabled them of late years, when by combination they became powerful, to obtain from our governments laws for the protection of their interests which as individuals they asked for in vain.

As regards many of the baits recommended by Walton, present-day anglers have, as a rule, no knowledge of them, and 


\section{Baits.}

much of the want of sport complained of, in such well-stocked and well-protected rivers as the Lea, Thames, and Trent, is due to the continual use of the same baits and ground-baits, and the overdosing the fish with the latter. The British angler treats the fish pretty much as his wife treats him: it is beef and mutton one week, and mutton and beef the next. Walton taught the use of a great variety of baits; and when worms, paste, and gentles failed, knew a dozen as good to try. Most of the wild fruits and berries are food for birds when ripe, and some kinds of fish take them also. I remember once, when fishing for large bream in a deep pool, being unable to obtain even a nibble with the three stock baits of to-day-gentles, worms, and paste ; but noticing some ripe blackberries overhanging the water, I determined to try them as bait, and very soon had two or three good fish, and often afterwards made good use of that and similar pleasant baits to which the fish had become accustomed, after a little trouble on my part in baiting a place or two. I think the sense of smell is very strong in some fish. Tench, for instance, I often found would take a paste made of brown bread when one of white was not touched. 
Chub-fishing is Piscator's first lesson to Venator in practical angling. It is evidently a bit of personal experience, probably near Amwell Magna, on the Lea, a portion of that fishful stream in which chub still abound. The description is perfect, a word-picture of what every chub-fisher has often experienced when fishing in a stream where these handsome fish abound. The natural grasshopper, a bait often recommended by Walton, is often far more killing than a worm, and yet one nowadays rarely finds it used.

My father, the "Amateur Angler," first taught me to catch a trout or a chub by dapping with a blue-bottle fly, holding the rod over an alder bush or casting an artificial fly in a stream, and in return I, over five-and-twenty years after, showed him how to float a dry fly over a rising trout or grayling in Hampshire and Derbyshire. What delightful days I have had with him on our English streams, days the remembrance of which makes me hope the future may have many such in store! Of the nature of the chub, and the best baits to use at different seasons for him, Walton has left but little for later writers to add; and if this fish can be made into a decent dish of food, it must surely be by following his directions. 
"Observations of the nature and breeding of the Trout, and how to fish for him -and the Milk Maid's Song," is the heading of the much enlarged Chapter IV. of the fifth edition; perhaps the most interesting of all Walton wrote. He loved the trout above all fish, and held troutfishing in the greatest estimation. Among the varieties of this fish which he mentions none has caused more controversy than the famous "Fordidge Trout": his statements have been flatly contradicted by some of his editors. He says, -

"There is also in Kent near Canterbury a Trout (call'd there a Fordidge 'Trout), a Trout (that bears the name of the Town where it is usually caught) that is accounted the rarest of Fish ; many of them near the bigness of a salmon, but known by their different colour, and in their best season they-cut very white; and none of these have been known to be caught with an Angle, unless it were one that was caught by Sir George Hastings; and he hath told me, he thought that Trout bit not for hunger but wantonness, and it is the rather to be believed, because both he then, and many others before him, have been curious to search into their bellies, what the food was by which they lived; and have found out nothing by which 


\section{I70 The Fordwich Trout.}

they might satisfy their curiosity." . . Walton then states that this fish "knows his times (I think almost his day) of coming into that river out of the sea, where he lives (and it is like, feeds) nine months out of the year, and fasts three in the River of Fordidge. ... . You are to know that this Trout is thought to eat nothing in the fresh water."

So far Walton; now, in his excellent edition of The Compleat Angler, Dr. Bethune has this reference to Walton's Fordidge Trout :-

"Fordwich is about two miles east of Canterbury, on the river the Stour. Yarrell says, unhesitatingly, that the Fordwich trout is the salmon trout (Salmo trutta of Linnæus, Salmo albus or white trout, Flem, Brit. $A n$.), what is called the hirling in some parts of Scotland. He says also, in contradiction to Walton and his friend Sir George Hastings, that quantities are taken with the rod, and on being examined are found full of various insects, particularly the sand-hopper. The very rapid digestion of the salmon family led to our author's error."

This is a fair specimen of the manner in which Walton is flatly contradicted, and yet I feel certain that he is perfectly right and Yarrell wrong. I was for some years 
a member of the Stour Fishery Association, and have caught trout both above and below Canterbury. I have not been able to see a specimen of the fish Walton refers to ; but experienced salmon anglers living at Canterbury have, and they agree with me in thinking that the fish is the Bull Trout (salmo eriox) which ascends several of our south-coast rivers. This fish corresponds with Walton's description, and only very rarely in this river is one taken on a rod and line, and nothing is ever found in its stomach. If I am not mistaken, my late friend Frank Buckland was the first to identify Walton's Fordidge Trout with the Bull Trout, and his opinion on a point of that kind was second to none.

And yet another editor of Walton, "Ephemera" (Fitzgibbon), says the whole of Walton's account of the Fordidge Trout is a mere fable.

In fact, these editors of Walton who, generation after generation, impose upon themselves the task of correcting in footnotes his mistakes, or supposed mistakes, seem to:me to spend much labour in vain; for, as one of them remarks, "Very mucn of what Walton says the reader will at once see to be erroneous." Then why go to the trouble of correcting him, especially 
when the "corrections" are often more erroneous than the original?

To writers like "Ephemera" is due the vague impression which some anglers have who have not read Walton, that he was merely a bottom or live-bait fisher, and knew next to nothing of fly-fishing or spinning with a minnow. This statement is far from being correct. Again, both Walton and Cotton have suffered by the want of angling knowledge of their illustrators. Who does not remember the picture entitled "Landing the Grayling," which has appeared in so many editions of Walton, in which the angler is represented as catching hold of the line to pull the fish in? And yet over a century before this engraving was made Walton wrote thus :-

"Piscator. Look you scholar, you see I have hold of a good Fish: I now see it is a Trout, I pray, put that net under him, and touch not my line, for if you do, then we break all. Well done scholar, I thank you."

And Cotton, in the very incident depicted, makes Piscator Junior call out "Bring hither that landing net, Boy."

It is true, as I have previously mentioned, that Walton quotes Barker's directions for fly-fishing and fly-making "with- 
out much variation," as he tells us in his first edition; but it does not follow that he knew nothing about it himself. Cotton distinctly tells us " it would look like a presumption in me, and peradventure would do so in another man, to pretend to give lessons for angling after him [Walton], who I do really believe understands as much of it, at least as any man in England"; and he explains that it is the style of fishing necessitated by the very clear waters he fished in that he will describe. In another place he tells Viator he will give him some instructions how "to angle for a Trout in a clear River, that my Father Valton himself will not disapprove, though he did either purposely omit, or did not remember them, when you, and he sate discoursing under the Sycamore Tree."

"Ephemera" says how astonished IValton would have been could he have seen the artificial minnows and other baits made nowadays. Yes, he would indeed have been astonished; but if he wished to kill a dish of trout, I think he would still prefer that beautiful artificial minnow he so lovingly describes, "made by a handsome Woman that had a fine hand, and a live Minnow lying by her" to copy. His description of the way to make a natural or artificial minnow spin so that "a large 
I74 Walton and some Modem Baits.

trout will come as fiercely at it as the highest mettled Hawk doth seize on a Partridge, or a Grey-hound on a Hare," wants no improving.

It would, I think, be a good thing if in many ways we went back to the simplicity of Walton's directions in making up our tackles-spinning or other. I can fancy his astonishment if a modern "compleat angler" could show him the latest killdevil with great metal fans to spin it, and carrying from six to fifteen hooks; what would he as a sportsman say to the "automatic" and other inventions for taking fish which are so loudly advertised in this country and America, their chief merits-if their inventors are right-being that they give the fish "no chance"? Some are guaranteed to kill the fish by spring power, so that he cannot breathe, two springs made into hooks holding his jaws open.

With such tackle and baits Walton would never have killed that three brace of trout before breakfast ; but, on the other hand, he would never have had to make Piscator exclaim,-

"Oh me! he has broke all; there's half a line and a good hook lost.

"Venator. Aye and a good trout too.

"Piscator. Nay, the Trout is not lost, 


\section{Walton's Religion.}

for take notice no man can lose what he never had."

Then follow fly-fishing and fly-making; and it surely does not follow that, because Walton tells us he gives the directions of Barker and another first-rate fly-fisher, he knew nothing about it himself. It is clear to me that he was a good all-round angler, and was experienced in all the styles of fishing he describes.

The rest of this chapter is a most pleasant mixture of fishing and other lore and praise of nature and thanks to God; one very marked characteristic of Walton being that his religion is so purely and genuinely a part of himself that, though he brings it in at all sorts of odd seasons, it is never out of place and never offends. As Lowell says, "The reader of the Angler finds himself conscious of one meaning in the sixth Beatitude too often overlooked,- that the pure in heart shall see God, not only in some future and far-off sense, but wherever they turn their eyes."

"Piscator. And now, Scholar, my direction for the flie-fishing is ended with this showre, for it has done raining; and now look about you, and see how pleasantly that Meadow looks; nay, and the Earth smells as sweetly too. Come, let 
me tell you that holy Mr. Herbert says of such days and flowers as these, and then we will thank God that we enjoy them, and walk to the River and sit down quietly, and try to catch the other brace of trouts." And then he quotes Herbert's verses, -

"Sweet day, so cool, so calm, so bright, The bridal of the earth and skie, Sweet dews shall weep thy fall to-night, For thou must die."

Walton, in his Life of Herbert, tells us he had seen him, though he was not personally acquainted with him, and makes Venator say he "had heard he loved angling."

It was while sitting under the sycamore, as, he reminds us, "Virgil's Tityrus and his Melibæus did under their broad beechtree," that Walton says, -

"No life my honest Scholar, no life so happy and so pleasant, as the life of a well governed Angler; for when the Lawyer is swallowed up with business, and the Statesman is preventing or contriving plots, then we sit on Cowslipbanks, hear the birds sing, and possess ourselves in as much quietness as these silent silver streams, which we now see glide so quietly by us. Indeed my Good Scholar, we may say of Angling, as Dr. 
Boteler said of Strawberries, Doubtless God could have made a better berry, but doubtless God never did : And so (if I might be Judge) God never did make a more calm, quiet, innocent recreation than Angling."

Some few years ago, when we were wondering what few words we could put under the memorial of the late Francis Francis* in Winchester Cathedral, I suggested to Mr. Senior those italicised above, and these words from Walton are now engraved there.

Walton frequently refers to the trout and trout rivers of Hampshire. In one place he says :-

"Piscator. And you are to know that in Hampshire, which I think exceeds all England for swift, shallow, clear, pleasant Brooks, and store of Trouts, they use to catch Trouts in the night, by the light of a Torch or Straw, which when they have discovered, they strike with a Trout spear or other wayes. This kind of way they catch very many, but I would not believe it till I was an eye-witness of it, nor do I like it now I have seen it.

"Venator. But Master, do not Trouts see us in the night?

* For many years angling editor of The Field, author of $A$ Book of Angling, etc. 
"Piscator. Yes, and hear, and smell too, both then and in the daytime."

I have heard anglers doubt if fish have much if any sense of smell; but Walton was undoubtedly right, as any angler who is not careful to use fresh and sweet baits and ground-baits will discover. Chapter VI., a short one, is entitled "Observations of the Umber or Grayling and directions how to fish for them." It shows Walton was well acquainted with the habits of this fish, which is, he says, "very pleasant and jolly after mid-April," but "not to me so good to eat or to angle for" as the trout. Walton mentions that "he has been taken with a fly made of the red feathers of a Parakita"; in our day the "Red Tag" has slain its thousands of grayling, so it would seem a red colour has some special attraction for this fish, which is scented as of waterthyme, and the pupils of whose eyes are pear-shaped.

By the way, Walton's mention of Hampshire brooks reminds me that in the verses entitled "The Angler's Wish," which he tells Venator he made "when I sate last on this Primrose-bank," occur the lines,-

"Or, with my Bryan, and a book, Loyter long days near Shawford-brook." 
These verses appeared first in the third edition of the Angler, published in 166r. It has generally been assumed, and I have no doubt correctly so, that Shawford is short for Shallowford, the village on the Sow, near Stafford, where Walton owned a house and land which he left to the poor of Stafford. But we know that Walton was acquainted with Hampshire. I have just quoted a passage in which he tells us he had witnessed trout-spearing there by torchlight. This passage appears in the first edition, published in 1653 . Is it not just possible that the Shawford referred to is the village of that name near Twyford, on the Itchen, a little below Vinchester? I confess the probability is that Shallowford, near Stafford, is referred to, as he bought the farm in $1654, *$ and probably often visited it between that date and the time he wrote the verses referred to first published in $\mathrm{r} 66 \mathrm{I}$. However, I never pass Shawford, when fishing in the Itchen, without thinking of Walton.

Although he does not tell us so in so many words, we may gather from the text that the primrose bank on which the verses were composed was neither at Shawford nor Shallowford, but on the Lea

* By an error I have this as 1656 in the "Lea and Dove" edition of the Angler.- R. B. M. 
not far from Waltham Cross ; for he says : "When I had ended this composure, I left this place and saw a Brother of the Angle sit under that hony-suckle hedg (one that will prove worth your acquaintance). I sate down by him, and presently we met with an accidental piece of merriment, which I will relate to you; for it rains still." Then follows the amusing interlude of the discussions and disputes between the gang of gipsies and the gang of beggars, the latter deciding at last to refer their squabble for settlement "to old Father Clause whom Ben Johnson* in his Beggars-bush created King of the Corporation," who "was that night to lodg at an Ale-house (called Catch-her-by-theway) not far from Waltham Cross, and in the high-road towards London."

Although the reel is mentioned by Walton as used in salmon and pike-fishing (I have already referred to what Barker says about it), it is pretty clear that he did not use it when trout-fishing, or fishing in such a river as the Lea or Dove, or he would not have replied as he did to Venator, who exclaims, -

"Oh me, look you Master, a fish a fish, oh las Master, I have lost her!

"Piscator. I marry Sir, that was a good

* Fletcher, not Jonson. 


\section{Giving Hin the Rod. IS I}

fish indeed; if I had had the luck to have taken up that Rod, then 'tis twenty to one, he should not have broke my line by running to the rods end as you suffered him: I would have held him within the bent of my Rod (unless he had been fellow to the great Trout that is near an ell long, which was of such length and depth, that he had his picture drawn, and now is to be seen at mine Host Rickabies at the George in Ware), and it may be, by giving that very great trout the Rod, that is, by casting it to him into the water, I might have caught him at the long run, for so I use alwayes to do when I meet with an overgrown fish, and you will learn to do so too hereafter; for I tell you, Scholar, fishing is an Art, or at least, it is an Art to catch fish."

In the absence of any reserve of line on a reel, and with a rod which would float, Walton's advice is sound enough. Some correspondent of The Fishing Gazette, who had campaigned in Afghanistan, described how the native fishermen captured the heaviest fish in this way. Dr. Bethune says, "This bungling practice is condemned by Cotton, and should never be resorted to by any one who has a reel at his hand." Cotton had no chance of meeting with a great Lea trout, and Walton had no 
reel ; it would have been more " bungling," in my opinion, to let the fish break the line than to risk rod and line, as he did in order to have a good chance of killing it.

Chapter VII. treats of "The Salmon, with directions how to fish for him."

Although erroneous in some particulars, Walton's general description of the habits of the salmon is very good. If his knowledge of actual fishing for this fish was confined to the Trent and Thames, his observation that baits are better than flies still holds - at least of the Trent, for the Thames has long ceased to produce salmon. Fly-fishing for Trent salmon has often been tried, but almost, if not quite, unsuccessfully. Here is Walton's reference to the use of the reel. "Note also, that many use to fish for a Salmon with a ring of wire on the top of their Rod, through which the Line may run to as great a length as is needful when he is hook'd. And to that end, some use a wheel about the middle of their Rod, or near their hand, which is to be observed better by seeing one of them, than by a large demonstration of words."

Chapter VIII. contains "Observations. of the Luce or Pike, with directions how to fish for him."

For no statement has Walton been more 
ridiculed than for saying that some pike are bred of a weed called Pickerel-weed, and yet the statement is not his; he merely says it is so "unless learned Gesner be much mistaken." His description of the nature and habits of this fish is excellent, and his stories about it, both native and foreign, most interesting, and quite equal to the best of our modern fish tales. His directions for killing pike with a live bait might be followed with advantage by keepers on trout preserves where pike have to be kept down. As Dr. Bethune says, "Walton understood the pike well."

Chapter IX. deals with the carp and " how to fish for him." Here, again, one of Walton's fish stories-i.e., that of the carp being killed by the frogs - has proved to be a true bill, full details of such killing being given a few years ago in the colunns of Die Deutsche Fischerei Zeitung. IValton rightly calls the carp "a stately, a good, and a very subtil fish." In some rivers and in some ponds I have experienced the truth of his statement that the carp is "very hard to take" ; in others he bites freely enough at any of the many excellent baits given by Walton, who, among other "tips," mentions the advantage of putting a bit of scarlet cloth soaked in Oyl of Peter, called by some Oyl of the Rock, on 
I84 A Wrinkle for Dry-Fly Anglers.

the hook with the bait. If he did not invent it (and no one dare claim to invent anything nowadays), at any rate, dry flyfishers have to thank Mr. Thomas Andrews, the celebrated pisciculturist of Guildford, for publishing the plan of oiling your fly with petroleum, or Oyl of Peter as Walton calls it. I have constantly proved its efficacy in keeping the fly dry, and am inclined to agree with Walton that fish rather like the smell of this oil. Mr. Andrews' plan - and I have found it answer admirably - is to carry a little oil in one of those small thick glass ink-bottles with inverted neck which prevents spilling. Have a small camel's-hair brush fixed into the bottom of the cork, so that when you remove the latter you have oil on the brush ready for use. The bottle can be suspended inside your creel, or from a button of your fishing-coat. N.B.-The fly floats better after the first few casts, and well-hackled flies answer best, of course. It is a tip which has done much to put the duffer at dry fly-fishing on a level with the expert on the point of allviz., keeping your fly floating on, and not half-drowned in, the water. There is one of Walton's recipes for making a carp bait which some nights recently I heartily wished might become popular-viz., "Take 
Did Walton Keep a Horse? IS 5

the flesh of a cat cut small and bean flour, and beat them together in mortar with sugar or honey, etc."

Observations of the Bream, and directions to catch him" occupy Chapter X.

Of the truth of most of Walton's observations about carp, bream, tench, etc., I have had personal experience, having for many years possessed a deep pool of from two to three acres well stored with these fish. Walton says that "Bream breed exceedingly in a water that pleases him; yea, in many Ponds so fast, as to over-store them, and starve the other fish." This I found to be the case with my bream.

Walton lived in the centre of London, and had some distance to go before he could fish in the Lea near Waltham, or Hoddesdon, or Ware. He could not go by train or tram or 'bus, as the modern Londoner does. He could not walk; at least, if he did, he got little time for fishing. $\mathrm{He}$ could do it comfortably if he kept a horse; and from a word or two let drop by accident in this chapter on bream-fishing I conclude he did keep a horse. In the midst of some directions for bream and carp baits and fishing, which have never been improved upon, among other things he tells Venator to " take a peck, or a peck and a half of 
I86 The Cunning of Bream.

sweet gross-ground barly-malt, and boil it in a kettle (one or two warms is enough); then strain it through a Bag into a tub (the liquor whereof hath often done my Horse much good), and when the bag and malt is near cold, take it down to the water-side about eight or nine of the clock in the evening, and not before; cast in two parts of your ground bait, squeezed hard between both your hands; it will sink presently to the bottom, and be sure it may rest in the very place where you mean to angle; if the stream run hard or move a little, cast your Malt in handfuls a little the higher, upwards the stream. You may between your hands close the Malt so fast in handfuls, that the water will hardly part it with the fall.

"Your ground thus baited, and tackling fitted, leave your bag with the rest of your tackling and ground bait near the sportingplace all night, and in the morning about three or four of the clock visit the waterside (but not too near), for they have a cunning Watch-man and are watchful themselves too."

I have quoted more than I intended to, but the whole paragraph is very interesting to any one who cares about bream, carp, or tench-fishing, and it brings in Walton's horse. I have no doubt now that he used 
to ride out to his fishing and put up his horse at Host Rickabie's at the George in Ware, or at some other of those convenient inns near the river of which he has given such pleasant pictures.

In this chapter he tells us that he has often taken a pike a yard long on his bream hooks, but sometimes "he [the pike] hath had the luck to share my line." So he advises trying with a live bait at a baited spot like this, to get rid of any pike or perch which may be in the swim.

Dr. Bethune, most careful of annotators, evidently took this latter part of Chapter X. to be written by Walton. There is some doubt in my mind as to how much was quoted from that "most honest and excellent Angler" mentioned on page I 79 of the fifth edition, and whose initials, B. A., are added at the end of the chapter.

Chapter XI. is a short one on the tench, a fish which Walton tells us "I have not often angled for"; but the baits he recommends I have found to be excellent. The perch, in Chapter XII., and the eel, in Chapter XIII., are well dealt with. Walton gives a quaint reason for being inclined to believe that eels which are bred in rivers connected with the sea never return to fresh water when they have once tasted the salt water, " because I am certain that 
powdered [i.e., salted] Beef is a most excellent bait to catch an eel." In Chapter XIII. the lamprey, flounder, char, guiniad, etc., are briefly referred to. The barbel, as it deserves, has a chapter to itself, for it "affords an Angler choice sport, being a lusty and a cunning fish: so lusty and cunning as to endanger the breaking of the Angler's line, by running his head forcibly towards any covert, or hole or bank : and then striking at the line to break it off with his tail (as is observed by Plutarch, in his book De industria animalium), and also so cunning to nibble and suck off your worm close to the hook and yet avoid the letting the hook come into his mouth." It would be difficult to find fault with Walton's directions for fishing for barbel, or for roach, dace, and other and smaller fry, which complete the practical portion of his "Discourse" with Venator. I remember, when I first read them many years ago, being greatly struck with one of his methods of taking roach, and have often found it to be not only a deadly but also a very interesting one :-

"In many of the hot months, Roaches may also be caught thus: Take a Mayflie, or Ant-flie, sink him with a little lead to the bottom, near to the Piles or Posts of a Bridg, or near to any Posts of a 
Weire,-I mean any deep place where Roaches lie quietly, and then pull your flie up very leisurely, and usually a Roach will follow your bait to the very top of the water and gaze on it there, and run at it and take it lest the flie should flie away from him. I have seen this done at Windsor, and Henly Bridg, and great store of Roach taken; and sometimes a Dace or Chub."

It is most interesting to see a great roach follow the fly up to the surface and "gaze on it," as Walton says.

Fishing-TACKLE MAKERS RECOMMENDED BL IVALTON.

In his first edition, page 228, Piscator says to Viator,-

"You must have all these tackling, and twice so many more, with which, if you mean to be a fisher, you must store yourselfe: and to that purpose I will go with you either to Charles Brandons (neer to the Swan in Golding-Lane); or to Mr. Fletchers in the Court which did once belong to Dr. Nowel the Dean of St. Pauls, that I told you was a good man, and a good Fisher; it is hard by the west end of Saint Pauls Church; they be both honest men, and will fit an Angler with what tackling hee wants." 
To this Viator replies,-

" Then, good Master, let it be at Charles Brandon's, for he is neerest to my dwelling, and I pray lets meet there the ninth of May next about two of the Clock, and I'l want nothing that a Fisher should be furnished with."

In the fifth edition Brandon and Fletcher are not mentioned, and this paragraph is altered thus :-

"And to that purpose I will go with you either to Mr. Margrave who dwells amongst the book-sellers in St. Pauls Church-Yard, or to Mr. John Stubs, near to the Swan in Golding-Lane; they be both honest men, and will fit an Angler with what Tackling he lacks."

At the end of the second part of the fifth edition I find this advertisement :-

"Courteous Reader,

"You may be pleas'd to take notice, that at the Sign of the Three Trouts in St. Paul's Church-Yard, on the North side, you may be fitted with all sorts of the best Fishing Tackle, by

$$
\text { "John Margrave." }
$$

This modest advertisement must have been invaluable to Margrave; it reads as if drawn up by Walton, who, by the way, has this interesting marginal note on page 
237, fifth edition: "I have heard, that the tackling hath been prized at fifty pounds in the Inventory of an Angler."

In another place a celebrated hookmaker is thus referred to:-

"Charles Kirby in Harp Alley in Shoe Lane, the most exact and best Hookmaker this nation affords."

\section{Of Fish-Ponds, and How to Order Them.}

This is one of the chapters added by Walton, and is acknowledged by him as being condensed from Doctor Lebault's Maison Rustique. Until fresh-water fish lost much of their value as food for the people of all classes-that is to say, until they were superseded by sea fish, much superior in quality and far more abundant - the making and ordering of fish-ponds was of great importance. 'The numberless artificial lakes and ponds which exist in England at the present day owe their origin in most cases to the great esteem in which fresh-water fish were formerly held, especially when our ancestors were Roman Catholics. In those days they understood aquaculture far better than we do, and did not allow their ponds and lakes to become mere mud-tanks, as is too often the case now. Walton says :- 
192 Neglect of Pond-Culture.

"You are to cleanse your Pond, if you intend either profit or pleasure, once every three or four years (especially some ponds), and let it lye dry six or twelve months, both to kill the water weeds, as Water-lillies, Candocks, Reate and Bullrushes, that breed there; and also that as these die for want of water, so grass may grow in the Ponds bottom, which Carps will eat greedily in all the hot months if the Pond be clean."

It is a pity that our landowners of the present day pay so little attention to their ponds and lakes-often for generations they are left untouched, until they hold more mud than water, and are unwholesome for both land and water animals. If they were drained every few years, the mud put on the neighbouring fields, the bottom ploughed and sown with oats, and then used again for breeding fish, they would prove much more profitable than at present. Our farmers forget that the Jews in our large towns are always ready to buy carp and other fresh-water fish with scales : all fish, including eels, have scales; but the Jews will eat only those which have their scales in evidence.

It is also a pity that our farmers do not know that a permanent stream of water running through their land may often be 


\section{Sewage Farms and Trout Streams. 193}

converted into a small gold-mine. A thousand trout fry may be purchased for $£_{5}$, and if kept for two years will sell for $£ 50$-in fact, I have often paid at the rate of two shillings each for them. It is a mistake, also, to suppose that trout will not thrive in still ponds, if the latter are kept clean. I always feel sorry for a trout when I see him lying in a few inches of water, with perhaps two or three feet of mud under him instead ot the bright gravel he loves so well.

Water from a sewage farm or from sewage-precipitating works ought not to be allowed to flow into our streams. It is quite true fish will live in it, but it is equally true that it causes a rank and noxious growth of flannel and other weeds, and covers the gravelly bed of the stream with a coating of slime. It does not appear to injure the eggs of the coarse fish, roach, dace, etc., as weeds are their natural birth-places, and they hatch out in a few days; but trout eggs are utterly destroyed, buried under this vegetable slime, long before their hatching period has arrived. It stands to reason that, however clear it may look, sewage water is liquid manure, and as such ought to. be turned on to the land-not into the water. 
To make his work still more " compleat," Walton added to his third and subsequent editions an interesting "Short Discourse by Way of Postscript, touching the Lawes of Angling." Who the writer was is unknown, but he was evidently some learned legal angling friend of Walton, who warmly acknowledges the advantage he has had both from The Compleat Angler and the friendship of its author.

One last quotation from Walton's last chapter :-

"Venator. Well Master, I thank you for all your good directions, but for none more than this last of thankfulness, which I hope I shall never forget. And pray let's now rest ourselves in this sweet shady Arbour, which Nature herself has woven with her own fine fingers ; 'tis such a contexture of Woodbines, Sweetbrier, Jessamine, and Mirtle; and so interwoven, as will secure us both from the Suns violent heat; and from the approaching shower, and being sate down I will requite a part of your courtesies with a bottle of Sack, Milk, Oranges, and Sugar; which all put together, make a drink like Nectar."

A full glass to you, Master! And may your memory ever be as sweet as "this sweet shady Arbour" of "Woodbines, Sweetbrier, Jessamine, and Mirtle"! 


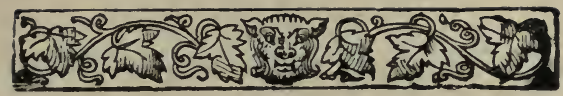

\section{CHAPTER XI.}

Some Notes on Charles Cotton's Practical Directions in Trout and Grayling-Fishing-Fish Fine and Far Off-Cotton the First Exponent of Clear-Water Fishing for Trout and Grayling-Yorkshire Fly-Rods - Pike PoolCreeper-Fishing First Described by Cotton, also "Swimming the Worm" for Grayling.

Charles Cotton's "Instructions How to Angle for a Trout or Grayling in a Clear Stream."

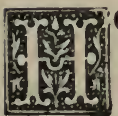

OW this second part of The Compleat Angler came to be written and published has already been noted. I shall here only refer briefly to its practical portions. If Walton was the father of general anglers, Cotton has even greater claims to be considered the first great exponent of clear-water fishing for trout and grayling. I have fished some of his favourite rivers, including the Dove, Derwent, Wye, Bradford, and Lath- 
kill, or Lathkin, as he calls it; and to appreciate his "Instructions" fully, it is necessary to do so ; in fact, it is a duty which every fly-fisher owes to his delightful art to make a pilgrimage to Beresford Dale, Dove Dale, and the other lovely dales and streams of this district. As Walton said in a marginal note on one of Cotton's pages,-

"The pleasantness of the rivers, mountains, and meadows cannot be described, unless Sir Philip Sidney or Mr. Cotton's Father were again alive to do it."

The scene of the "Instructions" is the little fishing-house.

"Piscator. Come Boy, set two Chairs, and whilst I am taking a Pipe of Tobacco, which is alwaies my Breakfast, we will, if you please, talk of some other Subject.

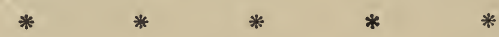

"Viator. I beseech you Sir, do, and if you will lend me your Steel, I will light a Pipe the while, for that is commonly my Breakfast in a morning too."

That Cotton had the confidence born of knowledge appears in his opening lines. "Piscator. Why then Sir, to begin methodically, as a Master in any Art should do (and I will not deny, but that I think myself a Master in this), I shall divide 
Angling for Trout or Grayling into these three ways,

$$
\begin{aligned}
& \text { At the Top, } \\
& \text { At the Bottom, and } \\
& \text { In the Middle. }
\end{aligned}
$$

Which three ways, though they are all of them (as I shall hereafter endeavour to make it appear) in some sort common to both those kinds of fish ; yet they are not so generally and absolutely so, but that they will necessarily require a distinction, which in due place I will also give you.

"That which we call Angling at the Top is with a Flie;

"At the Botton with a Ground-bait;

"In the Middle with a Minnow, or Ground-bait.

"Angling at the Top is of two sorts,

$$
\begin{gathered}
\text { With a quick (i.e., live) Flie, } \\
\text { or }
\end{gathered}
$$

With an artificial Flie.

"That we call Angling at the Bottom is also of two sorts,

$$
\text { By hand, }
$$

or

With a Cork, or Float. 
"That we call Angling in the Middle is also of two sorts,

With a Minnow for a Trout,

or

With a Ground-bait for a Grayling.

"Of all which several sorts of Angling, I will, if you can have the patience to hear me, give you the best account I can."

After this methodical outline Cotton proceeds to describe "Daping, Dabbing, or Dibling" with the natural fly-a fascinating style of fishing still carried on in many parts, notably with the drake on the Irish lakes, where numbers of very heavy fish are taken every May-fly season. On English trout preserves it is not as a rule allowed. In Hartington Mill-Dam I have often seen splendid trout "roving up and down to look for prey," as Cotton says, and doubtless he caught many a good fish there by "daping." He tells us that "many years ago" he had fished in this style with Walton, "one of the best Anglers that ever I knew." As regards fly-rods, he says: "The best that ever I saw are made in Yorkshire, which are all of one piece ; that is to say of several, six, eight, ten or twelve pieces, so neatly piec't, and 


\section{Yorkshive Fly-Rods.}

ty'd together with fine thread below, and Silk above, as to make it taper, like a switch, and to ply with a true bent to your hand; and these are so light, being made of Fir wood, for two or three lengths, nearest to the hand, and of other wood nearer the top, that a Man might very easily manage the longest of them that ever I saw, with one hand."

When fishing on that lovely trout and salmon river the Eden in Cumberland some years ago, I found spliced fly-rods of fir and lance wood were used by many of the anglers; and I had one made by a carpenter at Langwathby who had a reputation for them. It was not at all a bad rod.

As the length of these rods for troutfishing is not to be more than eighteen feet, it will be seen that fly-fishers of Cotton's time could, though no running line was used, command a good length of line,how much he does not say, except to note that, " to a Man that knows how to handle his Rod, and to cast, the length of the line is no manner of encumbrance, excepting in woody places, and in landing of a Fish, which every one that can afford to Angle for pleasure, has some body to do for him, and the length of line is a mighty advantage to the fishing at a distance ; and- 
To Fish Fine and Far OfF is the First and Principal Rule for TROUT-ANGLING.

Your line in this case should never be 'less, nor ever exceed two hairs next the hook, for one (though some I know will pretend to more Art, than their fellows) is indeed too few, the least accident, with the finest hand being sufficient to break it ; but he that cannot kill a Trout of twenty inches long with two, in a River clear of wood and weeds, as this and others of ours are, deserves not the name of an Angler."

The words I have italicised in the last paragraph give a standard of skill which any angler of the present day might be proud of, even with our advantage of running line and reel.

Walton acknowledges his indebtedness to Barker for his instructions in fly-making ; and the much more exact and admirable directions given by Charles Cotton were, he tells us on page $5 \mathrm{I}$ of his work, " taught me by a kinsman of mine, one Captain Henry Jackson, a near neighbour, an admirable Flie Angler, by many degrees the best Flie Maker, that ever I yet met with."

Here, then, is another angler-soldier of Walton's time to whom we owe some- 


\section{A Libel on the Grayling. $20 \mathrm{I}$}

thing. Cotton and Jackson were Royalists ; Colonel Venables and Captain Richard Franck were Cromwellian officers.

What I have never been able to understand is Cotton's calling a grayling "one of the deadest hearted Fishes in the World, and the bigger he is the more easily taken." I have killed a fair share of these beautiful fish in almost every grayling river in this country, and have often found them fight better than a trout, especially in the Test and the Costa. Certainly I have now and then caught a large grayling of $3 \mathrm{lbs}$. or more which seemed dazed, and instead of fighting rolled over and over helplessly into the net. But, then, who has not had the same experience with a good trout, hooked and got into the net before he realised the situation?

With the fine undrawn gut obtainable now we have a far stronger and less apparent means of presenting the fly to the fish than Cotton's double horsehair.

Page 50 of this original edition of Cotton is doubly interesting on account of its containing, not only references to Walton and his son, but also a marginal note by Walton himself.

Piscator Junior, in the course of his practical lesson in fly-fishing, brings his 
pupil Viator-who, be it remembered, is also the Venator of Walton's "Discourse" -to a scene on the Dove, which causes the visitor to exclaim,-

"Viator. But what have we got here? A Rock springing up in the middle of the River! This is one of the oddest sights, that ever I saw.

"Piscator. Why, Sir, from that Pike,* that you see standing up there distant from the Rock, this is call'd Pike-Pool; and young Mr. Izaac Walton was so pleas'd with it, as to draw it in Landscape in black and white in a blank Book I have at home, as he has done several prospects of my house also, which I keep for a memorial. of his favour, and will shew you, when we come up to dinner.

* Walton added this marginal note in smaller type: "'Tis a Rock, in the fashion of a SpireSteeple; and almost as big. It stands in the midst of the River Dove; and not far from Mr. Cotton's house, below which place this delicate River takes a swift Carere betwixt many mighty Rocks, much higher and bigger than St. Pauls Church, before 'twas burnt. And this Dove being oppos'd by one of the highest of them, has, at last, forc't itself a way through it; and after a miles concealment, appears again with more glory and beauty than before that opposition; running through the most pleasant Valleys and most fruitful Meadiows, that this Nation can. justly boast of." 
"Viator. Has young Master Izaak Walton been here too?

"Piscator. Yes, marry has he Sir, and that again and again too, and in France since, and at Rome, and at Venice, and I can't tell where : but I intend to ask him a great many hard questions so soon as I can see him, which will be, God willing, next month."

March 1676.$)$

(Cotton was writing in

An interesting fact, noted first, I think, by Cotton, is that the grayling may be taken in any of the cold months, especially during a frost. He tells us that he "did once take upon the sixt day of December one, and only one, of the biggest Graylings and the best in season, that ever I saw, or tasted . . . and have sometimes in January, so early as New Years-tide, and in frost and snow taken Grayling in a warm sunshine day for an hour or two about noon; and to fish for him with a grub it is then the best time of all."

The description of flies for use during the season given by Cotton is far ahead of anything which had appeared previously, and for long afterwards remained the standard authority to which fly-fishers referred. Any one who imagines that the flies used more than two hundred years 


\section{4 "Thirty Trouts and Graylings."}

ago were clumsy, large affairs should read Cotton's descriptions carefully : for instance, his dressing of "a very little bright Dun Gnat" on page 55. His chapter on the flies for May is particularly interesting -I mean, of course, to a fly-fisher. His natural history of the stone fly and green drake may not be quite correct in its under-water part, but as an account of what one sees of these insects after their first appearance on the water it is admirable. With an artificial May-fly, Cotton tells us that he once took, between five and eight in the evening, "thirty great Trouts and Graylings, and had no less than five or six Flies with three good hairs apiece taken from me in despite of my heart, besides."

Creeper-fishing in the streamy parts of rivers was first fully described by Cotton, who was also the father of clear-water worm-fishing. That now common expression "Snow Broth" I find first in his book. He, like all the writers of his time, complains bitterly of the poaching then carried on with impunity.

"I assure you, that with this very flie, I have in this very River that runs by us in three or four hours taken thirty, five and thirty, and forty of the best Trouts in the River. What shame and pity is it 


\section{Clear-Water Fishing. 205}

then, that such a river should be destroyed by the basest sort of people, by those unlawful ways of fire and netting in the night, and of damming, groping, spearing, hanging and hooking by day, which are now grown so common, that, though we have very good Laws to punish such Offenders, every Rascal does it, for ought I see impuné."

Cotton, when mentioning the number of fish he has taken, says "thirty Trouts," instead of "fifteen brace," and it appears at that time to have been the custom in the North to give the full number, and in the South to say so many brace, because in one place (p. 85), where Cotton makes Viator say, "Look you, Sir, here are three brace," Walton has added this note in the margin: "Spoke like a South-Country man."

Stewart and others have claimed for upstream, clear-water worm-fishing, that it is as artistic as, and more difficult than, fly-fishing; and although whole books have been devoted to this one branch. of the sport, I do not think that Cotton's directions have been, or can be, improved. upon. He may fairly claim to be the first to fully describe this fascinating style; he was also the first to note that grayling. take a worm swum a foot from the bottom 
with a cork much better than at the bottom-a style of fishing which Mr. Francis M. IValbran has made popular under the title of "Swimming the Worm." Keen, frosty weather is the time for it, and I hope to have some more pleasant days at it with him on some of Cotton's favourite north-country streams.

Note.-Since I wrote this chapter, in which Cotton's remark about the grayling being a deadhearted fish is referred to, I took a friend, a salmon and trout-angler, who had never canght a grayling, to the Test: his first fish was one of two pounds, which fought so well and so stubbornly that, when I turned every now and then from my fishing to watch his bending rod, I thought he would have no reason to call a grayling dead-hearted. Later on, among a few brace of good fish I killed, was one of two and a half pounds, which fought splendidly, compelling me to follow him forty yards down stream, and, for a time, spoil one of the best bits of water fishable in a wild November north-easter. I was so warm from the exertion of fishing and playing fish in such a gale, that I did not think of the weather till I noticed the blue nose of my friend the keeper, who was carrying my net: he shivered so that I sent him home.

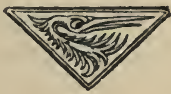




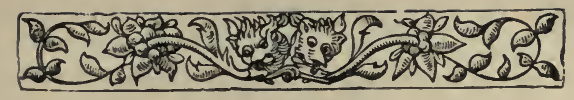

\section{CHAPTER XII.}

Some Editions of The Compleat Angler Subsequent to the Fifth-An Interval of over Seventy Years-Moses Browne's Reprints, 1750, 1759, and 1772-John Hawkins's Editions, 1760 to 1784 -The Bagster Edition, 1808-Gosden's Edition, 1822-John Major's Editions-One "Higgs" has a Copy Bound in Wood which he Cut from Cotton's FishingHouse-Some Notes on Major's EditionsHow Major Courted Immortality-Pickering's $32 \mathrm{mo}$, His Fine Edition of 1836 , the Result of Seven Years' Labour-Sir Harris Nicolas Walton's Best Editor-Some Account of Dr. Bethune's Edition-“"Ephemera's" Editions-A German Edition of Walton-Some other Editions, and a Welcome for a New One by Bagster.

Some Editions of "The Compleat Angler" Subsequent to the Fifth.

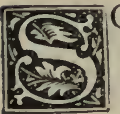

O far, in these random casts among the pages of Walton and Cotton, I have had before me copies printed in their time and for them, the very pages of which might have been seen by them. Indeed, as my 
copy of the fifth edition came from Stafford, it may be one given by Walton to some friend there. In I7 44 it belonged to a John Yeomans, who has written his name about it considerably, and in $17 \times 5$ added this warning :-

"John Yeomans His Booke 1715.

Steal not this Booke

for fear of shame

for hear y see

the onors name."

Although one may possess, as I do, copies of nearly all the hundred or more of editions of this little work, none can have such a charm for the reader as one of the first five: it adds so infinitely to the interest to know that this old-fashioned type and spelling was every word and letter of it seen by Walton and Cotton, and the collector will always value any one of these most highly.

It is somewhat curious that, although five editions of The Compleat Angler were called for between 1653 and 1676 , no other edition appeared, or at any rate is known, between that date and $175^{\circ}$, when Moses Browne edited a reprint of it, giving very poor copies of Walton's fish, but adding full-page illustrations by H. Burgh, some of which are, I think, 
very good, especially that of Trout Hall. The fishing-house must have been drawn from imagination. Browne was the author of Piscatory Eclogues, which contain some of the most poetical verses ever written in connection with angling, after those of J. D. There is plenty of verse about our art, but not too much poetry. Browne took the unpardonable liberty of correcting some of the "inaccuracies " and "redundancies" of the original, for which he has been mildly anathematised by Mr. Westwood in his Chronicle of "The Compleat Angler," to which work of more than a hundred pages I would again refer the reader who wishes to get full bibliographical descriptions of the various editions.

Here is a specimen of Browne's verse from an eclogue entitled "Renock's Despair." Renock, "a slighted swain," thus addresses his mistress :-

"O cold as morning dews, as inid-day bright,

And more than Primrose sweet, than daisywhite,

Softer than down that on the thistle grows, Which ripe September gives the frolic wind, And cruel as the thorn which arms the rose Must I unpity'd ever wail my woes,

Thy lips all pouting, and thy brow severe;

While scornful of my fate and abject pains, You, to my grief, withhold a soft'ning ear." 
Not content with making verbal alterations in Walton's text, and improving some verse which he correctly terms doggerel, he even tampers with John Dennys' fine lines quoted by Walton. Still, his edition has its merits, and his estimate of Walton and his work is so true and so well expressed as to make one regret all the more that he should have been so unwise as to attempt to "file off something of that Rust and Uncouthness, which Time fixes on the most curious finished Things." He added a well-compiled appendix of thirty pages, about rivers, haunts of fish, seasons, tackle, baits, etc.

Browne's editions of Walton were three in number : I750, I759, and I772. He was a friend of Dr. Johnson, who advised him to publish the work.

Between the second and third issues of Browne's editions, the first of a much more notable series appeared-viz., that edited by John Hawkins in I760. He dates the dedication of this edition at Twickenham, April roth, I 760 , and quite ignores Moses Browne-except to pat him on the back for his eclogues. He gave us the first reliable account of the authors. But, as I have pointed out at some length in my "Lea and Dove" edition of The 
Compleat Angler, it was to that indefatigable antiquary William Oldys, Norroy King-at-Arms, that we owe the principal facts about Walton and Cotton which have come down to us, and not to Sir John Hawkins, to whom they have been invariably credited. Mr. Thoms, when editor of Notes and Queries, was the first, I believe, to point out how much we owe to Oldys.

The illustrations of fish in Hawkins's edition, although better than Browne's, are still much inferior to those in Walton's first edition. The copper-plate full-page views of scenes described in the book were engraved by Ryland from designs by Wale. Browne complained, and not without justice, I think, that some of these illustrations came near being copies of those in his book. If S. Wale, Jun., had not seen the picture of the anglers lunching under the sycamore tree in Browne's edition, or that of the meeting between them and the milkmaid and her mother, it is difficult to account for the similarity: between his designs and those of Burgh. The plates of music are beautifully engraved in Hawkins, as one would expect from the author of $A$ History of Music, and he added some most useful engravings of tackle, including a winch, of 
methods of splicing rods, of aquatic insects, artificial flies, etc. He also added considerably to the "Short Discourse by way of Postscript touching the Laws of Angling," which was published first with the third edition of the Angler. He also gave in an appendix an extended list of flies and their dressings-some, I expect, from Bowlker. Above all, he reproduced Walton's text carefully. The first edition was printed for Thomas Hope, 1760 ; the second for J. Rivington, I 766 ; and the third for John and Francis Rivington, 1775 ; and, in 1784 , the last edition published during the lifetime of the editor, with some additions, was published by John, 'Francis, and Charles Rivington.

Passing over two further editions in the Hawkins series, published with a few notes by his son, we come to the first Bagster edition, I808. This, as Mr. Westwood says, is the "tallest" edition published up to that time. I have a fine copy of it before me. The illustrations are, as regards the fishing scenes, copies of those in Hawkins re-engraved by Philip Audinet, who also did the fish, which are for the most part a vast improvement on anything in Hawkins. With reference to these illustrations, the 
publisher, in a note dated $8 \mathrm{I}$, Strand, I808, says that those which were previously used are not copied from the old plates, but re-engraved from the original drawings of Mr. IVale; that "the sketch of Mr. Cotton's fishing-house, and the view of Pike-pool, having been found inaccurate, Mr. Samuel has favoured the publisher with a finished drawing of Pikepool, and a sketch of the fishing-house taken by himself on the spot in the year r799. Nor are the engravings of Fishes copied from the plates of any preceding edition; they are, in general, actual portraits of Fish which have been recently captured."

Portraits of Walton, Cotton, Hawkins, Wotton, Hooker, Herbert, and Dr. Donne are given; and in the Life of IValton some additional particulars are added on the authority of Dr. Zouch, who in 1790 had also published a Life.

This Bagster edition was in point of fact a reissue of Hawkins's with embellishments, the new view of the fishing-house being one of the best. It is an edition much prized by collectors, in its octavo, royal octavo, and quarto forms. One collector, whose name was Higgs, had a copy specially bound, the bands of the book being made with wood from the 
door of Cotton's fishing-house, taken off by Higgs near the lock, "where he was sure old Izaak's hand must have touched it." This copy afterwards sold for $£_{63}$. Walton's coffin would not be safe from some of his "admirers."

The second Bagster-Hawkins edition appeared in 1815 , with some notes by Sir Henry Ellis, of the British Museum, and new plates of fish. This edition was a great favourite with Mr. Westwood, being the first in which he read Walton. It was printed by $\mathrm{R}$. Watts, of Broxbourne, on the River Lea, Herts.

In 1822 Thomas Gosden reprinted Hawkins's edition with a new set of plates, which "did triple duty, they being offered for sale in a separate shape, and employed to illustrate the reprint of Zouch's Life of Valton, published by Gosden in 1823 , and subsequently." Mr. Westwood, I think, scarcely does justice to the illustrations in Gosden's edition. There is one of a group of fish from an original picture by Elmer " in the possession of the publisher," in which is one of the best illustrations of a trout ever published. The engravings of the fishing-house, of Beresford Hall, of Walton's house in Fleet Street, etc., are also excellent, and are certainly not "anachronisms," - if the same can be said 
of the fishing scenes. By notes and appendices the information of Valton was supposed to be brought down to date ; and I fail to see why, in introducing modern fishing scenes, or what were modern in I822, Gosden should be charged with inserting "anachronisms" scarcely in unison with the quaint character of the book. Indeed, from a picture of "King Charles II. in disguise in the Oak," published during Walton's lifetime, I am inclined to think that the ordinary everyday costume of the angler in his time was nearer to that of 1822 than as depicted by Burgh, for instance, in Moses Browne's edition.

Again, as regards the plates being used for more than one book, I fear most of the illustrations which have been made for most of the editions of Walton have been "hashed up" over and over again. Take the next "new issue" of the Angler -Major's, in I823. Major's illustrations have been constantly reprinted or copied, either wholly or in part, into new editions; which is certainly a compliment to Major, but somewhat disappointing to the collector.

While doing full justice to the beauty of Major's editions, especially that of $\mathrm{r} 844$, Mr. Westwood lashes him for his vanity 
in writing an essay on Walton. "In one passage he attempts to gloss over Walton's humble position in early life, and establish a claim for consideration, not so much on his own intrinsic merits, as on the ground of his high relations and fine acquaintances-a piece of snobbishness which draws on him the justly indignant rebuke of Dr. Bethune."

Major's first edition contained the old designs by IVale which had figured so often before- " greatly heightened in the effect by the pencil of Mr. Frederick Nash" and engraved by Cook and Pye-and very good woodcuts of fish. In his second edition (1824) the fourteen copper-plates were re-engraved by W. R. Smith. His third edition was in 1835 , and his last edition (i.e., the last issued by him) in 1844 . Mr. Westwood says of this edition: "It was printed, as before, in two sizes-crown and royal octavo. The obnoxious "Introductory Essay" still sticks to the work like a burr; but with this remark our censure exhausts itself ; in other respects the volume approaches more nearly to our ideal of an edition consistent in all its parts than any of its predecessors or successors. Wale's designs, repeated ad nauseam, are here suppressed, and a new series by Absolon substituted, embodying 
the same subjects, but conceived in no plagiaristic spirit."

Certainly the 1844 Major is an edition of Walton which every collector and lover of Valton is glad to possess. He tells us that "the new designs by Absolon form the crown of my present efforts." Absolon's nine drawings were engraved by J. T. Willmore, A.R.A. There are seventy-four woodcuts in the text, many of them being charming views of scenery by $\mathrm{T}$. Creswick, A.R.A. Major says in one place: "I had long been asking myself, in the language of Abraham Cowley, "What shall I do to be for ever known?' And my good Genius whispered, 'Give your days and nights to emblazon the worth of Izaak Walton.'" What would Major have said if he could have seen the numerous editions which have to thank his " emblazonments" for their existence-not always with acknowledgments to him ?

But between the first and fourth Majors appeared other editions of Walton, including Pickering's magnum opus, and an edition of which no trace can be found. This, Mr. Westwood says, is described in the London Catalogue, $1815-1832$, as a 6s. foolscap 8 vo reprint by Maunder in 1824. I would give something for an edition of Walton of which Mr. IVestwood 
could say all his efforts to obtain a copy had proved abortive.

Among the editions I have of Walton, one I prize greatly is the smallest of all, a little $32 \mathrm{mo}-$ Pickering's first edition in 1825. This wee volume, little more than three inches long, two wide, and half an inch thick, contains the whole of Walton and Cotton, uncumbered by notes. The type is small, but the whole goes into a watch-pocket, and my copy has travelled with me many thousands of miles.

But Pickering is not represented alone by the smallest Walton in existence. $\mathrm{He}$ gave us also in some respects the finest and most valuable, that of 1836 -the " result of seven years' continuous labour and of much patient research and fostering care on the part of its publisher." This edition is in two imperial 8vo volumes. The editor was Sir Harris Nicolas, the most indefatigable and careful editor that Walton ever had. What Sir Harris Nicolas has said leaves, as Mr. Westwood notes, "little in the way of data for any future gleaner in the same scanty field." "The illustrators are Stothard and Inskipp, the former being charged with the scenic plates and the views of the localities, and the latter, principally, with 
the fish." I confess I do not agree with the estimate of this edition formed by Mr. Westwood. He does not care for Stothard's illustrations, calls them unworthy of the book and of the artist, but admits that Inskipp's fish, "with some exceptions," display all the force and freshness of nature. I think that if you want Walton with editorial annotation developed to its utmost limits, with scenic and other illustrations to match, you must have this third edition of Pickering.

Among the American reprints of Walton, that of Dr. Bethune, first published in 1847 , is far and away the best. The Chronicle pays it this high compliment"For the lover of angling books, and for the collector especially, there is no edition so useful as this"; and quotes the following reference to it in Mr. J. Wynne's Private Libraries of New York:-

"During the darker seasons of the year, when forbidden the actual use of his rod, our friend has occupied himself with excursions through sale catalogues, fishing out from their dingy pages whatever tends to honour his favourite author and favourite art, so that his spoils now number nearly five hundred volumes of all sizes and dates. Pains have been taken to have, not only copies of the 
works included by the list, but also the several editions, and when it is of a work mentioned by Walton, an edition which the good old man himself may have seen."

Difficult, indeed, would it be to find anything in The Compleat Angler which has not been "annotated" in some form or other. In an "interview" with Mr. Harting about his forthcoming edition, I see he is made to say that Walton's mistake about the cuttle-fish, in confounding it with the "Angler" or "Devil" fish, has escaped notice. I think, if he refers to Dr. Bethune's edition, page 38 , he will find he is mistaken :-

"The cuttle-fish, which is not properly a fish, but of the class Mollusca, is confounded here with the Laphius piscatorius, common angler, toad-fish, sea-frog, seadevil."

Dr. Bethune's edition is certainly one which every collector should possess, not for its beauty of typography or illustration, but for the collection of information about Walton, and the "cordial, reverent and sympathetic" criticism of its editor. There have been several reprints of Dr. Bethune's edition. In 1880 a reissue appeared in New York by John Wiley \& Sons, in 2 vols., demy $8 \mathrm{vo}$, with this note :- 
"From the Publisher to the Reader.

"In putting forth this edition of Walton and Cotton, the original (Bethune) text of 1847 has been strictly adhered to, except where the marginal notes which Dr. Bethune added to his own private copy corrected an error, or added information which at the time of its first publication he had not acquired."

In 189 I Messrs. Ward, Lock, \& Co. reissued this edition in one volume.

In I853 appeared the first of the "Ephemera" editions of Walton. "Ephemera" was the nom de plume of Edward Fitzgibbon, for many years the angling editor of Bell's Life in London, and author of some excellent books on fishing. $\mathrm{He}$ was a thoroughly practical angler, and in piles of notes corrected and brought down to date the "Instructions" of Walton. His editions, first published by Ingram \& Cooke, and afterwards by Routledge, being cheap, have had a large sale.

\section{A German Eijtion of Walton.}

It is perhaps unfortunate that the edition of such an iconoclastic editor as. "Ephemera" should have been selected. 
for translation into the only edition of Walton into a foreign language that has appeared. "Ephemera" seems to have set Walton up in order to knock him down. $\mathrm{He}$ is like a good-humoured, but often irate, schoolmaster, "lecturing" a scholar for his mistakes, and then putting him right in a solemn and lengthy manner. His edition, with his voluminous notes, was translated into German by T. Schumacherr, and published in $\mathrm{I} 859$, with illustrations by P. Salomon \& Co., of Hamburg, under the title of

"Der Vollkommene Angler."

After a good deal of advertising in Germany, I succeeded in obtaining a copy, and find that, as well as "Ephemera's" notes, many of those by Sir John Hawkins are also translated, and some by the translator added. But what could a German reader be expected to think of Walton when the German publisher apologises for a "certain heaviness" in him "which could not be avoided in the translation," and the editor continually corrects the author in this style?-

"Dieser Kurze Paragraph enthält betrübende Irrthümer.

"Dieser Paragraph und der vorher- 
gehende sind mit blühendem und handgreiflichem Unsinn angefüllt."

The translation is evidently carefully, if not always correctly done, and that is all that can be said for it. It is commonplace and heavy. It was a bold undertaking to attempt to translate Walton. "Ephemera's" notes are admirably rendered, but all the spirit of The Compleat Angler is missing.

I give one or two specimens.

The CoMpleat

ANGLER.

Second Day.

"Ven. My friend Piscator, you have kept time with my thoughts, for the Sun is just rising, and I my self just now come to this place, and the dogs have just now put down an Otter. Look down at the bottom of the hill there in that meadow, chequered with Water-Lillies and Lady-smocks, there you may see what work they make; look, look! you may see all busie, men and dogs, dogs and men, all busie.
Der Volkoumene ANGLER.

Zweiter Tag.

"Ven. Mein Freund Piscator, unsere $\mathrm{Ge}$ danken haben sich gekreuzt, denn die Sonne ist gerade im Aufgehen begriffen, ich selbst bin erst eben angekommen, und in diesen Augenblicke haben die Hunde eine Ottergefangen. Blicken Sie hügelabwärts nach jener, mit Wasserlilien und Wiesenblumen besäten Wiese, dann werden Sie sehen, was schon gethan ist. Sehen Sie wie Männer und Hunde, Hunde und Männeralle thätig sind. 
"Pisc. Sir, I am right glad to meet you, and glad to have so fair an entrance into this dayes sport, and glad to see so many dogs, and more men all in pursuit of the Otter; lets complement no longer, but joyn unto them; come, honest Venator, lets be gone, let us make hast; I long to be doing: no reasonable hedg or ditch shall hold me."
"Pisc. Ich bien wahrhaftig sehr erfreut Sie getroffen zu haben, und einer so angenehmen Eröffnung der Jagd beizuwohnen, aber am meisten erfreut es mich, so viele Männer und Hunde in Verfolgung der Otter begriffen zu sehen. Lassen sie uns keine Zeit mit Reden verschwenden, sondern uns sofort der Jagd ansschlieszen. Kommen Sie, mein ehrenwerther Venator, beeilen wir uns, und machen wir, dasz wir fortkommen, ich sehne mich danach thätig mitzuwirken; keine Hecke, kein Teich soll uns aufhalten."

In German, Piscator requires far longer words and more of them to reply to Venator, who has, moreover, knocked all the spirit out of the thing by telling his friend that the dogs have caught the otter, whereas, of course, the sport had only just commenced.

Nearly all the verses in Walton are translated, with Coridon's catches and the milkmaid's songs, all in a straightforward and matter-of-fact, business-like manner. 


\section{Mr. Elliot Stock's Reprint. 225}

One verse of Herbert's lines will be enough :-

"Sweet day, so cool, so calm, so bright,

The bridal of the earth and skie;

Sweet dews shall weep thy fall to-night,

For thou must die."

“O ! kühler Tag, der heiter lacht, Als ob die Erde Hochzeit hab';

Es weint um Dich der Thau bei Nacht,

Du sinkst in's Grab."

There are some very pretty fishing scenes in the Walton edited by Jesse and published by Bohn in 1856 , with reprints in 1870 and 1876.

The Chronicle has, I am glad so see, a good word for the edition published by Bell \& Daldy and Low in 1863 , to which I have referred in the Introduction to this little volume. In 1866 and 1867 Messrs. Little, Brown, \& Co., of Boston, U.S.A., published a reproduction of the best of Major's editions, the I844. "The woodcuts were re-engraved for this edition, and are held to be finer than those employed in the English issue." 'The steel engravings are from the original plates. In I 876 Mr. Elliot Stock published a facsimile reprint of the first edition, published in 1653 . Seeing that it was published when photographic processes had not been brought to such perfection 
as at present, I think the illustrations hardly deserve the censure meted out to them in the Chronicle.

In r888 I brought out the "Lea and Dove" edition, being the hundredth edition of The Compleat Angler, in two volumes, small quarto, and a limited large-paper edition. My idea was to make illustrations of scenes on the rivers Lea and Dove the leading feature of this issue, and to give the text of the old classic in a style worthy, if possible, of its hundredth edition, and entirely unencumbered with notes. The text was printed from new type by Messrs. William Clowes \& Sons, Limited, who took the greatest interest in the work. The illustrations consist of about one hundred small woodcuts and fifty full-page photoengraved plates of views on the Lea and Dove-those on the Lea by Mr. P. H. Emerson, B.A., and those on the Dove by Mr. George Bankart. Possessors of this edition may at any rate rest satisfied that it will not be reprinted, as the copperplates I had transformed into boxes for keeping fly-books free from moth, and the type has been distributed. Of the reception of this edition both by the Press and the public I will only say that I was more than satisfied.

It is pleasant to note the number of 
editions of Walton which bear the imprint of American publishers, chiefly, of course, reprints of English editions or editions printed in England. The most beautiful edition we have had from America was one published in 1889 in two octavo volumes by Little, Brown, \& Co., of Boston (London, Macmillan \& Co.), with a small large-paper edition, of which I was glad to secure a copy, both because of the fact that it contains an "Introduction," extending to over fifty pages, by no less a writer than Mr. James Russell Lowell, and for the etchings by Harlow, which have been added to the illustrations from Major's edition of 1844 , with some fish by Inskipp from the great Pickering edition of 1836 . I must refer to Mr. Lowell's "Introduction" in another chapter.

Before closing these brief notes about some of the more prominent of the many editions of IValton, I must put in a word of welcome for yet another. I have received from Messrs. Samuel Bagster \& Sons, Limited, the prospectus of an édition de luxe of The Compleat Angler to be published shortly, "Edited, with Notes from a Naturalist's Point of View," by Mr. J. E. Harting, Librarian to the Linnæan Society of London, editor of The Zoologist, and author of many delightful works about 
birds. There are to be new illustrations of riverside animals and birds by Mr. G. C. Lodge ; also fifty illustrations by Percy Thomas. Two volumes, small quarto, of three hundred pages each. As already noted, Samuel Bagster's name as a publisher of editions of Walton is well known to collectors. I have some "tall copies" of them dated before this century was in its teens.

NotE.-In consequence of the "earthquake" mentioned in a previous chapter, I find I had omitted to mention an edition of Walton which all collectors onght to have: I refer to that edited by Captain H.J. Alfred, published by W. H. Allen So Co. in 1885, with copious notes by well-known members of the Gresham and other angling societies, etc. 


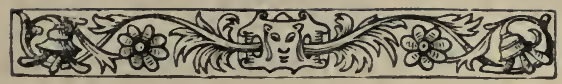

\section{CHAPTER XIII.}

Lines to Walton Published in 1619-Letters and References to Him by the Bishops of Chichester, Winchester, Lincoln, and the Archbishop of Canterbury-Sir Henry Wotton's Letter to Walton-The Commendatory Verses Prefixed to The Compleat AnglerDrayton and Ben Jonson-Dr. Johnson and Walton-An Extract from The American Review, 1830-Sir Walter Scott's Reference to Walton and Franck's Northern Memoirs - Some Extracts from James Russell Lowell's "Introduction" to an Edition of the Angler-Conclusion.

Some Contemporary and Subsequent OPINIONS ABOUT WALTON AND "ThE Compleat Angler."

"There are them that have left a name behinde them ; so that their praise shall be spoken of." Ecclus. xliv, 8.*

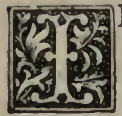

$\mathrm{N}$ the following pages I give a few of the many references to Walton and his work, which show in what esteem he has always been held both during and after his life.

* This quotation was placed by Walton on the title-page of his Life of Sir Henry Wotton, 
It is to Mr. J. Payne Collier we owe the discovery of the first reference to Walton. He pointed out, in his Poetical Decameron, that a short poem, entitled The Love of Amos and Laura, by S. P., published in 1619 , is dedicated thus :-

"TO MY APPROVED AND MUCH-RESPECTED FRIEND, IZ. WA.

"To thee, thou more than thrice-beloved friend,

I, too unworthy of so great a bliss,

These harsh-tun'd lines I here to thee commend,

Thou being cause it is now as it is ;

For had'st thou held thy tongue, by silence might

These have been buried in oblivious night.

"If they were pleasing I would call them thine,

And disavow my title to the verse,

But being bad, I needs must call them mine,

No ill thing can be clothed in thy verse.

Accept them then, and where I have offended, Rase thou it out and let it be amended."

The S. P. whose initials are attached to this poem is supposed to have been Samuel Purchas, author of The Pilgrimage, and other poems.

One of Walton's earliest friends in London was the celebrated Dr. Donne. $\mathrm{He}$ was his parishioner when Donne was sometime Provost of Euton Colledge, published by Richard Marriot in 1670. 


$$
\text { Dr. King's Letter. }
$$

vicar of St. Dunstan's, and it is probable that through him he was introduced to so many of the leading clergy and men of letters of his day. For instance, writing in the year 1664 , Dr. King, Lord Bishop of Chichester, thus addresses Walton.

EXtracts From the LetTers OF DR.

King, THE Bishop of Chichester, AND Other Churchmen to Walton.

"Honest IsAac, * - Though a familiarity of more than Forty years continuance, and the constant experience of your Love even in the worst times, be sufficient to indear our Friendship; yet, I must confess my Affection much improved, not only by Evidences of Private Respect to many that know and love you, but by your new Demonstration of a publick Spirit, testified in a diligent, true, and useful Collection of so many Material Passages as you have now afforded me in the Life of Venerable Mr. Hooker." . . .

The letter goes on to remind Walton that he was present at Donne's bedside three days before his death, to commend his Lives of Donne and Sir Henry Wotton,

* Both by his friends and himself Walton's name is written as "Izaak" and "Isaac." I have copied it as I found it. 
and to give him some information about the "ever memorable Mr. Hooker," and proceeds :-

"Lastly, I must again congratulate this Undertaking of yours, as now more proper to you than to any other person, by reason of your long Knowledge and Alliance to the worthy Family of the Cranmers (my old Friends also)..... And let me say further; you merit much from many of Mr. Hooker's best Friends then living, namely, from the ever renowned Archbishop Whitgift, of whose incomparable worth, with the character of the Times, you have given us a more short and significant account than I have received from any other Pen." ...

The Bishop signs himself:-

"One who heartily wishes your happiness, and is unfainedly, "Sir,

"Your ever-faithful and "Affectionate old Friend, "Henry Chichester.

"Chichester, November 17 th, I664."

In the same letter the Bishop tells Walton that "Mr. John Hales * (of Eaton College) affirm'd to me he had not seen

* "Our Bibliotheca ambulans" Sir Henry Wotton calls him. 


\section{Bishop Morley.}

a Life written with more advantage to the Subject, or more reputation to the Writer, than that of Dr. Donne's."

This testimony from an experience of "more than forty years" to the worth of IValton is written by Bishop King, and prefixed to the first collected edition of Walton's Lives of Donne, Wotton, Hooker, and Herbert, published in 1670 by Richard Marriot, and dedicated to Dr. George Morley, Bishop of Winchester. In the course of this dedication, Walton says that his Lives of Herbert and Donne were written under Bishop Morley's roof, and that if it has been possible for him to make his Lives "passable in an eloquent and captious age, it is by the advantage of forty years friendship, and thereby the hearing of and discoursing with your Lordship."

This, then, is another forty years' testimony.

In his "Epistle to the Reader" published with this I 670 edition of the Lives, Walton tells us that Doctor Gilbert Sheldon, afterwards Archbishop of Canterbury, had "twice injoyn'd" him to write the Life of Hooker. Dr. Sheldon was, he tells us in his Angler, a very skilful angler for barbel.

Sir William Dugdale, in his Short Viezo of the Late Troubles in England, refers to 
the "great judgment and integrity" with which Walton had compiled the Life of Hooker.

In his "Epistle Dedicatory" of his Life of Dr. Sanderson, Bishop of Lincoln, IValton, addressing Dr. George Morley, Bishop of Winchester, thanks him for having introduced him to "Dr. Sanderson, Mr. Chillingworth and Dr. Hammond," men whose merits ought never to be forgotten; and he mentions that his friendship for Dr. Sanderson "was begun almost forty years past."

The Bishop of Lincoln, dating his letter London, May roth, 1678 , thus addresses Walton :-

"My Worthy Friend Mr. Walton,I am heartily glad that you have undertaken to write the Life of that excellent person, and (both of learning and piety) eminent Prelate, Dr.Sanderson,late Bishop of Lincoln ; because I know your ability to know, and integrity to write truth."

After furnishing some particulars about Sanderson asked for by IValton, he concludes thus :-

"Pray pardon this rude, and I fear, impertinent scribble, which (if nothing else) may signify thus much, that I am 
willing to obey your desires, and am indeed

"Your affectionate Friend

"THOMAS LiNColN.

"Londox, May roth, Ió78."

We see from these brief extracts that Walton was personally known to, and beloved by,-

Dr. Henry King, Bishop of Chichester;

Dr. George Morley, Bishop of Winchester ;

Dr. Gilbert Sheldon, Archbishop of Canterbury ;

Dr. Robert Sanderson, Bishop of Lincoln;

Dr. Thomas Barlow, Bishop of Lincoln.

Sir Henry Wotton to His "Worthy FrIEND."

On February 27 th, 1672 , Walton wrote a dedication of the fourth edition of his Reliquia Wottoniane to the Right Honourable Philip, Earl of Chesterfield, who was a grand-nephew of Sir Henry Wotton, in which I find he says that two of his reasons for dedicating the work to his lordship were, -

I. "That Sir Henry Wotton, whose many merits made him an Ornament, even 
to your Family, was yet so humble, as to acknowledge me to be his Friend; and died in a belief that I was so.

2. "My other reason of this boldness, is, an incouragement (very like a command) from your worthy Cousin, and my Friend, Mr. Charles Cotton."

Among the Reliquice Wottoniance are "Letters to several Persons," including Lord Bacon, Milton, and Walton. In one "To Iz. Wa., In answer of a Letter requesting him to perform his promise of writing the Life of Dr. Donne," which is not dated, but from the closing lines was evidently written in the spring, Sir Henry Wotton says :-

"My Worthy Friend,-I am not able to yield any reason, no, not so much as may satisfie myself, why a most ingenuous Letter of yours hath lain so long by me (as it were in Lavender) without an Answer, save this only, The pleasure I have taken in your Style and Conceptions, together with a Meditation of the subject you propound, may seem to have cast me into a gentle slumber. But being now awaked, I do herein return you most hearty thanks for the kind prosecution of your rst motion, touching a just Office, due to the memory of our ever memorable 
Friend: To whose good fame though it be needless to add anything, (and my age considered almost hopeless from my pen;) yet I will endeavour to perform my promise, if it were but even for this cause, that in saying somewhat of the Life of so deserving a man, I may perchance over-live mine own.

"That which you add of Doctor King (now made Dean of Rochester, and by that translated into my native soil) is a great spur unto me; with whom I hope shortly to confer about it in my passage towards Boughton Malherb, (which was my genial Air) and invite him to a friendship with that Family where his Predecessor was familiarly acquainted. I shall write you at large by the next messenger, (being at present a little in Business) and then I shall set down certain general Heads, wherein I desire Information by your loving Diligence ; hoping shortly to enjoy your own ever welcome Company in this. approaching time of the Fly and the Cork. And so I rest

"Your very hearty poor Friend

to serve you,

"H. WotTon."

In another letter Sir Henry tells Walton. that since he last saw him he had been. 
confined to his chamber by a "quotidian Fever producing those Splenetick Vapours that are called Hypochondriacal; of which most say, the Cure is good Company ; and I desire no better Physician than yourself."

Among Wotton's poems in this collection are the pleasant lines quoted in The Compleat Angler, entitled "On a Bank as I sate a-Fishing," of which the first eight lines run,-

"And now all Nature seem'd in Love, The lusty Sap began to move;

New Juice did stir th' embracing Vines, And Birds had drawn their Valentines: The jealous Trout, that low did lie, Rose at a well-dissembled Flie : There stood my Friend, with patient skill Attending of his trembling Quill."

After pleasant wading through this thick volume of seven hundred pages, this is all I can find referring to Walton; but it is ample for my purpose. Sir Henry Wotton died in November 1639, before Walton had published anything except perhaps an elegy or two; and yet Walton must have been for many years before that his esteemed friend and angling companion.

The "Commendatory Verses."

It is somewhat curious that although 
The "Commendatory Verses." 239

the first edition of the Angler was published in 1653 , the second, published in 1655, contained commendatory verses from seven of Walton's friends not in the first, although one of these addresses, "To the Readers of my most ingenuous Friends Book, The Compleat Angler," written by Edward Powel, M.A., is dated April 3rd, $165^{\circ}$.

In these verses the writer refers to Walton's "matchless Lives of Donne and Wotton"; "but the latter was not published until 165 I, so that there appears to be a mistake in a date ; and yet "April 3 rd, I650," appears again with Powel's verses in the fifth edition in 1676 , and surely would have been corrected had it been an error of the printer.

Hear what these friends of Walton say in a few extracts from their lines :-

"To the Reader of 'The Compleat Angler.'

"First mark the Title well; my friend that gave it Has made it good; this book deserves to have it.

For he that views it with judicious looks, Shall find it full of art, baits, lines and hooks. The world the river is; both you and I, And all mankind, are either fish or fry:

If we pretend to reason, first or last

His baits will tempt us, and his hooks hold fast."

Ch. Harvie, M.A. 
Then follow some verses dated 1649 , addressed, "To my dear Friend Mr. Iz. Walton, in praise of Angling, which we both love," by Tho. Weaver, M.A.

"To the Readers of my most ingenuous Friends Book 'The Compleat Angler.'

"He that both knew and writ the lives of men, Such as were once, but must not be agen;

Reader, this $\mathrm{He}$, this Fisherman comes forth, And in these Fishers weeds would shroud his worth."

Edw. Powel, M.A., April 3rd, 1650.

"To my dear Brother, Mr. Iz. Walton, on his 'Compleat Angler.'

"This Book is so like you and you like it, For harmless Mirth, Expression, Art and Wit, That I protest ingenuously 'tis true, I love this Mirth, Art, Wit, the Book and You." RoB. FLOUd.

"Clarissimo amicissimoque Fratri, Domino Isaaco Walton, Artis Piscatoriæ peritissimo."

$$
\text { Henry Bayley, M.A. }
$$

"Ad Virum optinum \&. Piscatorem peritissimum, Isaacum Waltonum."

The first two lines of this long Ode run :-

"Magister artis docte Piscatoriæ, Waltone Salve, magne dux arundinis."

J. D. 
Drayton and Ben Jonson. 24I

Janes Duport, D.D., [Greek Professor at Cambridge, evidently an angler, as in another Ode to Walton he says,-]

"Næ tu Magister, et ego discipulus tuus,

(Nam candidatum \& me ferunt arundinis)."

I have given some other charming lines by Duport, written in a book he gave to Walton, among the "Waltoniana" of the "Lea and Dove" edition.

Sir Richard Baker, author of The Chronicle of the Kings of England, who refers to Dr. Donne and Sir Henry Wotton as " two of mine own old acquaintance," says, "The Trojan horse was not fuller of heroic Grecians, than King James's reign was full of men excellent in all kinds of learning."

From the brief extracts I have given, we see that Walton was the esteemed friend of some of the best of these contemporaries. He speaks of Drayton as his "honest old friend." He knew Ben Jonson, and at the end of some particulars about him which he gave Aubrey he says, "So much for brave Ben."

\section{Dr. Samuel Johnson and Walton.}

It is interesting and significant of Walton's worth as a writer, that the literary giant of the next century, Johnson, should 


\section{Dr. Johnson and Walton.}

have advised the publication of a new edition of The Compleat Angler, when that work had been out of print for nearly a century, also that he should have contemplated writing a Life of Walton.

Moses Browne, in the Preface to his edition of Walton's Angler, says he undertook it "at the invitation of a very ingenious and learned friend (Mr. Samuel Johnson), who mentioned to me, I remember, in that Conversation his Design to write the Life of Walton. I wish he had performed it." Boswell tells us that Johnson "talked of Isaac Walton's Lives, which was one of his most favourite books. Dr. Donne's Life, he said, was the most perfect of them."

Moses Browne gives his estimate of the book in these enthusiastic words :-

"Mr. Isaack Walton's Compleat Angler has been always had in greatest reputation, by such as are acquainted with Books, and have any Discernment, in works of Merit and Nature. And is so happy to have this which is very singular and uncommon to recommend it, that it has found the Way to make itself exceedingly agreeable to Readers of all Tastes, who have perused it. Not only the lovers of this Art, but all others that have least inclination to the Diversion it treats of, 
have join'd in giving it their mutual Commendation. . . . Its suitable unaffected Negligence and Simplicity of style, the hardest to imitate; and almost peculiar to himself, enlivened natural Descriptions, the many curious Discoveries (for its Time) in matters of philosophical and historical Science, the happiest mixture of religious and moral Instruction, enlivened with a vein of innocent Humour, and chearful entertainment appear in every page of it."

But it would be impossible to make note of all the references to Walton. D'Israeli, I remember, somewhere speaks of his "Doric Sweetness"; Wordsworth, of "Meek Walton's heavenly memory." Dr. Zouch, as Sir Harris Nicolas says, "has almost exhausted panegyric in his. praises of Walton."

From “The American Review," i 83o.

One of the most interesting references I have come across is the following, from the Life by Sir Harris Nicolas :-

"There is much that the admirers of Walton will read with pleasure in a criticism which appeared in The American Review of the Diary of Wilson, the ornithologist. Wilson says :-

"r8ro, April 25.-Breakfasted at 


\section{4 "The Doctrine of Pythagoras."}

Waiton's, thirteen miles from Nashville. The hospitable landlord, Isaac Walton, upon setting out early the next morning, refused to take anything for my fare; saying, "You seem to be travelling for the good of the world, and I cannot, I will not charge you anything; whenever you come this way, call and stay with meyou shall be welcome." This is the first instance of such hospitality which I have met with in the United States.'

"On this passage the American Reviewer observes :-

" "Upon reading this note, our faith in the doctrine of Pythagoras grew strong. Can it be that the soul of that gentle parent of the angle, old Izaak Walton, in winging its terrestrial flight from the margin of the sea, found a kindred tenement in mine excellent host of Tennessee ? We fear poor Wilson never luxuriated over the verdant pages of that golden book, The Compleat Angler, or he would have anticipated our passing tribute to its author. We too had, peradventure, died in ignorance, had it not been pointed out to us by the venerable author of The Man of Feeling, himself a brother of the gentle craft. We recall the era of the event as one of the greenest spots both in our literary and piscatory existence, and have 


\section{Sir Walter and Walton. 245}

ever since held it a settled maxim of our belief, in defiance of which we are ready to do battle, that no brother of the angle can by any possibility prove a recreant.'" *

Sir Walter Scott and Walton.

I daresay it would not be difficult to find a good many writers who, like Landor, gently scoff at Walton (see his "Imaginary Conversation" between IValton, Cotton, and Oldways), or, like his contemporary Captain Franck, who, in his Northern Memoirs, tells us he met Walton at Stafford, and that because he offered Walton a very probable natural solution of some supernatural statement he (IValton) had quoted from Gesner, IValton went off in a huff. To judge from his book, I should say it was far more likely Walton, if he was "huff'd" at all, was so by Franck's "affected pedantry" and "stupendous pretentiousness" There has been only one reprint of Franck's book (which was written in Walton's lifetime-in fact, in I658, though not published till $\mathrm{r}_{685}$, two years after Walton's death), and the author must have turned in his grave when the reprint was published; for its

* The American Review, No. xvi., December 1830, p. 376 . I wonder who was editor of The American Review at this time?-R. B. M. 
246 Sir Walter Scott's Wish.

editor, Sir Walter Scott, in his Introduction, says :-

"Probably no reader, while he reads the disparaging passages in which the venerable Isaac Walton is introduced, can forbear wishing that the good old man, who had so true an eye for Nature, so simple a taste for her most innocent pleasures, and withal, so sound a judgment, both concerning men and things, had made this northern tour instead of Franck; and had detailed in the beautiful simplicity of his Arcadian language, his observations on the scenery and manners of Scotland."

Revenge was the last thing Walton would care for; but what a revenge time brought for him! Here is the greatest genius of Scotland editing the only other edition of Franck's book ever published, and in the lines I have just quoted wishing Walton had made the journey and written the book. Still, one cannot help agreeing with Sir Walter that the gibes of Franck at "that scribbling putationer The Compleat Angler" are none the less pungent for having some substratum of truth in so far as they are the sarcasms of one who did know and practise fly-fishing for both salmon and trout, whereas Walton does not pretend to have done any salmon- 
fishing with the fly-rod-that, as Sir Walter calls it, "noble branch of the art, which exceeds all other uses of the angling-rod, as much as fox-hunting excels hare-hunting."

Franck insinuates more than once that Walton's book owes its popularity to its instructions how to cook fish rather than how to catch them ; in fact, he says plainly in one place that Walton's arguments would " beyond dispute have undubitably miscarried had not his wife had a finger in the pie."

\section{J. R. LOWELL'S "INTRODUCtion" to WALTON.}

The latest "Introduction" to an edition of Walton is one of the most important, as it contains the critical opinion of the man and the book by no less a writer than James Russell Lowell. I confess that the pleasure with which I read the announcement that the author of The Biglowe Papers was to write this very charming essay was not quite realised. In spite of much which every lover of Walton must re-echo, there are one or two things which seem to leave a somewhat unpleasant flavour in the mouth: this, for instance, referring to some men Walton 
knew, such as Carey, Brome, and Ben Jonson :-

"But these less reputable intimates he made welcome in a back-parlour of his mind, away from the street and with the curtains drawn, as if he would fain hide them even from himself."

Again : "Those must have been delightful evenings which the two friends [Walton and Cotton] spent together after the day's fishing. Well into the night they must have lingered with much excellent discourse of books and men, now serious, now playful-much personal anecdote and reminiscence. Perhaps it was as well that Dr. Morley should be at Winchester-with all respect be it said, and not forgetting that Walton has told us he 'loved such mirth as did not make friends ashamed to look upon one another next morning." "

Again, I can see nothing to make it an indication of a "lower love" that Walton "takes care to tell us that a certain artificial fly" (minnow it was) "was made by a handsome woman and with a fine hand."

Of Walton's style the critic says : "Walton, at any rate, in course of time, attained, at least in prose, to something which, if it may not be called style, was a very charming way of writing, all the more so that he has an innocent air of 
not knowing how it is done. ... No man ever achieved, as Walton sometimes did, a simplicity which leaves criticism helpless by the nere light of nature alone."

In another place, in referring to an account Walton gives of an accidental meeting with Sanderson, Mr. Lowell says, "It is exactly as if he were telling us of it, and this sweet persuasiveness of the living and naturally cadenced voice is never wanting in Walton. It is indeed his distinction, and it is a very rare quality in writers, upon most of whom, if they ever happily forget themselves and fall into the tone of talk, the pen too soon comes sputtering in."

His biographical work Mr. Lowell thinks "very delightful; and though more rambling than Plutarch, comes nearer to him than any other life-writing I can think of. . . . Never, surely, was there a more lovable man, nor to whom love found access by more avenues of sympathy. There are two books which have a place by themselves and side by side in our literature, Walton's Compleat Angler and White's Natural History of Selborne. . . . The purely literary charm of neither of them will alone authorise the place they hold so securely, though, as respects the Angler, this charm must be taken more largely into account. 
... They have this in common, that those who love them find themselves growing more and more to love the authors of them too. Theirs is an immortality of affection, perhaps the most desirable, as it is the rarest, of all. . . Both these books are pre-eminently cheerful books, and have the invaluable secret of distilling sunshine out of leaden skies. . . . If I must seek a word that more than any other explains the pleasure which Walton's way of writing gives us, I should say it was its innocency. It refreshes like the society of children."

I ought not to omit mention of the edition of Walton published at threepence in Cassell's " National Library," especially as the editor, Professor Henry Morley, LL.D., says, "There was but one Izaak Walton; and his book has an undying charm."

And here I must conclude this rambling little excursion among some old angling writers. I have cast my fly among their pages and the pages of those who have written of them ; and if my work has any value, it will be in the variety and interest of the extracts given. It is, as I said when commencing it, written, not for those who know Walton's writings, but in the hope that it may induce some who do not to 


\section{A Final Cast.}

become acquainted with them. I had intended to have referred at some length to the Lives, but have already exceeded the space at my disposal. One final cast before putting up my pen.

"There are no colours in the fairest sky So fair as these; the feather whence the pen Was shaped that traced the lives of these good Men,

Dropped from an angel's wing. With moistened eye,

We read of faith and purest charity,

In Statesman, Priest, and humble Citizen.

Oh! could we copy their mild virtues, then

What joy to live; what blessedness to die !

Methinks their very Names shine still and bright,

Apart - like glow-worms in the woods of spring,

Or lonely tapers shooting far a light

That guides and cheers-or, seen like stars on high,

Satellites burning in a lucid ring,

Around meek Walton's heavenly memory."

Wordsworth's Sonnet on Walton's Lives.

"It might sweeten a man's temper at any time to read The Compleat Angler."-Charles Lamb.

FINIS. 



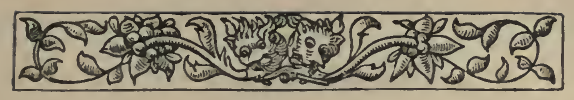

\section{N D EX.}

Adlington (W.B.), 35, 84 .

Afghanistan, Fishing in, 181.

Alfred's (Captain H. J.) edition of Walton, 228.

"Amateur Angler, The," and Walton's Angler, I21, 136, 168 .

American Izaak Walton, An, 244.

American Review, Interesting quotation from, 243.

Andrews (T.), I84.

Angler, Dennys' description of the qualities of a good, 80.

Angling, Invention and history of the art described by John Dennys, 74-79.

Arber's reprint of The Secrets, 68.

Archers, A note for, 83 .

Artificial flies, Dame Juliana Berners' list of, 22. Art of Angling, The, by Gervase Markham, 82.

Baker (Sir Richard), 241.

Barbel and roach, 188.

Barker's Delight, 91. See Barker (Thomas).

Barker (Thomas), a first-rate trout fisher, 9I253 
102 ; his Barker's Delight, 91; Walton's indebtedness to, 92 ; the first to describe the use of the reel and the gaff, 94 ; his instruction in salmon fishing, 95,96 ; his description of hackled flies and winged flies, 97.

Barlow (Dr. Thomas), Bishop of Lincoln, 235.

Bayley (Henry), M.A., 240.

Bentley (C. S.), F.S.A., and Barker's Delight, 93. Berners (Dame Juliana) and the Treatyse of Fysshynge wyth an Angle, 10-32; the Treatyse from an angler's point of view, 15; as an angling idyll, 26.

- and Mascall, 36 .

Bethune (Dr.), 170, 181, 183; his edition of Walton a most valuable one for the collector, an interesting notice of its editor, 219. Bibliotheca Piscatoria, The, 14, 34, 43, 59, 82, 90. Blades (William), 13. Blakey's (Robert), Angling Literature, I, 54, 56, 59.

Book of St.'Albans, The, I1, 53.

Bream, Tench, etc., 185 .

Browne (Moses), his edition of the Angler, 208, 209, 242.

"Broyled Trouts," 100.

Buckland (Frank) and the Fordwich Trout, 17 x.

Canna (La) de Piscare, 54.

Carp, 44, 88, 183.

"Cast of the Flie, The," first mentioned, 89.

Cheney (A. Nelson), 60. 


\section{Index.}

Chesterfield (Philip, Earl of), 235.

Chronicle of the Compleat Angler, by T. Westwood, 125, 139, 143, 209.

Clear water worm fishing, 205.

Collier (J. Payne), 230.

Cork, used in fly dressing, 86.

Cotton (Charles), and his part of The Compleat Angler, I 49; some account of his life, 149162; an accomplished angler, 153 ; his letter to Walton sent with his M.S., and Walton's reply, 154-157; Lowell's reference to, 158 ; Cotton's opinion of Walton, 159 ; his family affairs and death, 160-162; some notes on his practical directions in trout and grayling fishing, 195; a standard of skill, 200; his: libel on the grayling, 20I ; his references to "Young Master Walton," 203; the first to describe clear water worm fishing, 205.

Cranmers, Family of the, and Walton, 232.

Crayfish culture, 47 ; a great war among crayfish, 48 ; crayfish in the Stoke Newington

Reservoirs, 49.

Creeper fishing, 204.

Cromwell and Colonel Venables, 146.

Daniel's (Rev. W. B.) Rural Sports, 60.

Davy's (Sir Humphry), Salmonia, 64; patheticentry in his diary, 66.

Deluge of Deucalion, The, 74 .

Dennys' (John) Secrets of Angling, some account of the author and the book, 59-69; the Secrets compared with the Treatyse, 69,85 ; his "Pegasus" pattern of hook, 72; his. 
advice respecting the angler's dress, 72 ; extracts from his verses in praise of angling, 73 ; he traces its history from its invention by Deucalion through the ages, 74-79.

"Dobchicke, The," 50.

Donne (Dr.), 230, 23I, 236, 242.

Drayton (M.), $24 \mathrm{I}$.

Dry-fly anglers, A wrinkle for, 9I, I 84 .

Dugdale (Sir William), 233.

Duport (James), D.D., 24I.

"Dusted and put straight"! 123.

Editors of Walton and their "corrections" of him, 17 I.

Eels and salt beef, I87.

Eels, the, and the great frost of 1125,143 .

Egyptian goose feather, for May flies, 24.

Estienne's (Charles), L'Agriculture et Maison rustique, 36 .

Fish culture and Leonard Mascall, 34, 40, 43, $44,47$.

Fishing house, Walton and Cotton's, 105.

Fish-ponds, 191.

Fish spawn, to protect, $4 \mathrm{I}$.

Fishing-tackle makers recommended by Walton, 189.

Fitzgibbon's (Edward) edition of Walton, 22I. Floud, Rachel, Walton's first wife, IIO, II I. Fly-fishing for salmon, first mention of, $21,70$.

247. Sir Walter Scott's dictum respecting,

Fordwich trout, 169. 
Forer's (Dr. Conrad) edition of Gesner's great work on fishes, etc., $14 \mathrm{I}$.

Francis Francis, 177.

Franck's Northern Memoirs, 245.

Fraser's (Sir William) suggestion respecting the collar of $\Xi \lesssim$, 117 .

Gaff, use of, first described by Barker, 94 .

German edition of Walton, 22I-225.

Gesner (Dr. Conrad), I4I.

Good company, a cure for "splenetick "vapours, 238.

Gosden's reprint, 214.

Grayling, The, 178, 201, 206.

Groundbait, A good, 186.

Gryndall (William), 53 .

Harvie (Charles), M.A., 239.

Hawkins' (Sir John) editions of the Angler, 210. Henshall (Dr. James A.) and Walton at the World's Fair, 103.

"Herne," Mascall's directions for taking the, 38 . Higgs! 213 .

Illustrations, The, in the Compleat Angler, I 40,141 .

Invention of the art of angling, 76 .

“J. D.” (Sce Dennys, John), 59.

Jackson (Captain Henry), "an admirable flie angler," 200. 
Johnson's (Dr. Samuel) high opinion of Walton, 241.

Jonson (Ben), $24 \mathrm{I}$.

King (Dr. Henry), Bishop of Chichester, $23 \mathrm{I}$. "Kinges Fisher," Mascall's curious statement respecting the, 50 .

Lamb's (Charles) prescription for curing sour temper, 251. (See also 238.)

Landor (W. S.), 245.

Lawson (William), angler and writer, gives the best description of fly-fishing for trout previous to Barker, 84-9I.

"Lea and Dove" edition of Walton, 226, $24 \mathrm{I}$.

"Literary Blunders," 37, $\mathbf{1 3 2 .}$

Loach, The, 43.

Lowell, J. R., 27, 67, 158, I75, 227; his "Introduction" to an edition of The Angler, 247-250.

Mackenzie (Henry), author of The Man of Feeling, 244.

Major's (John) editions of Walton, 215; his ambition, 217.

Marbury's (Mrs. Mary Orvis) Favourite Flics and their Histories, 25.

Markham's (Gervase) Art of Angling, 6I, 8I .

Marston's (R. B.) Lea and Dove edition of Walton, 226, 24 r.

Martin (The Rev. William), Vicar of St. Dunstan's, and the proposed memorial to Walton, I14. 
Mascall (Leonard), 33-52, 85 ; his Booke of Fishing with Hooke and Line, 34.

Maunder's missing edition of Walton, 2 I 7 .

Michael Angelo, an angler, 53.

Millais, Sir John, 54 .

Miller's "Thumbes," 44 .

Morley (Dr. George), Bishop of Winchester, 233. Morley's (Prof. Henry) edition of Walton, $25^{\circ}$.

Mynherr Vandunk, 57.

Nelson " a good fly-fisher," 66.

Oldys (William), what we owe to him, 211 . Otter, Mascall's directions for taking the, 39.

"Parson of Culles, The," 45.

Patrick (Saint), and fish and snake stories, 4.

Pettie (John), R.A., 54.

Pickering's editions, his Magnum Opus, 217219.

Piers of Fulham, I.

Pike, Ior, 183 .

Pioneer of fish culture, 34 .

Pleasures of Princes, Markham's, 84 .

Plutarch's Lives compared with Walton's Lives.

249.

Poaching in Mascall's time, 46.

"Poult," eel-pout, or burbot, 43 .

Powel (Edward), M.A., 239.

Prime, Dr., 54.

"Proching Hooke," The, 37.

Protest, A, 64 . 
Purchas (Samuel), 230.

Pye, Mascall's "Pretie way to take a Pye," 5 I.

Pythagoras and Walton, 244.

"Red Hackle," History of the, 25.

"Red Spinner" (Mr. William Senior), 105;

presides at the Walton tercentenary celebration at Broxbourne, II4, I24.

Red tag, The, $\mathbf{1} 78$.

Reel, Use of, first described by Barker, 94 ;

Walton's reference to it, 95,180 .

- The multiplier, when first invented, 60.

Reliquice Wottoniance edited by Walton, 236.

Roach and barbel, I89.

Roe, Walton's angling companions, "Honest Nat. and R. Roe," 135 .

St. Mel (Bishop) ploughs fish out of dry ground, 7. Salmon, I82, 247.

Sanderson (Dr. Robert), Bishop of Lincoln, 234. Satchell (Thomas), 36.

Scott (Sir Walter) and Walton, 245-247; Sir Walter's dictum respecting fly-fishing for salmon, 247.

Secrets of Angling, The, 58-81.

Senior (William), 105, I 14, 124.

Sewage farms and trout streams, 193.

Shawford or Shallowford, 179.

Sheldon (Dr. Gilbert), Archbishop of Canterbury, a skilful angler, 233.

Snakes, How St. Patrick rid Ireland of, 7.

“ Southern corks," 88. 
Spider-dressed flies and winged flies, first described, 97.

Stafford, the Mayor of, and the Walton tercentenary, II3 ; meeting of Walton and Captain Franck at, 245.

"Stationers' Hall, Entered at," in 1612, 6r.

Stone fly, Old dressings of the, 85 .

Taverner's (John) Certaine Experiments Concerning Fish and Fruite, 53.

Treatyse of Fyshynge wyth an Angle. See Berners.

Trouler for pike, A famous, ror.

Trout-spearing by torchlight, 177 .

Venables (Colonel Robert), "experienc'd angler," 142 ; Walton's letter to Venables, I45; a short notice of Venables and his book, 146 .

Walbran (F. M.), 206.

Wallace (Sir William), fishing adventure of, 2. Walton (Izaak), a glance at the times he lived in, 106; brief biographical notice of, 107-120 ; his birth at Stafford, 107; early years in London, 108; was a member of the Ironmongers' Company, 109; what was his business? Iro; married to his first wife, Rachel Floud, III ; resides in Fleet Street, III; parish offices filled by him, II2; loses his wife and seven children during his residence in Chancery Lane, II5; six years later marries Anne Ken, 115 ; resides in I 8 
Clerkenwell, 116; instrumental in saving Charles the Second's collar of $\$ \delta$ after the battle of Worcester, II7; loses his second wife, lives at Winchester and Salisbury, I19, I79; dies at Winchester, and is buried in the cathedral, 120 ; his religion, I75; the memorial there, 120 ; proposed memorial of Walton in London, II3.

Walton's (IzaAk) Compleat Angler, The First EDItron, the amateur angler on his copy of the first edition, I2 I ; the first advertisement of the first edition, 122; the error in the first edition, 122 ; the "Dedication," I26 ; reproduction of title page of the first edition, 127 ; Walton's "Address to the Reader," I 29-135; secret of the charm of his book, I35; some past and present money values of a first edition, 136, 139. (See also pp. xvi.-xviii. of Introduction.)

The Second Edition (see also p. xvi. of Introduction); the illustrations, 139; an interesting discovery, I4I.

The Third and Fourth Editions, 143. The Important FifTH Edition, the last published in the author's lifetime, 144; Walton's letter to Colonel Venables, 145; Cotton asks Walton if he should supplement the Compleat Angler, 153; his letter to Walton sent with his MS., I54; Walton's reply, 156; Cotton's opinion of Walton, 159; an estimate of the influence of Walton's book, 163-166; it can never be antiquated, 165 ; 
the celebrated Fordwich trout, Walton riglit and Yarrell wrong, 169, 170; Walton and some of his editors, $17 \mathrm{I}$; did not use a reel, 180 ; " giving him the rod," I 81 ; did Walton keep a horse? 185 .

Walton's (IzaAk) Some Editions of the Compleat Angler subsequent to THE FifTH, 207-228; a seventy years' interval, 208; Moses Browne's editions, 208-210 ; Hawkins' editions, 210-213; the Bagster edition of 1808, 212 ; Higgs! 213; Gosden's reprint, 214 ; Major's editions, 215 ; Major's ambition, 217 ; Pickering's Magnum Opus, 217; a missing edition, 217 ; American editions, Dr. Bethune's, 219; the edition edited by "Ephemera" (Edward Fitzgibbon), 22I ; a German edition of Walton, 22I-225; some other editions, and yet another, 225-228.

Some Contemporary and Subsequent Opinions about Walton and the Compleat Angler, 228-251; lines to, by Samuel Purchas, published in 1619,230 ; letter from his "affectionate old friend," Dr. King, Bishop of Chichester, 231 ; his long friend. ship with Dr. George Morley, Bishop of Winchester, 233 ; also with Dr. Sanderson, Bishop of Lincoln, etc., 234, 235 ; letter to Walton from Sir Henry Wotton, 236 ; the "Commendatory Verses" to Walton, 238-24I; he knew Drayton and Ben Jonson, 24I ; Dr. Samuel Johnson's high opinion of his writings, 241 ; Moses Browne's 
pleasant estimate of his work, 242 ; references to, by D'Israeli, Wordsworth, and Dr. Zouch, 243 ; interesting. quotation from the diary of Wilson the ornithologist, 243; an American Izaak Walton, 244; Sir Walter Scott's estimate of, and wish respecting Walton, 246; some notice of James Russell Lowell's "Introduction " to an edition of Walton, and his opinions of the author and his writings, 247-250; Professor Henry Morley's edition of The Angler, 250; a final cast, $25 \mathrm{I}$.

Weaver (Thomas), M.A., 240.

Westwood's (T.) Chronicle of the Compleat Angler, 125, 139, 143, 209.

Wilson (the ornithologist), interesting extract from his diary, 243.

Winch. See Reel.

Wordsworth's sonnet on Walton's Lives, $25 \mathrm{I}$.

World's Fair, Chicago, Walton at the, I04.

Wotton (Sir Henry), 229, 231, 232, 235, 236, 238.

Yorkshire fly-rods, 199.

Zouch, Dr., 243.

Elliot Stock, Paternoster Row, London. 


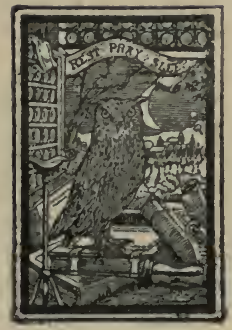


"The noblest gift-book that has been issued for many years."-St. James's Gazette.

The LEA and DOVE EDITION, being the 100th EDITION of

\section{THE COMPLEAT ANGLER.}

Edited by R. B. MARSTON,

Editor of the "Fishing Gazette"; Hon. Treasurer

of the Fly-Fishers' Club.

The principal feature of this Edition is a Set of 54 Full-page Photogravures, printed from Copperplates on fine Plate Paper, of Views on the Irea, Dove, Etc., and about 100 other Illustrations, all made for this Edition.

LARGE PAPER EDITION, in 2 Vols. Royal Quarto, bound in full-morocco, each copy numbered and signed, $£ 10$ 10s.

The DEMY QUARTO EDITION, bound in halfmorocco, gilt top, $£ 55 \mathrm{~s}$.

The whole of the type of this Edition has been distributed and the Full-page Copper-plates destroyed.

Very few copies of the Five-Guinea and only one or two of the Ten-Guinea Edition remain for sale.

From a long Review in the Times, Sept. 4th, r889:-

"The edition which celebrates the centenary of 'The Compleat Angler' is altogether worthy of the immortal work. Mr. Marston, the Editor of the Fishing Gazette, who is known as a 'deacon of the craft,' has grudged neither time, nor money, nor labour in perfecting these two magnificent volumes. The type and paper make a masterpiece of mechanical work, and the exquisite photogravures with which the volumes are embellished leave little or nothing to be desired."

"Never has Walton been more honoured. ... It will be one of the forms in which the work of Walton will be most coveted."-Standard.

"These sumptuous volumes."-Spectator.

"A truly magnificent edition."-Field. 


\section{Press Notices of the 100th Edition of "The Compleat Angler" (continued).}

"This noble edition,"-Daily News.

"So well graced a book will be in great demand among book collectors and anglers. It is the most desirable edition of Walton that has ever been offered to the public."-Scotsman.

"There are thousands upon thousands of anglers to whom the possession of such sumptuous volumes would be a lifelong joy ; but for most of them the work is too costly, and the edition is limited! Let us hope that the copies will fall into such hands only as Izaak Walton would have himself approved. They are 'a dish of meat too good for any but anglers or honest men,' and we can only hope that those who are fortunate enough to place these volumes upon their shelves 'will prove both." -Saturday Review.

"It is not merely the finest tribute yet paid to the wide and lasting popularity of Izaak Walton's book, but it is in itself a treasure of printing, binding, and illustration. To the reverent and loving care of $\mathrm{Mr}$. R. B. Marston, one of the partners in the publishing house, and a well-known master of the gentle art, this new issue, henceforth to be known as the 'Lea and Dove Edition,' is due. . . . Mr. Marston's introductory notes, while full of valuable information, are most pleasant reading, and the two volumes are a standing credit to all concerned in their production."-The World.

"A work by which the English printing industry and publishing enterprise of the later nineteenth century might well consent to be represented before the severest æsthetic tribunal of posterity. For clear-cut beauty of typography, for sober richness of binding and decoration, for lavish wealth and artistic excellence of illustration, it is a veritable triumph of the arts which have co-operated in its production. ... No more magnificent tribute has ever been paid to the name and fame of an English classic than this."-Daily Telegraph.

"This magnificent publication is second in interest to no predecessor in the long list of editions contained in the "Chronicle of the Compleat Angler." -Pall Mall Gazette.

"This admirable edition."-Morning Post.

\section{LONDON :}

SAMPSON LOW, MARSTON, AND COMPANY, LD., St. Dunstan's House, Fetter Lane, Fleet Street, E.C. 


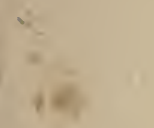





\section{THIS BOOK IS DUE ON THE LAST DATE}

STAMPED BELOW

AN INITIAL FINE OF 25 CENTS WILL BE ASSESSED FOR FAILURE TO RETURN THIS BOOK ON THE DATE DUE. THE PENALTY DAY AND TO TO 50 CENTS ON THE FOURTH OVERDUE.
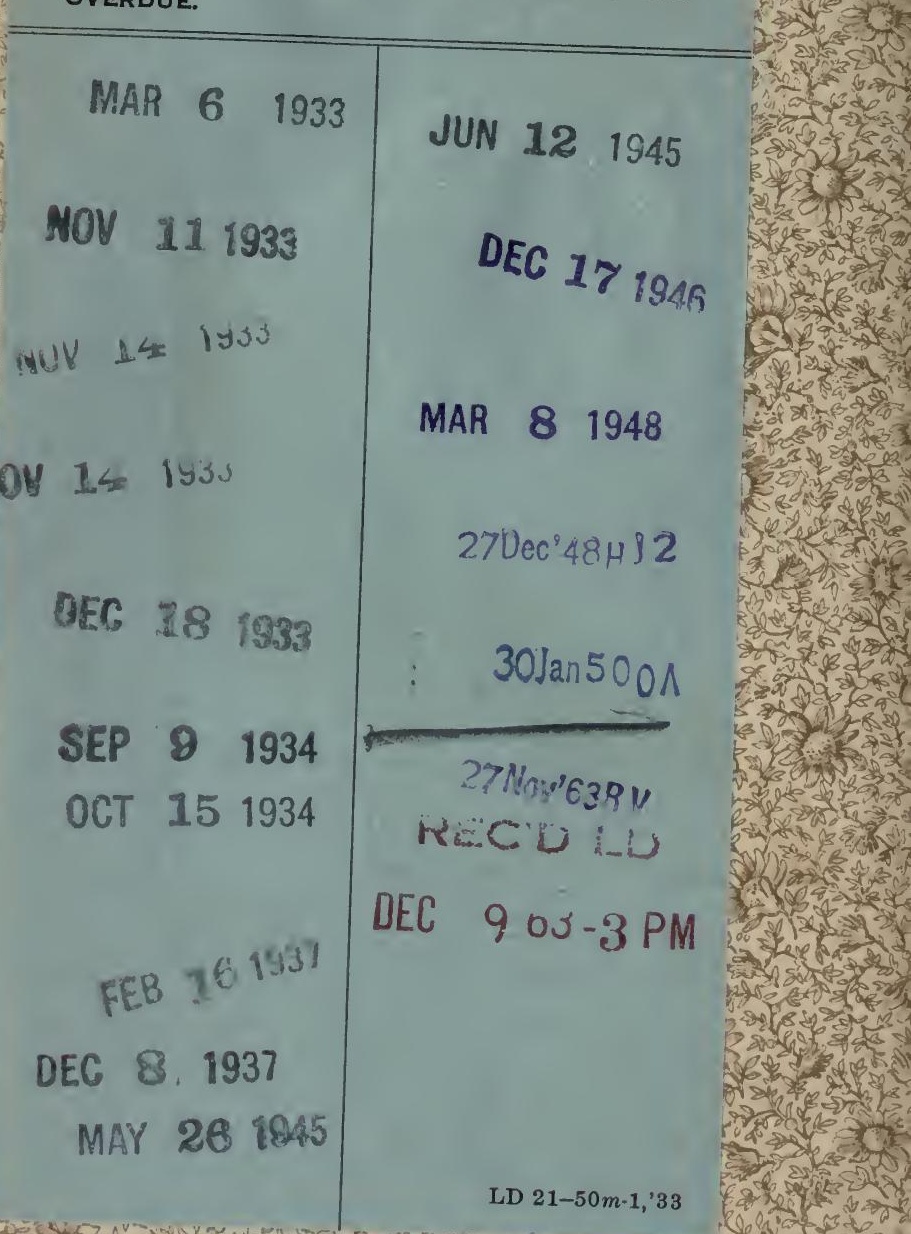

if 8 tostos स.

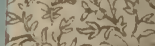
(2) 
IN YB 10624 wat

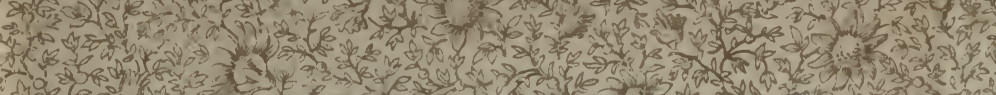
H.

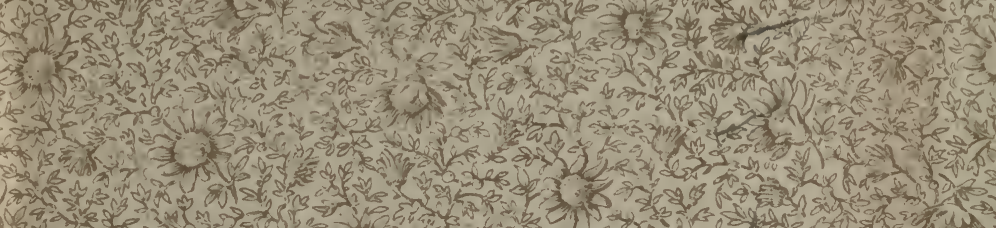
1. 1 .

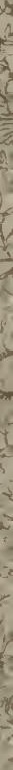
to

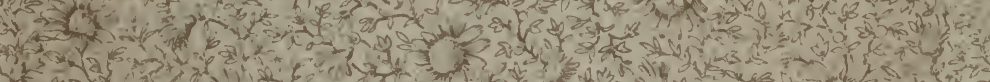

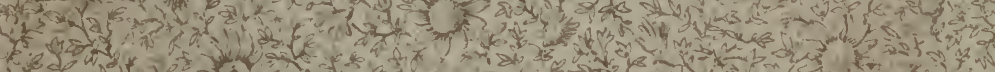

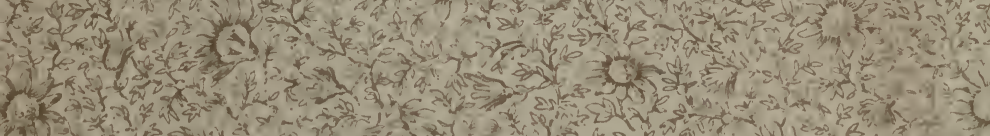
x t

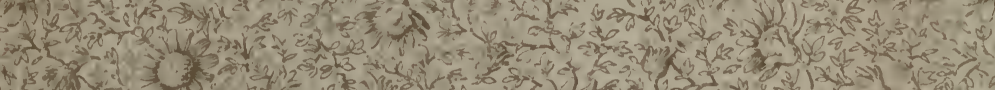

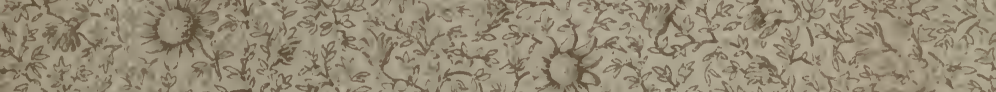
W (1) W. 
